Prepared in cooperation with the Virginia Transportation Research Council

\title{
Regional Curves of Bankfull Channel Geometry for Non-Urban Streams in the Piedmont Physiographic Province, Virginia
}

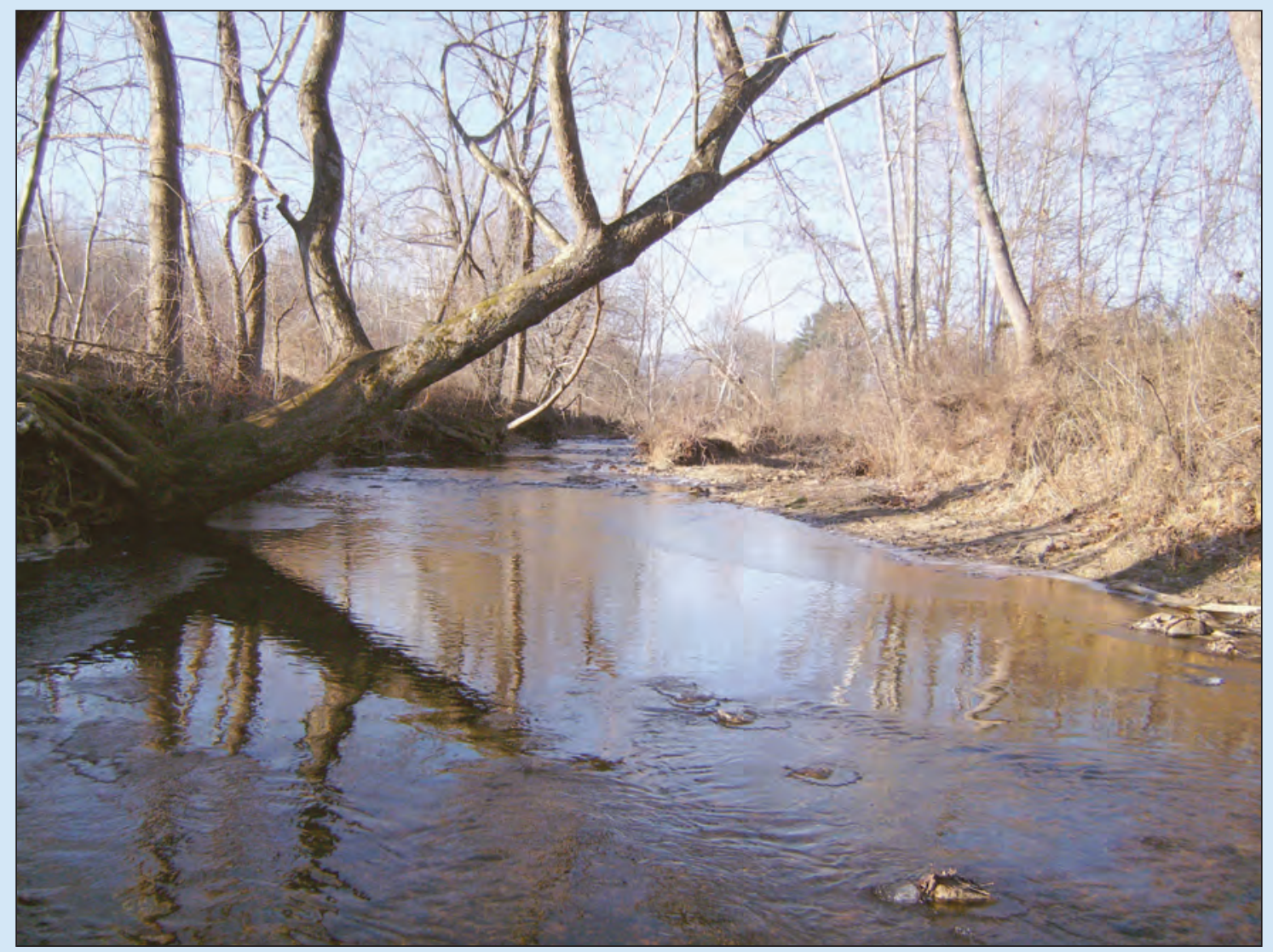

Scientific Investigations Report 2009-5206 
Cover. Smith River at Smith River Church near Woolwine, Virginia. View looking upstream from upstream cross section. (Photograph taken by R. Russell Lotspeich, U.S. Geological Survey, January 2, 2007.) 


\section{Regional Curves of Bankfull Channel Geometry for Non-Urban Streams in the Piedmont Physiographic Province, Virginia}

By R. Russell Lotspeich

Prepared in cooperation with the Virginia Transportation Research Council

Scientific Investigations Report 2009-5206 


\title{
U.S. Department of the Interior \\ KEN SALAZAR, Secretary
}

\author{
U.S. Geological Survey \\ Suzette M. Kimball, Acting Director
}

\section{U.S. Geological Survey, Reston, Virginia: 2009}

For more information on the USGS - the Federal source for science about the Earth, its natural and living resources, natural hazards, and the environment, visit http://Www.usgs.gov or call 1-888-ASK-USGS

For an overview of USGS information products, including maps, imagery, and publications, visit $h$ ttp://www.usgs.gov/pubprod

To order this and other USGS information products, visit http://store.usgs.gov

Any use of trade, product, or firm names is for descriptive purposes only and does not imply endorsement by the U.S. Government.

Although this report is in the public domain, permission must be secured from the individual copyright owners to reproduce any copyrighted materials contained within this report.

Suggested citation:

Lotspeich, R.R., 2009, Regional curves of bankfull channel geometry for non-urban streams in the Piedmont Physiographic Province, Virginia: U.S. Geological Survey Scientific Investigations Report 2009-5206, 51 p. 


\section{Contents}

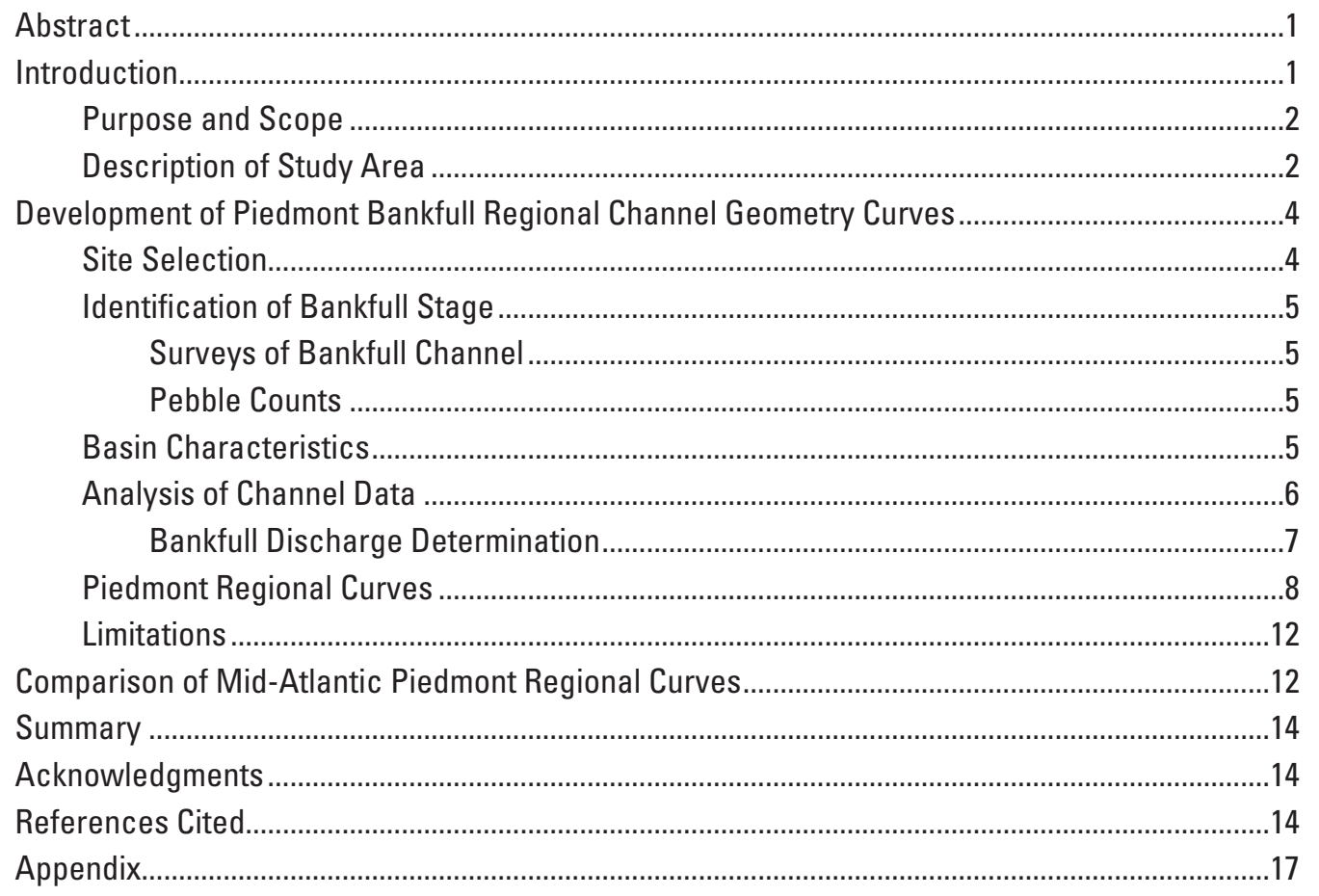




\section{Figures}

1. Map showing location of streamflow-gaging stations used for development of regional channel geometry curves in the Piedmont Physiographic Province in Virginia

2-7. Graphs for non-urban streams in the Piedmont Physiographic Province in Virginia showing -

2. Log-log plot comparing regressions of modeled and rated bankfull discharge to drainage area.

3. Regional curve relating bankfull cross-sectional area to drainage area .................8

4. Regional curve relating bankfull width to drainage area ........................................

5. Regional curve relating bankfull mean depth to drainage area ...............................

6. Regional curve relating bankfull discharge to drainage area ..................................

7. Regional curve relating bankfull slope to drainage area.........................................

8-12. Graphs showing regression residuals for regional curves-

8. Relating drainage area to bankfull cross-sectional area and box plot of the distribution of residuals for bankfull cross-sectional area ...

9. Relating drainage area to bankfull width and box plot of the distribution of residuals for bankfull width....

10. Relating drainage area to bankfull mean depth and box plot of the distribution of residuals for bankfull mean depth

11. Relating drainage area to estimated bankfull discharge and box plot of the distribution of residuals for estimated bankfull discharge.

12. Relating drainage area to bankfull slope and box plot of the distribution of residuals for bankfull slope

13-17. Graphs showing drainage area for streams in the Piedmont Physiographic Province in Pennsylvania, Maryland, Virginia, and North Carolina and-

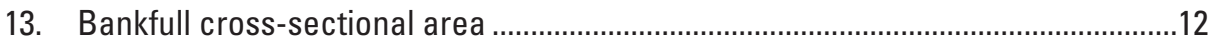

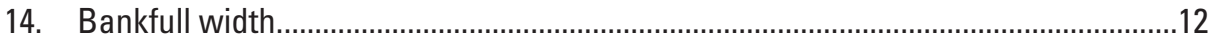

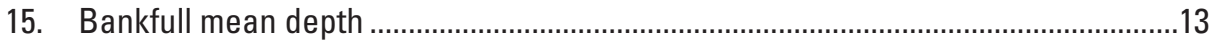

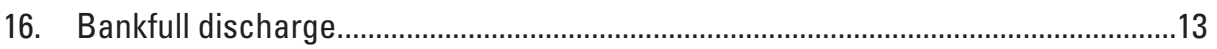

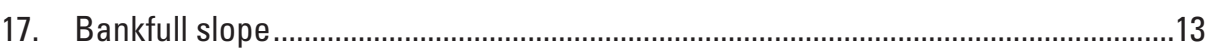


A-1 to A-17. Graphs showing longitudinal profile, riffle cross section, and particle size distribution of bed material, in study reach of -

A-1. South Fork Quantico Creek near Independent Hill, VA, November 7, 2007..............19

A-2. South Branch Chopawamsic Creek near Garrisonville, VA,

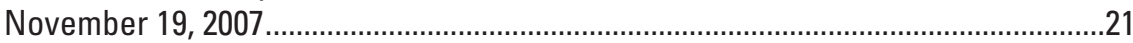

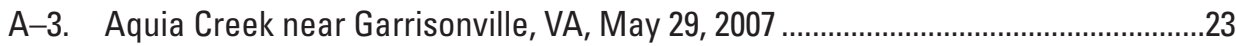

A-4. Contrary Creek near Mineral, VA, August 30, 2007 .............................................25

A-5. South Anna River tributary near Ashland, VA, June 2, 2008.....................................27

A-6. Buffalo River tributary near Amherst, VA, September 17, $2008 \ldots \ldots \ldots \ldots \ldots \ldots \ldots \ldots \ldots \ldots . . .29$

A-7. Mechums River near White Hall, VA, May 16, 2007..........................................31

A-8. North Fork Rivanna River near Earlysville, VA, May 18, 2007 .................................33

A-9. Big Lickinghole Creek tributary near Ferncliff, VA, September 22, 2008 ..................35

A-10. Fine Creek at Fine Creek Mills, VA, May 9, 2007 ................................................37

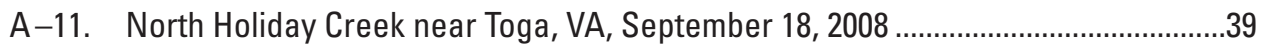

A-12. Buffalo Creek near Hampden Sydney, VA, March 10, 2008 .................................41

A-13. Falls Creek tributary near Victoria, VA, September 23, 2008 .................................4

A-14. North Meherrin River near Keysville, VA, June 13, 2007........................................45

A-15. Smith River at Smith River Church near Woolwine, VA, January 24, 2008...............47

A-16. Sandy River near Danville, VA, September 19, 2007 .............................................

A-17. Powells Creek near Turbeville, VA, January 23, 2008 .............................................51

\section{Tables}

1. Streamflow-gaging stations used for development of regional channel geometry curves for the Piedmont Physiographic Province in Virginia

2. Basin characteristics for study sites in the Piedmont Physiographic Province in Virginia

3. Bankfull channel geometry characteristics of study sites in the Piedmont Physiographic Province in Virginia.

4. Equations and diagnostic statistics relating drainage area to bankfull discharge and bankfull channel geometry for streams in the Piedmont Physiographic Province in Virginia 


\section{Conversion Factors and Datums}

\begin{tabular}{lcl}
\hline \multicolumn{1}{c}{ Multiply } & By & \multicolumn{1}{c}{ To obtain } \\
\hline inch (in.) & Length & \\
foot (ft) & 2.54 & centimeter $(\mathrm{cm})$ \\
mile (mi) & 0.3048 & meter $(\mathrm{m})$ \\
& 1.609 & kilometer $(\mathrm{km})$ \\
\hline square foot $\left(\mathrm{ft}^{2}\right)$ & Area & \\
square foot $\left(\mathrm{ft}^{2}\right)$ & 929.0 & square centimeter $\left(\mathrm{cm}^{2}\right)$ \\
square inch $\left(\mathrm{in}^{2}\right)$ & 0.0929 & square meter $\left(\mathrm{m}^{2}\right)$ \\
square mile $\left(\mathrm{mi}^{2}\right)$ & 6.452 & square centimeter $\left(\mathrm{cm}^{2}\right)$ \\
square mile $\left(\mathrm{mi}^{2}\right)$ & 259.0 & hectare $(\mathrm{ha})$ \\
\hline & 2.590 & square $\mathrm{kilometer}\left(\mathrm{km}^{2}\right)$ \\
\hline cubic foot $\left(\mathrm{ft}^{3}\right)$ & Volume & \\
cubic foot $\left(\mathrm{ft}^{3}\right)$ & 28.32 & liter $(\mathrm{L})$ \\
\hline & 0.02832 & cubic meter $\left(\mathrm{m}^{3}\right)$ \\
\hline foot per second $(\mathrm{ft} / \mathrm{s})$ & Flow rate & \\
cubic foot per second $\left(\mathrm{ft}^{3} / \mathrm{s}\right)$ & 0.3048 & meter per second $(\mathrm{m} / \mathrm{s})$ \\
cubic foot per second per & 0.02832 & cubic meter per second $\left(\mathrm{m}^{3} / \mathrm{s}\right)$ \\
square $\left.\mathrm{mile}^{2}\left(\mathrm{ft}{ }^{3} / \mathrm{s}\right) / \mathrm{mi}^{2}\right]$ & 0.01093 & cubic meter per second per square \\
\hline
\end{tabular}

Temperature in degrees Fahrenheit $\left({ }^{\circ} \mathrm{F}\right)$ may be converted to degrees Celsius $\left({ }^{\circ} \mathrm{C}\right)$ as follows:

$$
{ }^{\circ} \mathrm{C}=\left({ }^{\circ} \mathrm{F}-32\right) / 1.8
$$

Vertical coordinate information is referenced to the North American Vertical Datum of 1988 (NAVD 88).

Horizontal coordinate information is referenced to the North American Datum of 1983 (NAD 83) unless otherwise noted.

Altitude, as used in this report, refers to distance above the vertical datum. 


\title{
Regional Curves of Bankfull Channel Geometry for Non-Urban Streams in the Piedmont Physiographic Province, Virginia
}

\author{
By R. Russell Lotspeich
}

\begin{abstract}
Natural-channel design involves constructing a stream channel with the dimensions, slope, and plan-view pattern that would be expected to transport water and sediment and yet maintain habitat and aesthetics consistent with unimpaired stream segments, or reaches. Regression relations for bankfull stream characteristics based on drainage area, referred to as "regional curves," are used in natural stream channel design to verify field determinations of bankfull discharge and stream channel characteristics. One-variable, ordinary least-squares regressions relating bankfull discharge, bankfull cross-sectional area, bankfull width, bankfull mean depth, and bankfull slope to drainage area were developed on the basis of data collected at 17 streamflow-gaging stations in rural areas with less than 20 percent urban land cover within the basin area (non-urban areas) of the Piedmont Physiographic Province in Virginia. These regional curves can be used to estimate the bankfull discharge and bankfull channel geometry when the drainage area of a watershed is known.

Data collected included bankfull cross-sectional geometry, flood-plain geometry, and longitudinal profile data. In addition, particle-size distributions of streambed material were determined, and data on basin characteristics were compiled for each reach. Field data were analyzed to determine bankfull cross-sectional area, bankfull width, bankfull mean depth, bankfull discharge, bankfull channel slope, and D50 and D84 particle sizes at each site. The bankfull geometry from the 17 sites surveyed during this study represents the average of two riffle cross sections for each site. Regional curves developed for the 17 sites had coefficient of determination $\left(R^{2}\right)$ values of 0.950 for bankfull cross-sectional area, 0.913 for bankfull width, 0.915 for bankfull mean depth, 0.949 for bankfull discharge, and 0.497 for bankfull channel slope.
\end{abstract}

The regional curves represent conditions for streams with defined channels and bankfull features in the Piedmont Physiographic Province in Virginia with drainage areas ranging from 0.29 to 111 square miles. All sites included in the development of the regional curves were located on streams with current or historical U.S. Geological Survey streamflowgaging stations. These curves can be used to verify bankfull features identified in the field and bankfull stage for ungaged streams in non-urban areas.

\section{Introduction}

Rebuilding physically degraded stream channels has become a key element in the management of surface-water resources throughout the Nation. Driven largely by Section 404 of the Clean Water Act, many States are required to mitigate the effects to streams caused by construction, mining, and other activities. Loss of physical habitat and sedimentation in streams are among the most widespread causes of stream impairment. Restoration of a stream channel commonly is proposed and implemented by Federal, State, local, or private organizations in an effort to return the stream channels to more stable and biologically productive conditions.

Engineering practices for stream stabilization frequently rely on hardening the stream channel with riprap, gabions, concrete, or other countermeasures in reaches that are subjected to erosive forces. However, stream stabilization efforts that use natural-channel design techniques - with the philosophy of working with stream processes rather than resisting them-have become common practice in the Eastern United States and elsewhere. Natural-channel design, or "stream restoration," involves rebuilding a channel with the dimensions, slope, and plan-view pattern that will convey the water and sediment loads from the 
drainage basin without excessive aggradation or degradation. Stream channels designed to approximate natural, stable conditions are more likely to remain in equilibrium over time and, therefore, reduce erosion and sedimentation and provide suitable aquatic habitat (Rosgen, 1996). Many natural-channel designs are based on the geometry of the bankfull channel and the discharge occurring when the bankfull channel is flowing full.

Wolman and Miller (1960) defined bankfull discharge as the discharge that fills the channel to the beginning of the active flood plain, and showed that bankfull discharge typically has a recurrence interval of between 1 and 2 years. They also showed that the bankfull discharge is the discharge that moves the most sediment in a stream channel over time and, therefore, is responsible for the average geometric characteristics of the channel formed through erosional and depositional processes. The streamflow magnitude that moves the most sediment over time has been referred to as the effective discharge (Andrews, 1980).

The concepts that the bankfull discharge and effective discharge are equivalent, that they consistently recur every 1 to 2 years on a variety of rivers, and that they are responsible for the size and shape of channels have been disputed by some researchers and supported by others. Bankfull discharge may not, in all cases, be the effective discharge. Furthermore, the channel-forming discharge likely is representative of a range of flows that is responsible for the size and shape characteristics of the channel (Knighton, 1998). Knighton (1998) concludes that, although the standard assumptions may not hold for all conditions, for perennial rivers that do not have "very resistant boundaries" and occur in humid, temperate regions, the bankfull-as-effective-discharge model is the standard for channel design and river studies. The bankfull discharge, for the purposes of this report, is defined as the flow that represents, or is a surrogate for, the full range of flows forming the bankfull channel.

The bankfull discharge and bankfull channel geometry characteristics of cross-sectional area, width, and mean depth have been shown to be highly correlated with drainage area (Dunne and Leopold, 1978). In support of stream-restoration activities, regression relations between drainage area and bankfull characteristics are used to verify field identification of bankfull features in ungaged streams.

These regression relations typically are called regional curves because they are developed for a particular region characterized by similar climatic, physiographic, and geologic factors. These factors vary regionally and dictate the flow and sediment-transport processes that form channels (Leopold and Maddock, 1953; Leopold and others, 1964; Montgomery and Buffington, 1998). Regional curves recently have been developed to estimate bankfull geometry in the Coastal Plain Physiographic Provinces in Virginia and Maryland (Krstolic and Chaplin, 2007), the Valley and Ridge Physiographic Province in Virginia, Maryland, and West Virginia (Keaton and others, 2005), the Atlantic Coastal Plain Physiographic Province (Coastal Plain) in Maryland (McCandless, 2003), the Coastal Plain Physiographic Province in North Carolina
(Doll and others, 2003), and elsewhere in the Eastern United States (McCandless and Everett, 2002; Dudley, 2004; Chaplin, 2005; Sherwood and Huitger, 2005; Westergard and others, 2005). These bankfull regional curves are one-variable ordinary least-squares regressions relating bankfull channel geometry and discharge to drainage area for settings expected to have mostly homogenous hydrologic characteristics.

Prior to this study, no regional curves were available for the Piedmont Physiographic Province in Virginia, and the applicability of curves developed in other States was not known. As part of an ongoing effort to support stream restoration and natural-channel design in Virginia, the U.S. Geological Survey (USGS), in cooperation with the Virginia Transportation Research Council (VTRC), began development of bankfull regional curves for use in non-urban areas, where land use within a watershed is less than 20 percent urban, of the Piedmont Physiographic Province in Virginia in 2007.

\section{Purpose and Scope}

The purpose of this report is to present the data and results of bankfull regional curve development for non-urban streams in the Piedmont Physiographic Province in Virginia. Study sites were selected by following criteria used in recent similar studies. Bankfull geometry was surveyed in 2007-2008, and bankfull discharge was calculated at 17 streamflow-gaging stations and associated stream reaches. Regression relations between drainage area and bankfull characteristics for the study sites were developed, and basin characteristics were compiled. The regional curves developed for this study are compared to Piedmont regional curve datasets for surrounding States.

\section{Description of Study Area}

The Piedmont Physiographic Province in Virginia (the Piedmont) is bound to the west by the Blue Ridge Mountains and to the east by the Coastal Plain. The topology of the Piedmont mainly is composed of broad uplands with low to moderate slopes ranging in elevation from 600 to 1,000 feet ( $\mathrm{ft}$ ) in the west and gradually diminishing to $250-300 \mathrm{ft}$ in the east. The extreme western edge of the Piedmont is referred to as the Foothills and is characterized by broad rolling hills and moderate slopes with peaks rising to $1,500-2,500 \mathrm{ft}$. The Piedmont extends northward into Pennsylvania and southward into Alabama (fig. 1).

The geology of the Piedmont consists of Late Proterozoic and Paleozoic igneous and metamorphic rocks as well as lower Mesozoic sedimentary rocks, which are deposited in graben basins faulted into the igneous and metamorphic rocks. The Piedmont is divided geographically into two subprovinces, northern and southern, with the dividing line located roughly from Richmond to Lynchburg. This division is based on socioeconomic differences between the two subprovinces, with the northern province experiencing more rapid population growth and urban development than the southern province. Of the 
17 sites that were surveyed for this study, 9 are located in the northern Piedmont and 8 are in the southern Piedmont (fig. 1).

The climate of the Piedmont is moderate with typically cold winters and mild to hot summers. Average annual temperatures and rainfall range from 40 to 70 degrees Farenheit $\left({ }^{\circ} \mathrm{F}\right)$ and 40 to 45 inches, respectively (Southeast Regional Climate Center, 2007). Precipitation generally is distributed throughout the year, averaging 3 to 4 inches of rainfall per month.

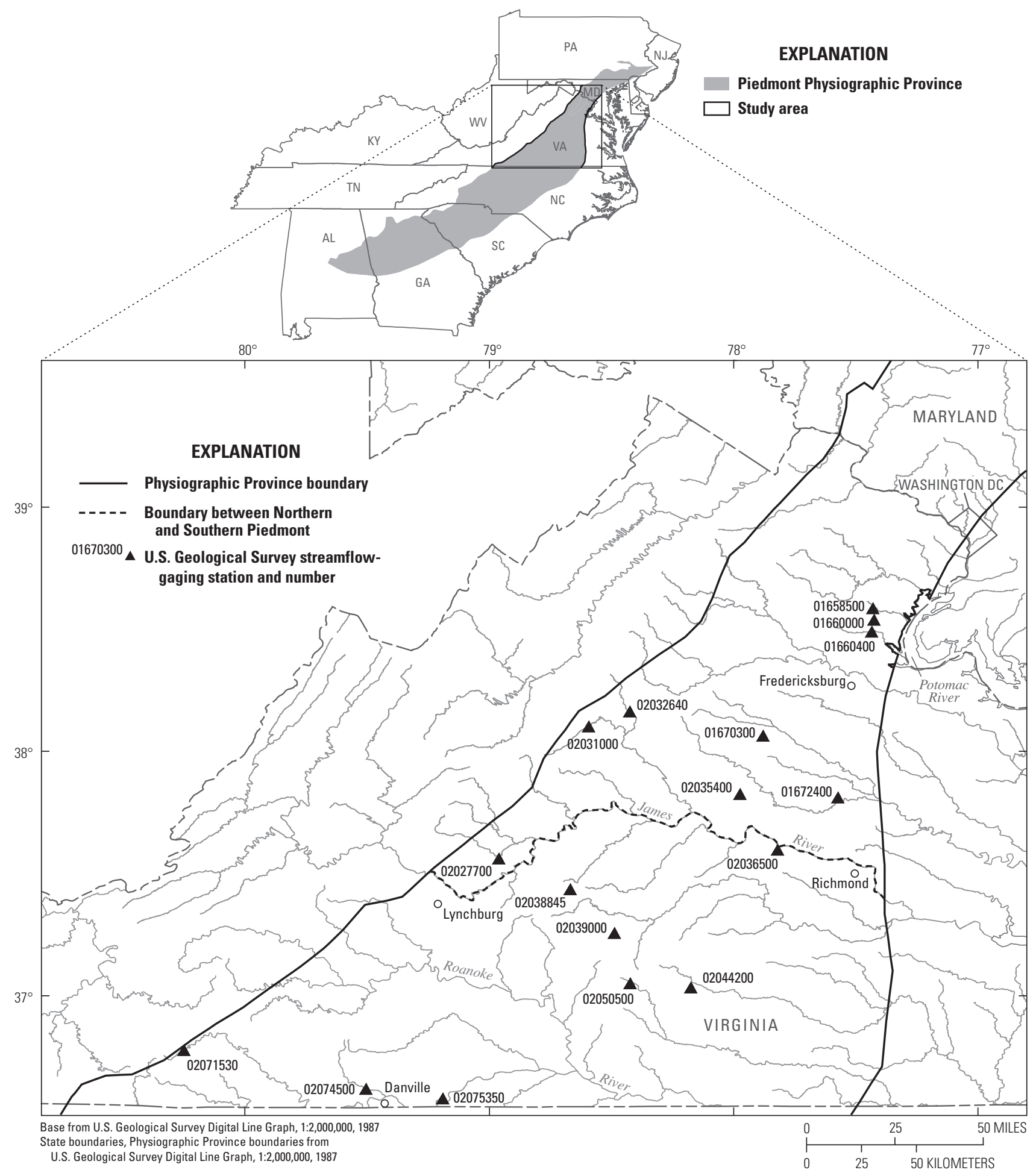

Figure 1. Location of streamflow-gaging stations used for development of regional channel geometry curves in the Piedmont Physiographic Province in Virginia. 


\section{Development of Piedmont Bankfull Regional Channel Geometry Curves}

The following sections discuss the data collection and analysis phases of this project. Included are the regression relations of bankfull channel geometry for non-urban streams in the Piedmont in Virginia.

\section{Site Selection}

Study sites were selected by following criteria used in recent similar studies (Cinotto, 2003; McCandless, 2003; Chaplin, 2005; Keaton and others, 2005; Krstolic and Chaplin, 2007). Streams with known major alterations, such as channelization, recent dredging, or manmade bank stabilization structures, were excluded from the study, although streamflow-gaging stations typically are located near roads and usually near a bridge or culvert. All streams with active or discontinued USGS streamflow-gaging stations in the Piedmont were evaluated against six selection criteria:

- At least 10 years of peak-flow data,

- Drainage basin area less than 250 square miles $\left(\mathrm{mi}^{2}\right)$,

- Drainage basin land use less than 20 percent urban,

- Flow regulated from less than 10 percent of the drainage area,

- Stream reach exhibiting consistent bankfull features over a length of approximately 20 bankfull channel widths, and

- Stream was wadeable at the time of the field survey.

Thirty-eight sites in the Piedmont met these criteria. Sites were selected on the basis of the criteria noted above, their location, and drainage basin size. A total of 26 sites were visited to determine if bankfull features were identifiable, and 17 were selected as study sites and surveyed for this study (table 1).

Table 1. Streamflow-gaging stations used for development of regional channel geometry curves for the Piedmont Physiographic Province in Virginia.

[dd mm ss, degree, minute, and second; $\mathrm{mi}^{2}$, square mile; $\mathrm{C}$, current]

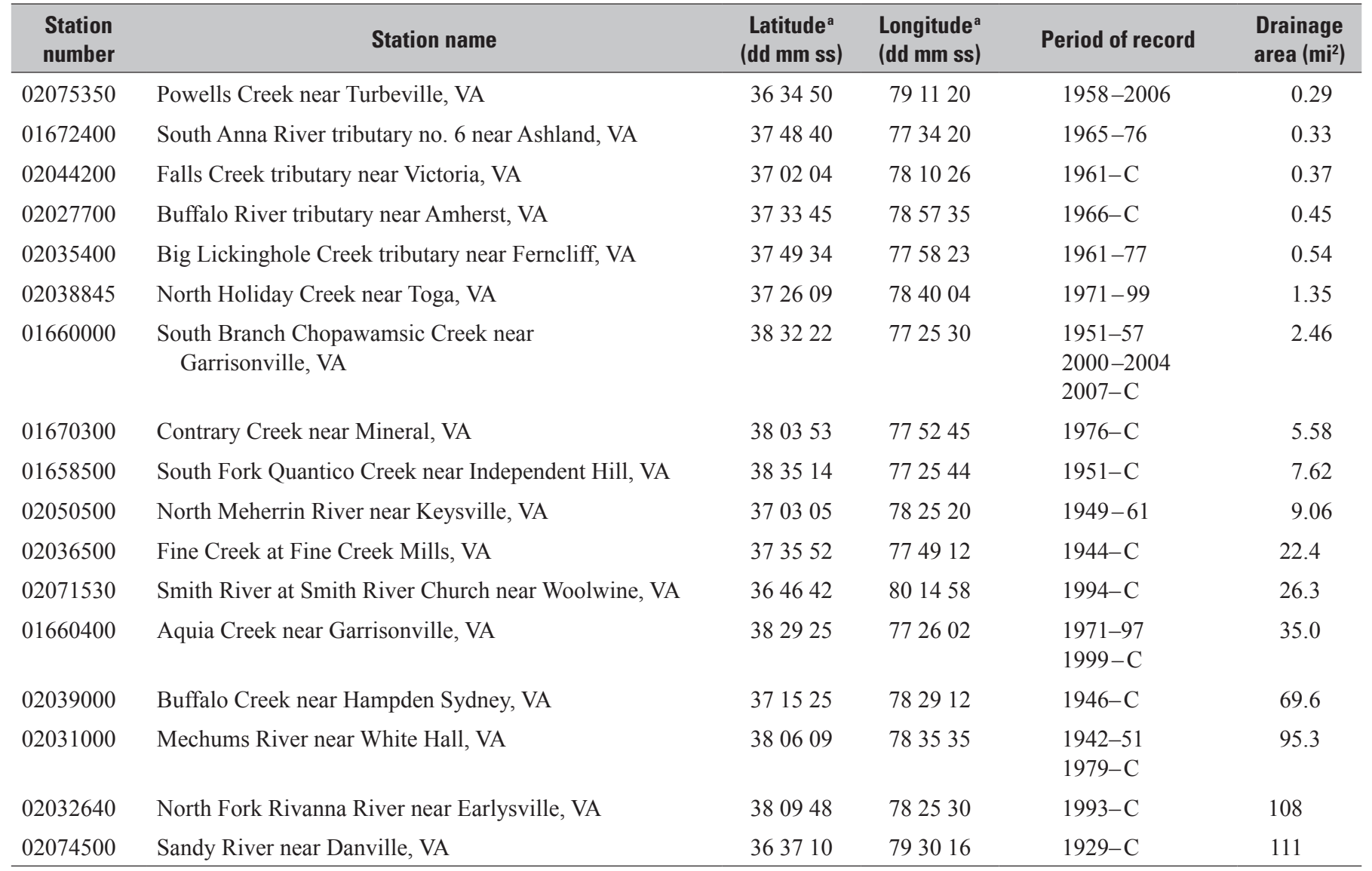

${ }^{a}$ North American Datum of 1927. 


\section{Identification of Bankfull Stage}

Before surveying each stream channel, the field team walked the length of the reach for a distance of at least 20 times the estimated bankfull width and identified morphologic features that were indicators of the bankfull stage, or the elevation at which the stream is flowing at bankfull. These identifiable bankfull features typically included at least one of the following:

- the top of the bank where the active flood plain begins

- the elevation of depositional features, such as a bench feature on the bank

- a prominent break in slope of the bank at an elevation lower than the top of the bank

A top of bank feature or a bench feature below the top of the bank typically defined the bankfull features for most study sites. A prominent break in slope was used at some study sites if the break in slope continued at a consistent level along a large portion of the study reach. If consistent bankfull features as listed above were not identifiable, the site was eliminated from the study.

\section{Surveys of Bankfull Channel}

All measurements of channel geometry (cross-sectional area, width, mean depth, and slope) for this study were made with regard to the bankfull stage. A two-person crew used a total station and theodolite (tools used in surveying to measure angles) to perform a vertical and horizontal survey of the morphologic features of each study site. The total station automatically calculated elevation, horizontal distance, and horizontal angle for each feature surveyed. A global positioning system was used to establish the coordinates and georeference the survey stream reach. All surveys except two were related to the reference datum for the site (the datum on which stagedischarge relations are based).

Two riffle cross sections were surveyed along with a longitudinal profile of each reach. Flood plains of cross sections usually were surveyed to the elevation of the floodprone stage, or twice bankfull maximum depth (Rosgen, 1996), or for some distance from the top of the bank for flat conditions. Longitudinal profiles were surveyed for a distance of up to 20 times the bankfull width. Measurements were taken of the thalweg, potential bankfull features, the top of the bank, and the water surface along the reach that extended past the streamflow-gaging station location.
The survey data were quality assured in the field by assessing the vertical and horizontal closure errors computed at the conclusion of each survey. If the vertical closure error was not within acceptable limits $(0.1 \mathrm{ft})$, the site was resurveyed until all errors were resolved. The survey data were also georeferenced to 1:24,000 USGS digital topographic maps to assess horizontal accuracy.

\section{Pebble Counts}

A modified version of the Wolman (1954) pebble count method was conducted to evaluate bed-material particlesize distributions for each riffle cross section. At each cross section, 100 bed-material particles were collected from the surface of the streambed. The particles were randomly selected at equal intervals across the channel from edge of bankfull feature to edge of bankfull feature. The intermediate axis of particles was measured with a ruler or sand gage designed for sizing very small particles. The length of the intermediate axis of each particle was categorized and recorded.

\section{Basin Characteristics}

Drainage area, land use, elevation, and precipitation regime were used to describe the characteristics of the study sites surveyed during this investigation (table 2). Digital representations of the basin boundaries in this study were delineated as part of an update of USGS drainage-basin areas for streamflow-gaging stations in Virginia (Hayes and Wiegand, 2006). The drainage area for each surveyed basin was obtained from this dataset. Drainage areas ranged from 0.29 to $111 \mathrm{mi}^{2}$, with seven sites having basins smaller than $5.0 \mathrm{mi}^{2}$.

A dataset representing the land use for the year 2001 (Goetz and others, 2004) was used to calculate the percentage of urban and forested land-use types for each basin. Urban land use ranged from 0.21 to 14.33 percent, and forested land use ranged from 12.73 to 90.55 percent, with only one site having less than 48 percent forested land use. Mean basin elevations were calculated using the USGS National Map Seamless Server "Elevation Profile Tool" (U.S. Geological Survey, 2008). Mean basin elevations for the surveyed sites ranged from 218 to 2,175 ft. Mean annual precipitation for the surveyed basins ranged between 42 and 46 inches with the maximum 24-hour rainfall during any 2 -year period ranging from 2.88 to 3.36 inches (Bonnin and others, 2004). 
Table 2. Basin characteristics for study sites in the Piedmont Physiographic Province in Virginia.

[mi² , square mile; ft, foot; NAVD 88, North American Vertical Datum of 1988; in., inch; n.d., no data]

\begin{tabular}{|c|c|c|c|c|c|c|c|}
\hline $\begin{array}{l}\text { Station } \\
\text { number }\end{array}$ & Station name & $\begin{array}{c}\text { Drainage } \\
\text { area } \\
\left(\mathrm{mi}^{2}\right)\end{array}$ & $\begin{array}{c}\text { Area } \\
\text { forested }^{a} \\
\text { (percent) }\end{array}$ & $\begin{array}{c}\text { Area } \\
\text { urbana }^{\mathrm{a}} \\
\text { (percent) }\end{array}$ & $\begin{array}{c}\text { Mean } \\
\text { basin } \\
\text { elevation }{ }^{\mathrm{b}} \\
\text { (ft NAVD 88) }\end{array}$ & $\begin{array}{c}\text { Mean } \\
\text { annual } \\
\text { precipitation } \\
\text { (in.) }\end{array}$ & $\begin{array}{l}\text { 24-hour, } \\
\text { 2-year } \\
\text { rainfallc } \\
\text { (in.) }\end{array}$ \\
\hline 02075350 & Powells Creek near Turbeville, VA & 0.29 & 12.73 & 8.97 & 462 & n.d. & 3.12 \\
\hline 01672400 & $\begin{array}{l}\text { South Anna River tributary no. } 6 \text { near } \\
\text { Ashland, VA }\end{array}$ & 0.33 & 58.57 & 0.21 & 218 & 43 & 3.12 \\
\hline 02027700 & Buffalo River tributary near Amherst, VA & 0.45 & 85.20 & 14.33 & 725 & 44 & 3.12 \\
\hline 02035400 & $\begin{array}{l}\text { Big Lickinghole Creek tributary near } \\
\text { Ferncliff, VA }\end{array}$ & 0.54 & 70.24 & 5.75 & 300 & 43 & 3.12 \\
\hline 02038845 & North Holiday Creek near Toga, VA & 1.35 & 77.97 & 3.95 & 710 & 43 & 3.12 \\
\hline 01660000 & $\begin{array}{l}\text { South Branch Chopawamsic Creek near } \\
\text { Garrisonville, VA }\end{array}$ & 2.46 & 79.83 & 7.65 & 295 & 42 & 2.88 \\
\hline 02050500 & North Meherrin River near Keysville, VA & 9.06 & 60.20 & 3.55 & 525 & 44 & 3.12 \\
\hline 02036500 & Fine Creek at Fine Creek Mills, VA & 22.4 & 65.79 & 0.51 & 262 & 43 & 3.12 \\
\hline 02071530 & $\begin{array}{l}\text { Smith River at Smith River Church near } \\
\text { Woolwine, VA }\end{array}$ & 26.3 & 78.78 & 0.36 & 2,175 & n.d. & 3.60 \\
\hline 01660400 & Aquia Creek near Garrisonville, VA & 35.0 & 72.04 & 7.62 & 265 & 42 & 2.88 \\
\hline 02039000 & Buffalo Creek near Hampden Sydney, VA & 69.6 & 66.50 & 0.34 & 475 & 44 & 3.12 \\
\hline 02031000 & Mechums River near White Hall, VA & 95.3 & 62.95 & 1.79 & 875 & 46 & 3.36 \\
\hline 02032640 & North Fork Rivanna River near Earlysville, VA & 108 & 67.94 & 1.16 & 1,300 & 46 & 3.36 \\
\hline
\end{tabular}

${ }^{a}$ Percent forested and urban areas from Goetz and others, 2004.

${ }^{\mathrm{b}}$ Mean basin elevation from The National Map Seamless Server (U.S. Geological Survey, 2008).

${ }^{\mathrm{c}}$ Maximum rainfall in 24 hours during any 2-year period (Bonnin and others, 2004).

\section{Analysis of Channel Data}

The 17 survey stream reaches were evaluated to determine the bankfull stage by using a combination of statistical analysis of annual peak discharges and streamflowgaging station stage-discharge relation and morphologic characteristics of the channel. A flood-frequency analysis was performed for each station by fitting a Log Pearson Type III frequency distribution to the logarithms of the annual peak discharges in the station record. This procedure generates recurrence intervals for a variety of discharges and is outlined in Bulletin 17B, Guidelines for Determining Flood-Flow Frequency (Hydrology Subcommittee of the Interagency Advisory Committee on Water Data, 1982). This information was used with the stage-discharge rating to determine the stages that corresponded to the 1- and 2-year discharge recurrence interval for the survey sites. The stage data along with historical stream channel geometry data, including width, mean depth, and cross-sectional area collected at discharge measurement cross sections, were used as a guide to help verify that field-identified bankfull features correspond to an elevation of approximately the 1- to 2-year recurrence interval.

Longitudinal profiles of the bankfull features, the water surface at the time of the survey, and the channel bed were plotted. The distances of all surveyed bankfull features above the water surface were calculated and compared throughout the reach. Only those surveyed features with a consistent elevation relative to the water surface at the time of the survey were included in the final analysis. A simple linear regression of the bankfull feature points for the entire reach was generated to develop a continuous representation of the bankfull profile. This technique allowed the bankfull profile to represent the average bankfull elevation throughout the reach and provided a means to calculate the bankfull stage at the gaging station and at each cross section by using all of the data collected. It is important to use all of the bankfull data because any individual feature is identified subjectively and is potentially erroneous (Leopold, 1994). 
The bankfull profile typically extended past the streamflow-gaging station, and the bankfull stage was estimated to be where the bankfull best-fit line crossed the station location. This estimated bankfull stage was used to determine the corresponding bankfull discharge. This discharge was compared to the results of the peakflow analysis, and its recurrence interval was calculated.

The bankfull stage for each riffle cross section was determined by entering the location of each cross section into the equation of the bankfull best-fit line along the longitudinal profile. The slope of the best-fit line was used as the slope of the bankfull channel. Each of the two riffle cross sections was then plotted, and the bankfull stage was identified on the plots (see Appendix). The bankfull cross-sectional area, width, and mean depth were calculated for each cross section, and the geometries of the two were averaged. These averages account for differences in channel geometry throughout the surveyed reach rather than using the calculated geometries from just one cross section.

The pebble count data were grouped into size categories according to the particle-size classification system published by Rosgen (1996). A cumulative frequency distribution of the particle sizes was constructed by plotting cumulative percentages against the size categories. From this information, the D50 and D84 (the particle sizes that are larger than 50 percent and 84 percent, respectively, of the material sampled) were determined. The D50 is the median particle size, and the D84 represents the particle size that is two standard deviations larger than the median (Leopold and others, 1964).

\section{Bankfull Discharge Determination}

Previous regional curve studies have calculated the bankfull discharge by relating the bankfull stage at the gage location to the stage-discharge rating. The discharge corresponding to the bankfull stage (rated discharge) was then used to develop the bankfull discharge regional curve. The rated discharge for the Piedmont study sites was determined, but a second approach, using the USGS slopearea computation program (SAC), also was employed. SAC follows USGS standardized procedures for computing discharge by the slope-area method (Dalrymple and Benson, 1967). The SAC program solves steady-state energy and continuity equations for discharge given upstream and downstream water-surface elevations (U.S. Geological Survey Water Resources Applications Software, 2009). The D50 particle size was used to determine the roughness coefficient (n-value) for each survey site cross section. Each study site reach was generally free of debris and had very little vegetation within the bankfull channel, which made the use of the D50 from each cross section a reasonable approximation of the roughness. The calculated bankfull crosssectional area was used at each survey site cross section.

Two of the study sites in this study had identifiable bankfull features, but no gage datum reference marks were located. The survey for these sites was conducted using an arbitrary starting elevation, yielding bankfull water-surface elevations that could not be referenced to the stage-discharge rating. Additionally, one site had a stage-discharge rating that yielded a rated bankfull discharge that did not compare well to the rest of the dataset. Because this site was a peak-flow site, more attention was paid to higher flows and very few discharge measuremens were made at low flows, yielding a rating that was poorly defined in the area of the bankfull stage. SAC was used to compute the bankfull discharges for these three sites so that they could be used to define the lower part of the bankfull discharge regional curve. The SAC (modeled) discharge for these sites were comparable to the rated discharges for the other sites in the dataset.

Modeled bankfull discharges were computed using SAC for all of the sites in the study. The rated discharges for all of the sites, except the one with the poorly defined rating, and the modeled discharges are shown in figure 2 . The site with the poorly defined rating was removed from the rated discharge dataset because, having the smallest drainage area in the dataset, this data point would have dictated a much different slope of the curve and skewed the comparison. In order to include the two sites that were not surveyed to gage datum, the SACgenerated discharges were used for all of the sites in the study to generate the Piedmont bankfull discharge regional curve.

Stream channel characteristics were compiled for the 17 survey stream reaches (table 3 ). These characteristics include the bankfull channel geometry used in the regional curves, the recurrence interval of the bankfull discharge, the 1.5-year discharge for the study sites, the cumulative D50 and D84 from the riffle pebble counts, and the average roughness coefficients used in SAC. Plots of longitudinal profiles, cross sections, and particle-size distributions are included in the appendix with site descriptions for each study site.

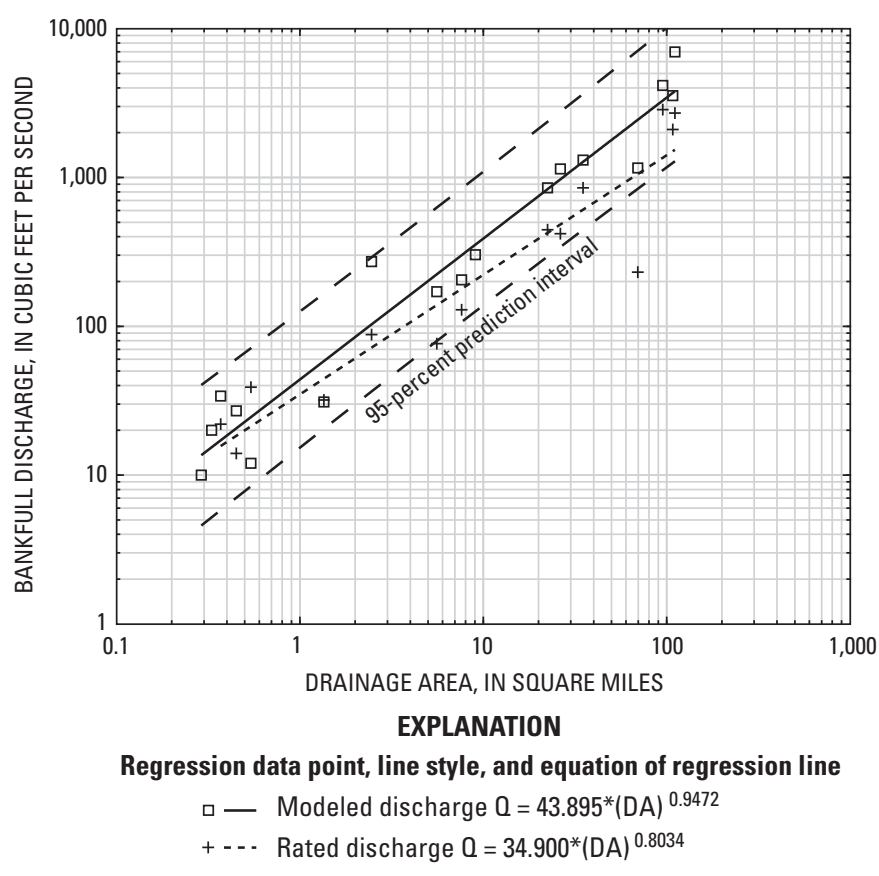

Figure 2. Log-log plot comparing regressions of modeled and rated bankfull discharge (0) to drainage area (DA) for non-urban streams in the Piedmont Physiographic Province in Virginia. 
Table 3. Bankfull channel geometry characteristics of study sites in the Piedmont Physiographic Province in Virginia.

$\left[\mathrm{mi}^{2}\right.$, square mile; $\mathrm{ft}^{2}$, square foot; $\mathrm{ft}$, foot; $\mathrm{ft}^{3} / \mathrm{s}$, cubic foot per second; $\mathrm{mm}$, millimeter; n.d., not determined]

\begin{tabular}{|c|c|c|c|c|c|c|c|c|c|c|c|}
\hline $\begin{array}{l}\text { Station } \\
\text { number }\end{array}$ & $\begin{array}{c}\text { Drainage } \\
\text { area } \\
\left(\mathrm{mi}^{2}\right)\end{array}$ & $\begin{array}{l}\text { Cross- } \\
\text { sectional } \\
\text { area }\left(\mathrm{ft}^{2}\right)\end{array}$ & $\begin{array}{c}\text { Width } \\
\text { (ft) }\end{array}$ & $\begin{array}{c}\text { Mean } \\
\text { depth } \\
\text { (ft) }\end{array}$ & $\begin{array}{c}\text { Discharge } \\
\left(\mathrm{ft}^{3} / \mathbf{s}\right)\end{array}$ & $\begin{array}{c}\text { Recurrence } \\
\text { interval } \\
\text { (years) }\end{array}$ & $\begin{array}{c}\text { 1.5-year } \\
\text { discharge } \\
\left(\mathrm{ft}^{3} / \mathrm{s}\right)\end{array}$ & $\begin{array}{l}\mathrm{D} 50^{\mathrm{a}} \\
(\mathrm{mm})\end{array}$ & $\begin{array}{l}\text { D84 } \\
(\mathrm{mm})\end{array}$ & $\begin{array}{l}\text { Channel } \\
\text { slope } \\
\text { (ft/ft) }\end{array}$ & $\begin{array}{l}\text { Roughness } \\
\text { coefficient }\end{array}$ \\
\hline 02075350 & 0.29 & 4.15 & 7.85 & 0.5 & 10 & n.d. & n.d. & 1.3 & 5 & 0.009 & 0.030 \\
\hline 01672400 & 0.33 & 5.75 & 9.05 & 0.6 & 20 & 1.4 & 23.8 & 13.5 & 46 & 0.015 & 0.032 \\
\hline 02044200 & 0.37 & 10.2 & 9.60 & 1.1 & 34 & 1.1 & 68.2 & 20.2 & 61 & 0.006 & 0.032 \\
\hline 02027700 & 0.45 & 6.94 & 11.3 & 0.6 & 27 & 1.5 & 26.0 & 14.3 & 54 & 0.015 & 0.030 \\
\hline 02035400 & 0.54 & 3.23 & 6.45 & 0.5 & 12 & n.d. & n.d. & 0.4 & 1 & 0.004 & 0.018 \\
\hline 02038845 & 1.35 & 9.08 & 9.38 & 1.0 & 31 & 1.3 & 48.5 & 18.8 & 48 & 0.007 & 0.032 \\
\hline 01660000 & 2.46 & 35.6 & 20.9 & 1.8 & 272 & 2.9 & 157 & 0.4 & 13 & 0.003 & 0.019 \\
\hline 01670300 & 5.58 & 54.7 & 50.3 & 1.1 & 171 & 1.0 & 330 & 21.6 & 52 & 0.004 & 0.031 \\
\hline 01658500 & 7.62 & 56.4 & 28.4 & 2.0 & 205 & 1.0 & 389 & 24.1 & 58 & 0.002 & 0.030 \\
\hline 02050500 & 9.06 & 60.6 & 29.2 & 2.1 & 303 & 1.0 & 699 & 22.4 & 35 & 0.004 & 0.031 \\
\hline 02036500 & 22.4 & 115 & 45.5 & 2.5 & 853 & 3.3 & 319 & 0.2 & 2 & 0.001 & 0.012 \\
\hline 02071530 & 26.3 & 172 & 68.6 & 2.5 & 1,140 & 2.1 & 744 & 50.3 & 125 & 0.006 & 0.033 \\
\hline 01660400 & 35.0 & 196 & 59.8 & 3.4 & 1,310 & 1.7 & 1,070 & 57.8 & 126 & 0.005 & 0.034 \\
\hline 02039000 & 69.6 & 147 & 45.3 & 3.3 & 1,160 & 1.6 & 1,060 & 0.1 & 1 & 0.002 & 0.018 \\
\hline 02031000 & 95.3 & 617 & 91.7 & 6.7 & 4,150 & 1.8 & 3,250 & 1.8 & 67 & 0.001 & 0.030 \\
\hline 02032640 & 108 & 597 & 96.4 & 6.1 & 3,550 & 1.2 & 4,700 & 11.3 & 46 & 0.002 & 0.030 \\
\hline 02074500 & 111 & 725 & 135 & 5.4 & 6,980 & 4.3 & 3,120 & 90.4 & 203 & 0.004 & 0.032 \\
\hline
\end{tabular}

${ }^{a}$ Median particle size of streambed material.

${ }^{\mathrm{b}}$ Particle size larger than 84 percent of streambed material.

${ }^{\mathrm{c}}$ Average of roughness coefficients used in slope-area computation input file for bankfull discharge determination.

\section{Piedmont Regional Curves}

Simple linear regression techniques were used to develop regional curves for the Piedmont in Virginia from channel geometry and discharge data collected at 17 study sites surveyed for this study (table 1). The response variablesbankfull cross-sectional area, bankfull width, bankfull mean depth, bankfull discharge, and bankfull slope - were regressed against the explanatory variable - drainage area. The relation between drainage area and each response variable was described by fitting a power function with a best-fit line through the data points for each parameter by using the least-squares method. The power functions were plotted on a log-log scale to maintain consistency with similar studies. The resulting power functions have the form: $y=a^{*}(\mathrm{DA}) b$. For the purpose of computing diagnostic statistics, the power functions were transformed to a log-linear form:

$$
\ln (y)=\ln (a)+(b * \ln (\mathrm{DA}))
$$

where:

$$
\begin{aligned}
\ln = & \text { natural log, base e, } \\
y & =\text { bankfull response variable, } \\
\mathrm{DA}= & \text { drainage area (explanatory variable) } \\
a & =\text { the intercept of the regression line, and } \\
b \quad= & \text { a coefficient of the regression line repre- } \\
& \text { senting the slope of the regression line. }
\end{aligned}
$$

The power functions that relate bankfull cross-sectional area, width, mean depth, discharge, and slope to drainage area are illustrated in figures 3-7. Table 4 gives the equations and diagnostic statistics for each regression. These regional

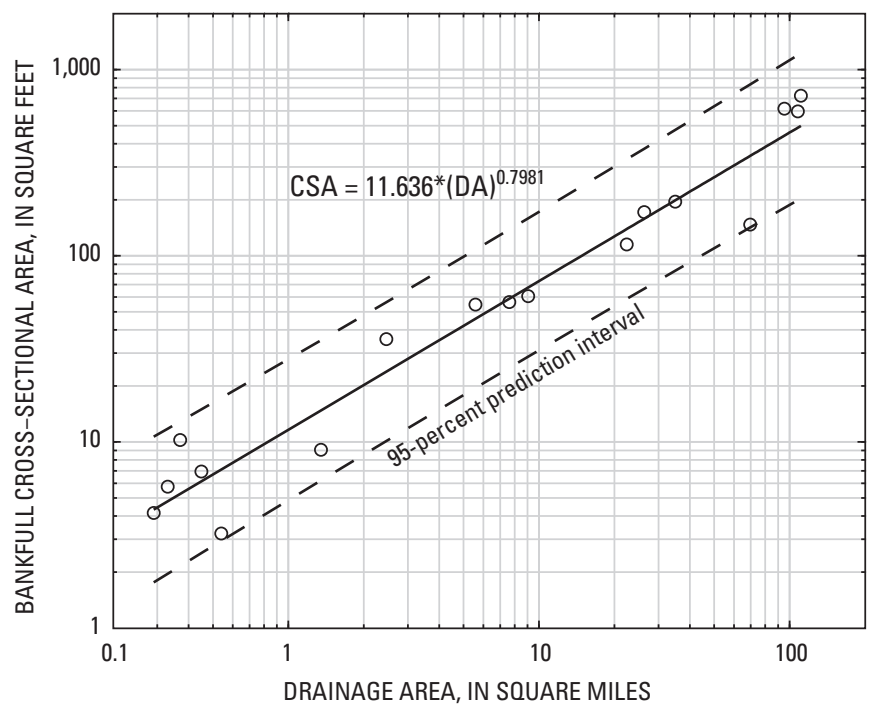

Figure 3. Regional curve relating bankfull cross-sectional area (CSA) to drainage area (DA) for non-urban streams in the Piedmont Physiographic Province in Virginia. 


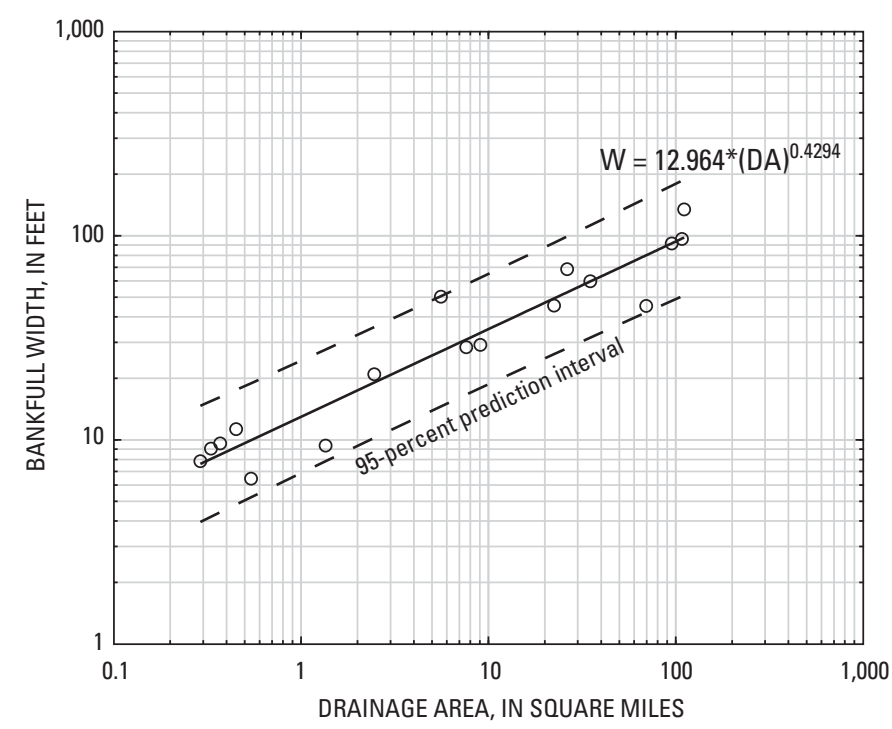

Figure 4. Regional curve relating bankfull width (W) to drainage area (DA) for non-urban streams in the Piedmont Physiographic Province in Virginia.

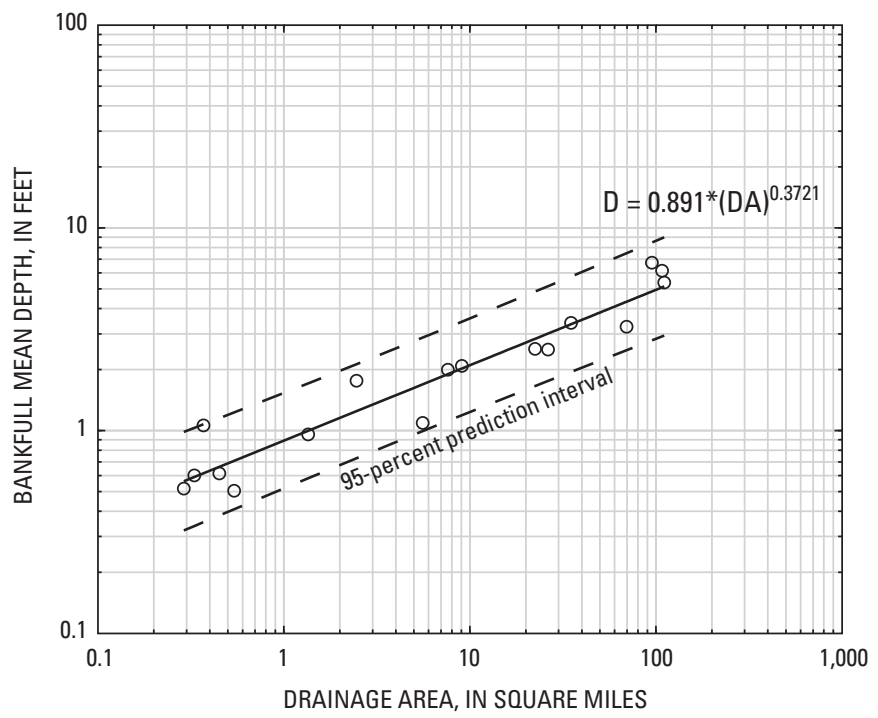

Figure 5. Regional curve relating bankfull mean depth (D) to drainage area (DA) for non-urban streams in the Piedmont Physiographic Province in Virginia.

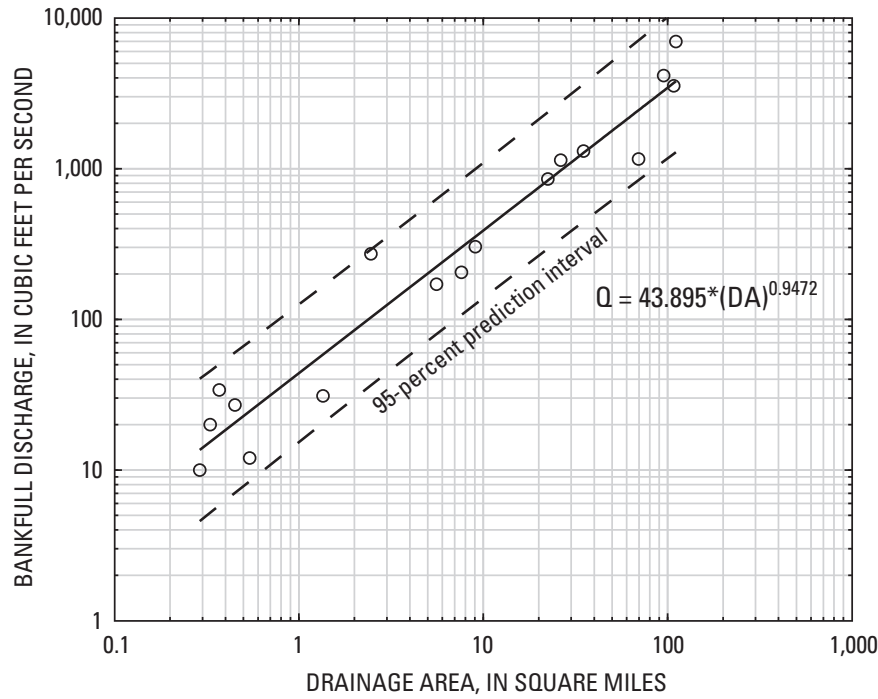

Figure 6. Regional curve relating bankfull discharge (Q) to drainage area (DA) for non-urban streams in the Piedmont Physiographic Province in Virginia.

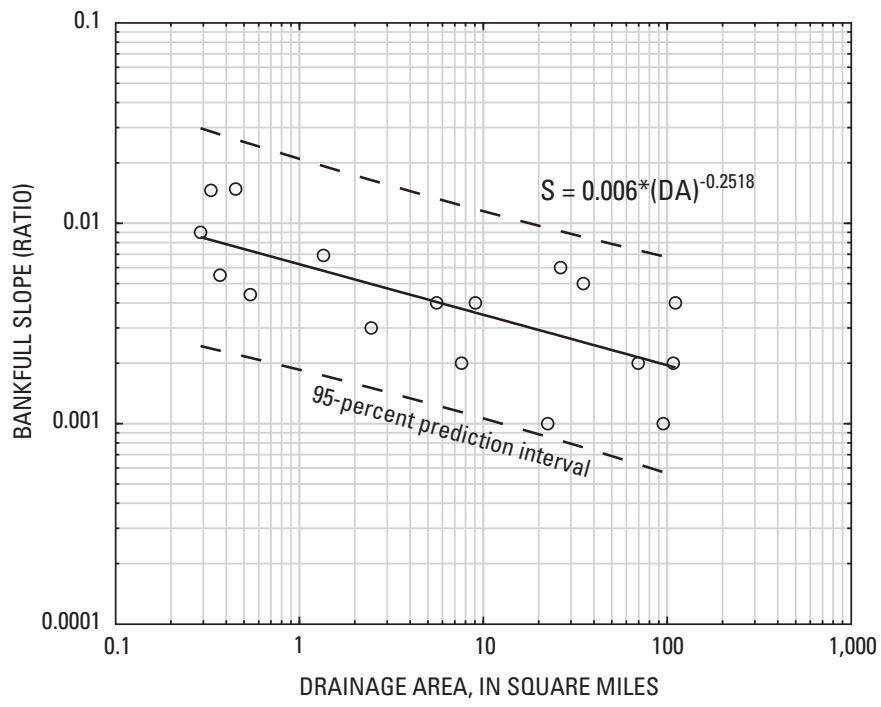

Figure 7. Regional curve relating bankfull slope (S) to drainage area (DA) for non-urban streams in the Piedmont Physiographic Province in Virginia. 
Table 4. Equations and diagnostic statistics relating drainage area to bankfull discharge and bankfull channel geometry for streams in the Piedmont Physiographic Province in Virginia.

$\left[\mathrm{R}^{2}\right.$, correlation coefficient; $n$, number of data points; CSA, bankfull cross-sectional area; DA, drainage area; W, bankfull width; $\mathrm{D}$, bankfull mean depth; Q, estimated bankfull discharge; S, bankfull channel slope; $<$, less than]

\begin{tabular}{lcccccc}
\hline \multicolumn{1}{c}{ Equation } & $\mathbf{R}^{2}$ & $\begin{array}{c}\text { Residual standard error } \\
\text { (natural log base e) }\end{array}$ & $n$ & $\begin{array}{c}\text { p-value for } \\
\text { regression slope }^{\text {a }}\end{array}$ & F-statistic & $\begin{array}{c}\text { PRESS } \\
\text { statistic }\end{array}$ \\
\hline $\mathrm{CSA}=11.636 *(\mathrm{DA}) 0.7981$ & 0.950 & 0.418 & 17 & $<0.0001$ & 287.43 & 3.475 \\
$\mathrm{~W}=12.964 *(\mathrm{DA}) 0.4294$ & 0.913 & 0.304 & 17 & $<0.0001$ & 157.30 & 1.737 \\
$\mathrm{D}=0.892 *(\mathrm{DA}) 0.3721$ & 0.915 & 0.260 & 17 & $<0.0001$ & 161.61 & 1.314 \\
$\mathrm{Q}=43.895 *(\mathrm{DA}) 0.9472$ & 0.949 & 0.504 & 17 & $<0.0001$ & 277.91 & 4.905 \\
$\mathrm{~S}=0.006 *(\mathrm{DA})-0.2520$ & 0.497 & 0.580 & 17 & 0.002 & 14.83 & 6.452 \\
\hline
\end{tabular}

${ }^{a} \mathrm{p}$-value less than 0.05 means that the slope of the regression is different than zero.

curves also show the 95-percent prediction intervals for individual estimates of the response variable. Prediction intervals represent a 95-percent certainty that an individual estimated value of $\mathrm{y}$ for a given $\mathrm{x}$ will fall within the upper and lower limits of the interval (Helsel and Hirsch, 2002, p. 242-245; Keaton and others 2005).

Regional curves (and other regression relations) are estimates of the true relation between bankfull response variables and drainage area because they are generated from a sample of sites intended to represent the population. The applicability of regional curves depends on how well the sample of sites represents the population, adherence to the assumptions of the underlying regression model, the fit of the regression relation, influence of any given data point, and confidence in the relation over the range of represented drainage areas. The applicability of regional curves developed here was evaluated on the basis of selected statistical diagnostics that measure the significance of the slope (indicated by p-values), the distribution of residuals, and the amount of variability explained by drainage area (given by $\mathrm{R}^{2}$ ). For this study, the slope of each regional curve was considered significantly different from zero if the p-value (probability that a difference occurs by chance) was less than 0.05 .

The regressions developed have slopes that are significantly different from zero with residuals that appear to be normally distributed and vary randomly with drainage area (figs. 8-12). Higher $\mathrm{R}^{2}$ values suggest that a greater portion of the variability is explained but is not necessarily indicative of a better regression relation. The $\mathrm{R}^{2}$ value of 0.950 indicates that 95.0 percent of the variability in bankfull cross-sectional area is explained by drainage area, with $91.3,91.5,94.9$, and 49.7 percent of the variability explained by drainage area for bankfull width, mean depth, discharge, and slope, respectively (table 4). The relatively high $\mathrm{R}^{2}$ values for cross-sectional area and discharge indicate a stronger relation to drainage area than the other parameters measured. Lower $\mathrm{R}^{2}$ values for bankfull width, mean depth, and slope indicate greater variability. Width and depth may vary considerably from site to site because of differences in local morphology; however, width and depth generally vary in opposite directions. Their productcross-sectional area - tends to be a more consistent characteristic and maintains a higher correlation with drainage area.
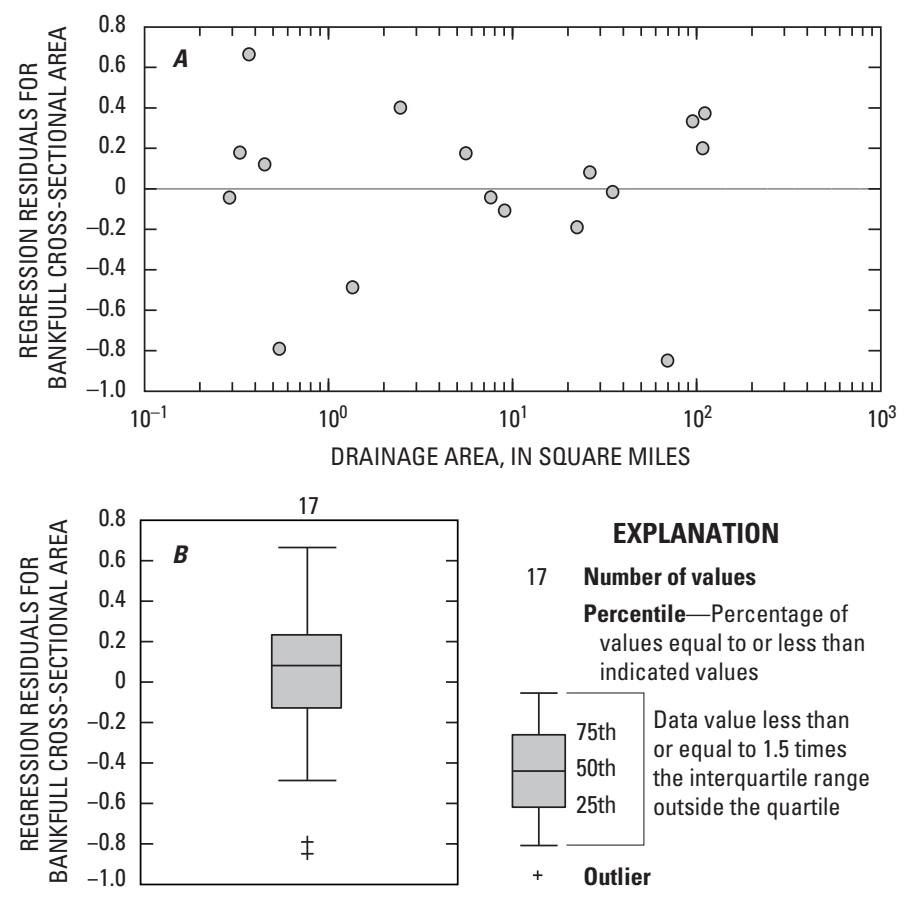

Figure 8. (A) Regression residuals for regional curves relating drainage area to bankfull cross-sectional area (for data see fig. 3) and (B) box plot of the distribution of residuals for bankfull cross-sectional area. 

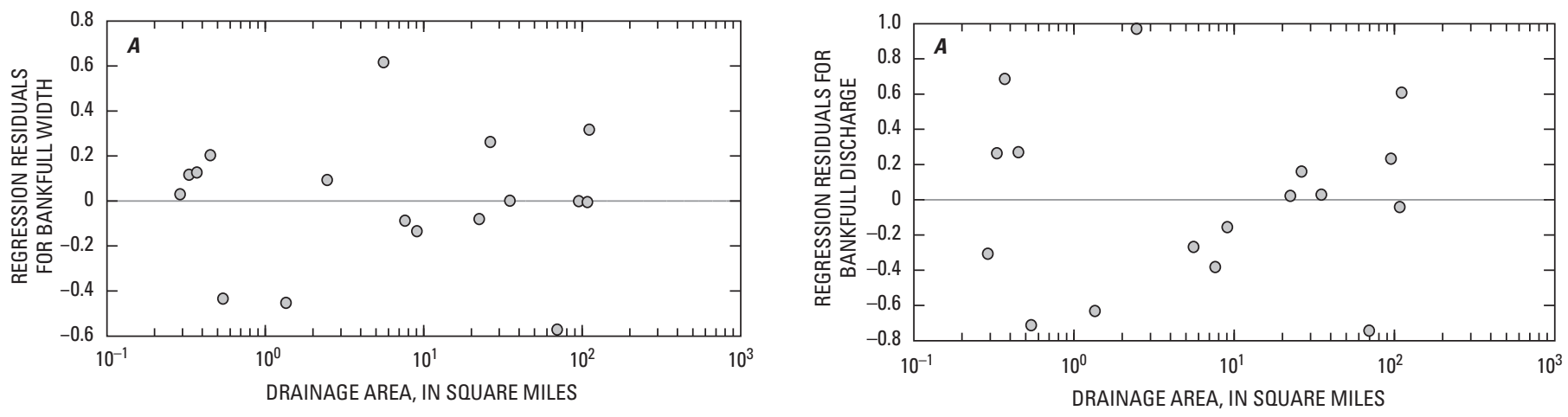

EXPLANATION

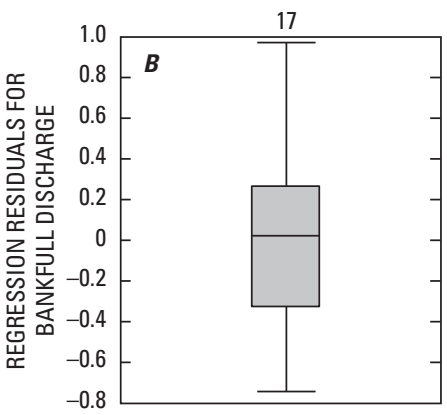

EXPLANATION

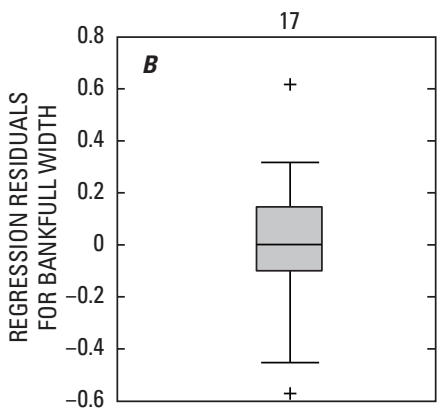

17 Number of values

$+\quad$ Outlier

Percentile-Percentage of values equal to or less than indicated values

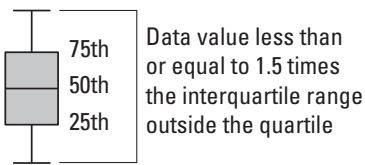

Figure 9. (A) Regression residuals for regional curves relating drainage area to bankfull width (for data see fig. 4) and (B) box plot of the distribution of residuals for bankfull width.
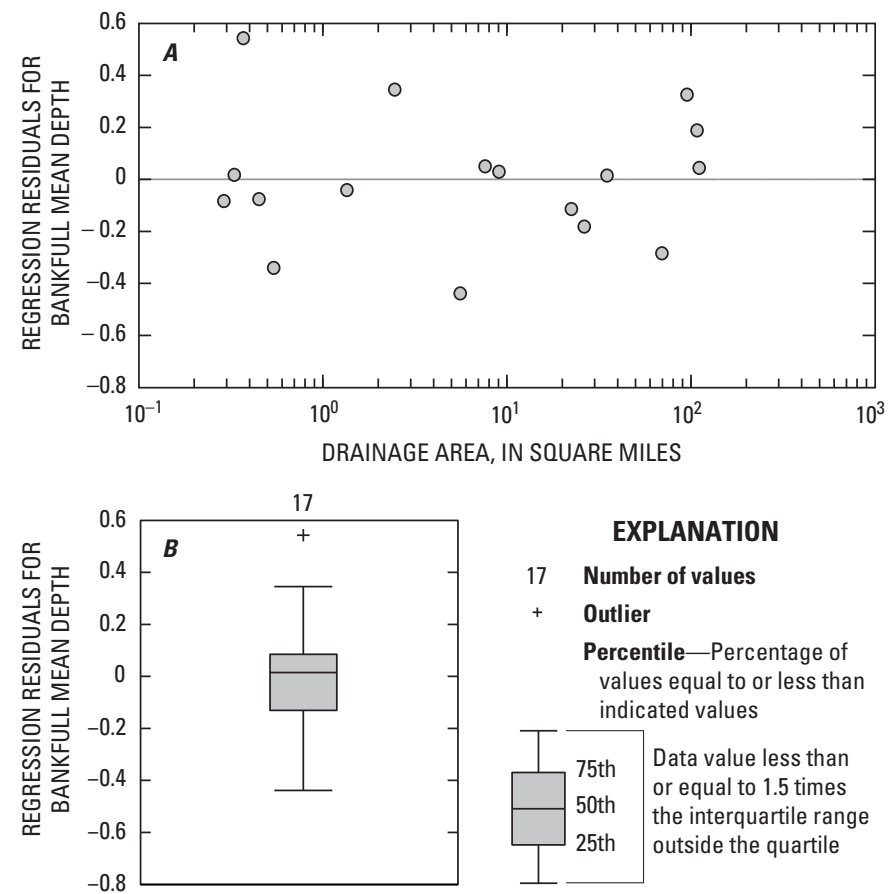

Figure 10. (A) Regression residuals for regional curves relating drainage area to bankfull mean depth (for data see fig. 5 ) and ( $B$ ) box plot of the distribution of residuals for bankfull mean depth.
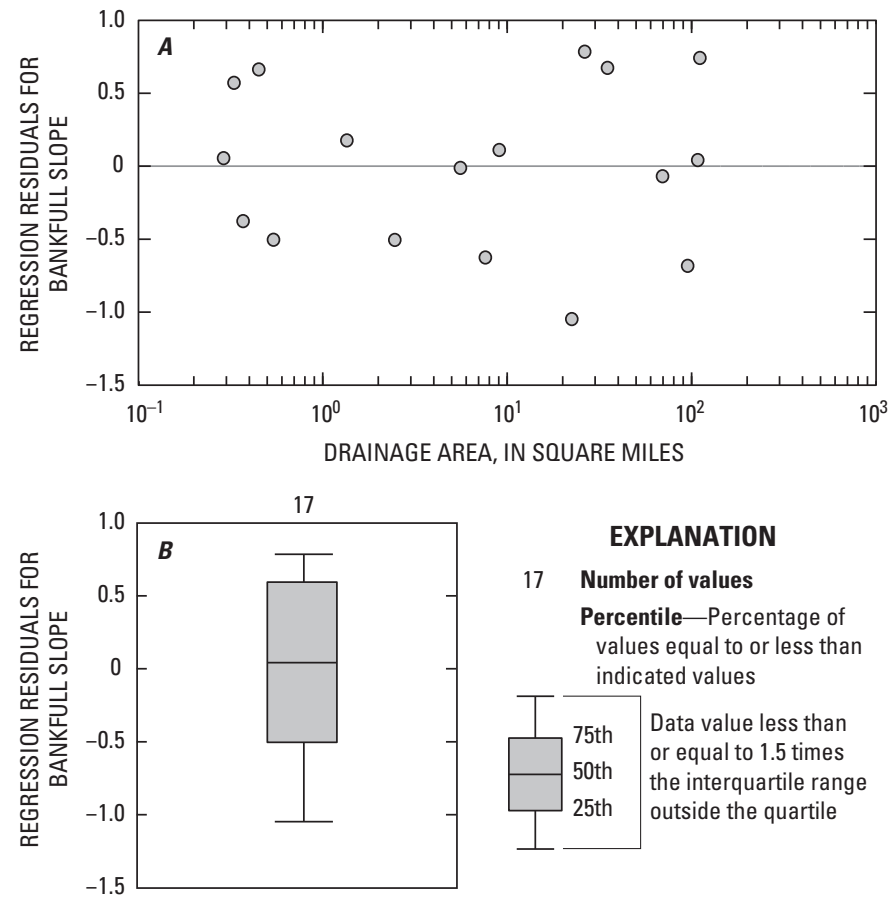

Figure 12. (A) Regression residuals for regional curves relating drainage area to bankfull slope (for data see fig. 7) and (B) box plot of the distribution of residuals for bankfull slope. 


\section{Limitations}

The bankfull regional curves presented in this report are applicable to the identification of bankfull geometry and discharge in non-urban streams of the Piedmont in Virginia. Factors, such as land use, stream gradient, stream type, mean elevation, and drainage area, should be considered when assessing the applicability of the Piedmont bankfull regional curves.

Streams included in this study had well-defined bankfull channel geometries that could be surveyed. Many streams were excluded from the dataset because of the site-selection requirements. The streams surveyed were in close proximity to a USGS streamflow-gaging station, which typically was mounted on a bridge or culvert. No assessment of habitat health was conducted, and no statements were made regarding habitat conditions. The regional curves provide an estimate of bankfull geometry and serve as tools for field identification of bankfull features that can be used in stream assessments of ungaged streams as a guide for identifying the expected natural-channel geometry in those streams. The regional curves are believed to be accurate within the prediction intervals for the range of drainage areas studied. Outside this range, it is uncertain how far, if at all, the regression relations may be extended with accuracy.

\section{Comparison of Mid-Atlantic Piedmont Regional Curves}

More than 15 sets of regional curves have been developed for physiographic provinces in the Eastern United States (Natural Resources Conservation Service, 2009). Dunne and Leopold (1978) found consistent patterns in channel geometry in this part of the country. The availability of data for the Piedmont in Virginia and the adjacent States of Pennsylvania, Maryland, and North Carolina provides an opportunity to examine regional patterns within one physiographic province. Individual regressions for Virginia $(\mathrm{n}=17)$, Pennsylvania ( $\mathrm{n}=11$; Chaplin, 2005), Maryland $(\mathrm{n}=3$; Chaplin, 2005), and North Carolina stations ( $n=13$; Harman and others, 1999) were plotted for comparison (figs. 13-17). Although the Maryland dataset is small $(n=3)$, it was included in this comparison to show all available data in the region. The plots indicate that the bankfull channel geometry curves developed for the Piedmont in Virginia are similar to those from neighboring States. Similar site-selection criteria, surveying techniques, and data-analysis procedures were used for all of these studies.

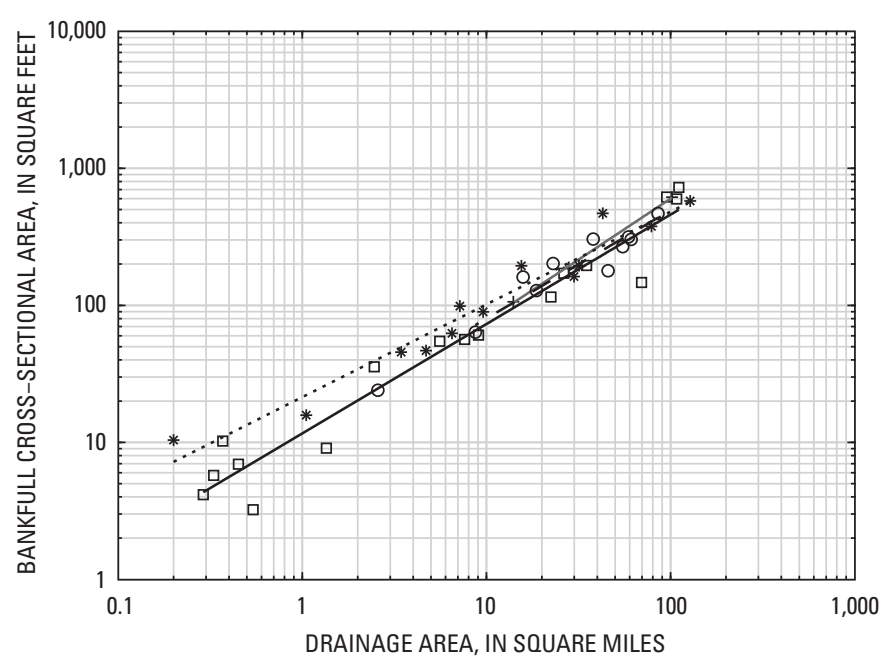

EXPLANATION

$$
\begin{array}{r}
\begin{array}{r}
\text { Regression data point, line style, equation of } \\
\text { regression line, and number of data points }
\end{array} \\
\circ-\quad \text { Pennsylvania CSA }=13.030(D A)^{0.7893} \quad(n=11) \\
+-\quad \text { Maryland CSA }=9.978(D A)^{0.8897} \quad(n=3) \\
\square-\quad \text { Virginia CSA }=11.636(D A)^{0.7981} \quad(n=17) \\
* \cdots \text { North Carolina CSA }=24.433(D A)^{0.6761 \quad(n=13)}
\end{array}
$$

Figure 13. Bankfull cross-sectional area (CSA) and drainage area (DA) for streams in the Piedmont Physiographic Province in Pennsylvania, Maryland, Virginia, and North Carolina.

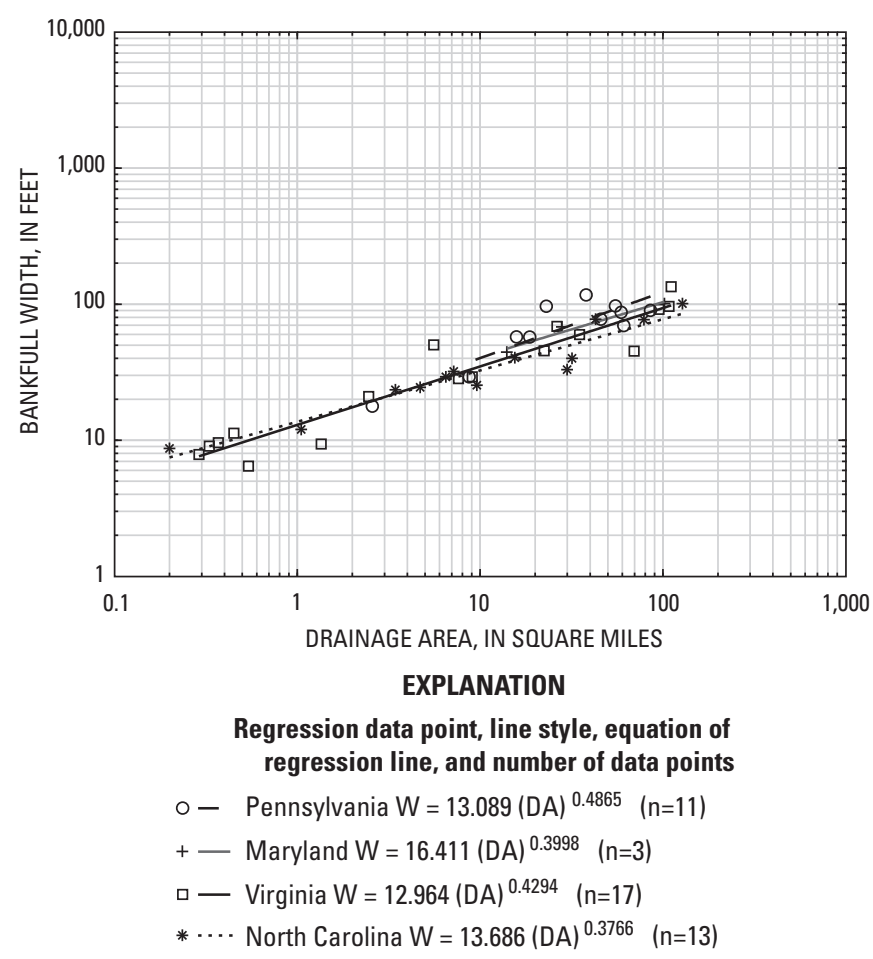

Figure 14. Bankfull width (W) and drainage area (DA) for streams in the Piedmont Physiographic Province in Pennsylvania, Maryland, Virginia, and North Carolina. 


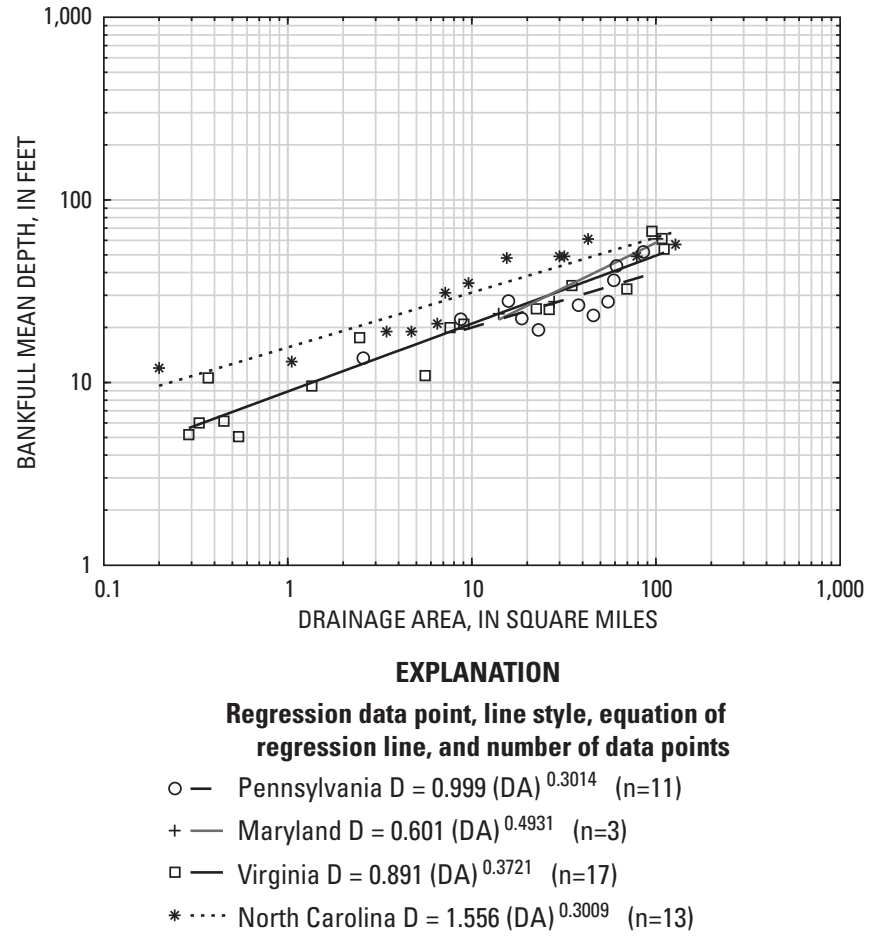

Figure 15. Bankfull mean depth (D) and drainage area (DA) for streams in the Piedmont Physiographic Province in Pennsylvania, Maryland, Virginia, and North Carolina.

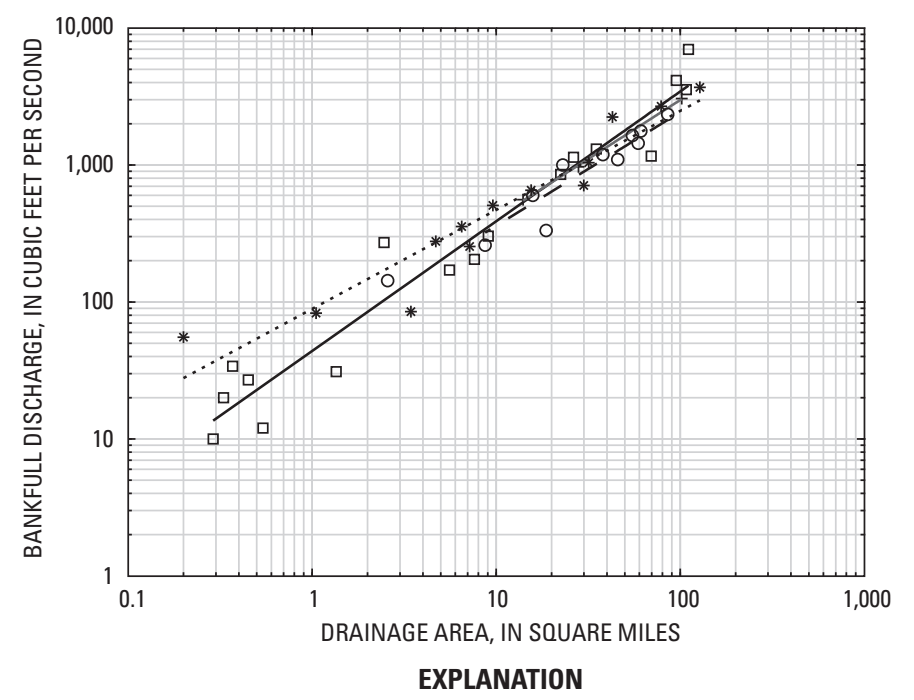

Regression data point, line style, equation of regression line, and number of data points

○- Pennsylvania $0=53.442$ (DA) ${ }^{0.8288} \quad(n=11)$

+ - Maryland $\mathrm{Q}=56.728(\mathrm{DA})^{0.8602}(\mathrm{n}=3)$

口- Virginia $0=43.895$ (DA) $0.9472 \quad(n=17)$

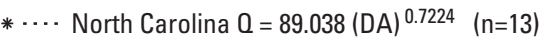

Figure 16. Bankfull discharge (0) and drainage area (DA) for streams in the Piedmont Physiographic Province in Pennsylvania, Maryland, Virginia, and North Carolina.

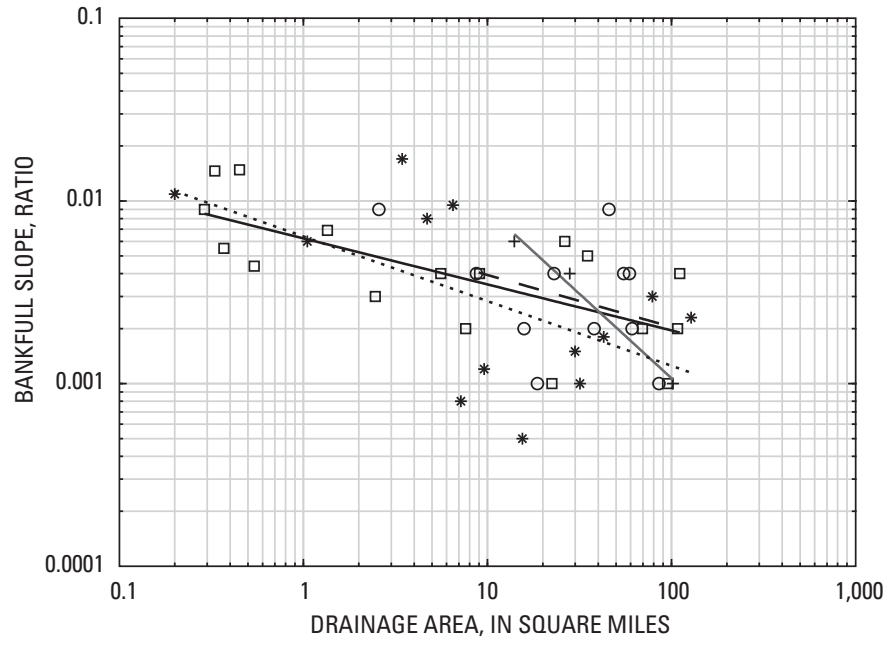

EXPLANATION

Regression data point, line style, equation of regression line, and number of data points

○- Pennsylvania $S=0.008$ (DA) ${ }^{-0.2843}(\mathrm{n}=11)$

+ - Maryland $S=0.075(D A)^{-0.9239} \quad(n=3)$

口- Virginia $S=0.006(D A)^{-0.2518} \quad(n=17)$

*... North Carolina $S=0.006(D A)^{-0.3542} \quad(n=13)$

Figure 17. Bankfull slope (S) and drainage area (DA) for streams in the Piedmont Physiographic Province in Pennsylvania, Maryland, Virginia, and North Carolina. 


\section{Summary}

The U.S. Geological Survey (USGS), in cooperation with the Virginia Transportation Research Council, undertook a 2-year study to develop regional curves that relate bankfull discharge and channel geometry to drainage area for streams in rural areas with less than 20 percent urban land cover within the basin area (non-urban areas) of the Piedmont Physiographic Province in Virginia. This study took place from 2007 to 2009 and included an assessment of 17 stream reaches at streamflow-gaging stations. Each assessment included a channel geometry survey, estimation of bankfull discharge, and analysis of streambed material. From the data collected, simple linear regression models, or regional curves, were developed for bankfull cross-sectional area, width, mean depth, discharge, and channel slope with respect to drainage area. These regional curves can be used to estimate the bankfull discharge and bankfull channel geometry when the drainage area of a watershed is known.

The bankfull geometry from the 17 study sites represents the average of two riffle cross sections for each site. Regional curves developed for the 17 sites had coefficient of determination $\left(\mathrm{R}^{2}\right)$ values of $0.950,0.913,0.915,0.949$, and 0.497 for bankfull cross-sectional area, width, mean depth, discharge, and channel slope, respectively. The regional curves represent conditions for non-urban streams with defined channels and bankfull features in the Piedmont Physiographic Province in Virginia with drainage areas ranging from 0.29 to 111 square miles. The regional curves were compared to similar regression models developed for data collected in Pennsylvania, Maryland, and North Carolina by the USGS. The regional curves developed for the current study were not significantly different from those developed for the other data sets.

All sites included in the development of the regional curves were located on streams with current or historical USGS streamflow-gaging stations. Although the regional curves developed in this study should not be expected to identify bankfull characteristics with precision, they are an important tool for stream assessment. The curves may be used in conjunction with detailed studies of fluvial systems and their drainage basins to estimate bankfull discharge and channel geometry characteristics.

\section{Acknowledgments}

The author would like to thank the following individuals for technical support on this project: Jennifer Krstolic, Nathan Beberdick, Brent Banks, Andrew Bernard, and Shaun Wicklein of the U.S. Geological Survey; John Matthews P.E., Robert Butler P.E., Alice Ortman P.E., and Ian Mohlie of the Virginia Department of Transportation Hydraulics group; and Mark Hartman of the Virginia Department of Transportation. In addition, Terence Messinger and Jeffrey Chaplin, of the U.S. Geological Survey, are acknowledged for providing technical reviews of this report.

\section{References Cited}

Andrews, E.D., 1980, Effective and bankfull discharges of streams in the Yampa River basin, Colorado and Wyoming: Journal of Hydrology, v. 46, p. 311-330.

Bonnin, G.M., Martin, D., Lin, B., Parzybok, T., Yekta, M., and Riley, D., 2004, Point precipitation frequency estimates, precipitation-frequency atlas of the United States: NOAA atlas 14, v. 2, version 3 NOAA, National Weather Service, Silver Spring, Maryland; accessed November 20, 2008, at http://hdsc.nws.noaa.gov/hdsc/pfds/orb/va_pfds.html.

Chaplin, J.J., 2005, Development of regional curves relating bankfull-channel geometry and discharge to drainage area for streams in Pennsylvania and selected areas of Maryland: U.S. Geological Survey Scientific Investigations Report 2005-5147, 34 p.

Cinotto, P.J., 2003, Development of regional curves of bankfull-channel geometry and discharge for streams in the non-urban Piedmont Physiographic Province, Pennsylvania and Maryland: U.S. Geological Survey Water-Resources Investigations Report 2003-4014, 27 p.

Dalrymple, T., and Benson, M.A., 1967, Measurement of peak discharges by the slope-area method: U.S. Geological Survey Techniques of Water-Resources Investigations, book 3, chap. A2, 12 p.

Doll, B.A., Dobbins, A.D., Spooner, Jean, Clinton, D.R., and Bidelspach, D.A., 2003, Hydraulic geometry relationships for rural North Carolina Coastal Plain streams: NC Stream Restoration Institute, Report to North Carolina Division of Water Quality for 319 Grant Project No. EW20011, 11 p.; accessed December 16, 2008, at http://www.ncsu.edu/sri.

Dudley, R.W., 2004, Hydraulic geometry relations for rivers in coastal and central Maine: U.S. Geological Survey Scientific Investigations Report 2004-5042, 19 p. + app.

Dunne, T., and Leopold, L.B., 1978, Water in environmental planning: San Francisco, CA, W.H. Freeman, 818 p.

Goetz, S.J., Jantz, C.A., Prince, S.D., Smith, A.J., Varlyguin, D., and Wright, R., 2004, Integrated analysis of ecosystem interactions with land use change-The Chesapeake Bay watershed, in DeFries, R.S., Asner, G.P., and Houghton, R.A., eds., Ecosystems and Land Use Change: Washington DC, American Geophysical Union, Geophysical Monograph Series, p. 263-275.

Harman, W.H., Jennings, G.D., Patterson, J.M., Clinton, D.R., Slate, L.O., Jessup, A.G., Everhart, J.R., and Smith, R.E., 1999, Bankfull hydraulic geometry relationships for North Carolina streams, in Olsen, D.S., and Potyondy, J.P., eds., AWRA Wildland Hydrology Symposium Proceedings: AWRA Summer Symposium, June 30-July 2, 1999, Bozeman, MT, 536 p. 
Hayes, D.C., and Wiegand, Ute, 2006, Drainage areas of selected streams in Virginia: U.S. Geological Survey Open-File Report 2006-1308, 51 p.

Helsel, D.R., and Hirsch, R.M., 2002, Statistical methods in water resources: U.S. Geological Survey Techniques of Water-Resources Investigations, book 4, chap. A3, 523 p.

Hydrology Subcommittee of the Interagency Advisory Committee on Water Data, 1982, Bulletin 17B, Guidelines for determining flood-flow frequency: U.S. Geological Survey, Office of Water Data Coordination [variously paged].

Keaton, J.N., Messinger, T., and Doheny, E.J., 2005, Devel opment and analysis of regional curves for streams in the non-urban Valley and Ridge Physiographic Province, Maryland, Virginia, and West Virginia: U.S. Geological Survey Scientific Investigations Report 2005-5076, 109 p.

Knighton, David, 1998, Fluvial forms and processes-A new perspective: London, Edward Arnold, 383 p.

Krstolic, J.L., and Chaplin, J.J., 2007, Bankfull regional curves for streams in the non-urban, non-tidal Coastal Plain Physiographic Province, Virginia and Maryland: U.S. Geological Survey Scientific Investigations Report 2007-5162, 48 p. (Also available at http://pubs. water.usgs.gov/sir2007-5162.)

Leopold, L.B., 1994, A view of the river: Cambridge, MA, Harvard University Press, 298 p.

Leopold, L.B. and Maddock, Thomas, Jr., 1953, The hydraulic geometry of stream channels and some physiographic implications: U.S. Geological Survey Professional Paper 252, $57 \mathrm{p}$.

Leopold, L.B., Wolman M.G., and Miller, J.P., 1964, Fluvial processes in geomorphology: New York, Dover Publications, Inc., $552 \mathrm{p}$.

McCandless, T.L., 2003, Maryland stream survey-Bankfull discharge and channel characteristics in the coastal plain hydrologic region: U.S. Fish and Wildlife Service, Chesapeake Bay Field Office Report S03-02, 28 p. + app.

McCandless, T.L., and Everett, R.A., 2002, Maryland stream survey_Bankfull discharge and channel characteristics of streams in the Piedmont hydrologic region: U.S. Fish and Wildlife Service, Chesapeake Bay Field Office Report S02-01, 40 p. + app. A and B.
Montgomery, D.R., and Buffington, J.M., 1998, Channel processes, classification, and response, in Naiman, R.J., and Bilby, R.E., River ecology and management_-Lessons from the Pacific Coastal ecoregion: New York, Springer-Verlag, p. $13-42$.

Natural Resources Conservation Service, 2009, Regional hydraulic geometry curves: Natural Resources conservation Service, National Water Management Center; accessed January 6, 2009, at http://wmc.ar.nrcs.usda.gov/technical/ HHSWR/Geomorphic/index.html.

Rosgen, D.L., 1996, Applied river morphology (2d ed.): Pagosa Springs, CO, Wildland Hydrology [variously paged].

Sherwood, J.M., and Huitger, C.A., 2005, Bankfull characteristics of Ohio streams and their relation to peak streamflows: U.S. Geological Survey Scientific Investigations Report 2005-5153, 38 p.

Southeast Regional Climate Center, 2007, Historical climate summaries for Virginia: Chapel Hill, NC, Southeast Regional Climate Center, The University of North Carolina; accessed November 18, 2008, at http://www.sercc.com/ climateinfo/historical/historical_va.html.

U.S. Geological Survey, 2008, The National Map Seamless Server: U.S. Geological Survey, accessed November 19, 2008, at http://seamless.usgs.gov/.

U.S. Geological Survey, 2009, Water Resources Applications Software, Summary of SAC: U.S. Geological Survey, accessed January 6, 2009, at http://water.usgs.gov/ cgi-bin/man_wrdapp?sac.

Westergard, B.E., Mulvihill, C.I., Ernst, A.G., and Baldigo, B.P., 2005, Regionalized equations for bankfulldischarge and channel characteristics of streams in New York State-Hydrologic region 5 in central New York: U.S. Geological Survey Scientific Investigations Report 2004-5247, 16 p.

Wolman, M.G., 1954, A method of sampling coarse river-bed material: Transactions of the American Geophysical Union, v. 35, p. 951-956.

Wolman, M.G., and Miller, J.C., 1960, Magnitude and frequency of forces in geomorphic processes: Journal of Geology, v. 68 p. 54-74. 



\section{Appendix}

Station 01658500 South Fork Quantico Creek near Independent Hill, VA........................................18

Station 01660000 South Branch Chopawamsic Creek near Garrisonville, VA.................................20

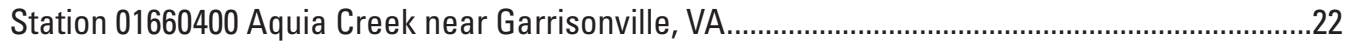

Station 01670300 Contrary Creek near Mineral, VA ……….............................................................24

Station 01672400 South Anna River tributary near Ashland, VA ...................................................26

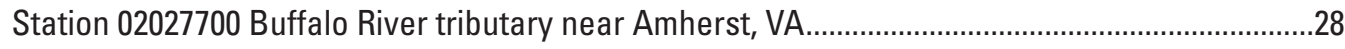

Station 02031000 Mechums River near White Hall, VA ..............................................................30

Station 02032640 North Fork Rivanna River near Earlysville, VA ...................................................32

Station 02035400 Big Lickinghole Creek tributary near Ferncliff, VA ............................................34

Station 02036500 Fine Creek at Fine Creek Mills, VA …...........................................................36

Station 02038845 North Holiday Creek near Toga, VA...............................................................38

Station 02039000 Buffalo Creek near Hampden Sydney, VA........................................................40

Station 02044200 Falls Creek tributary near Victoria, VA ..............................................................42

Station 02050500 North Meherrin River near Keysville, VA ..........................................................4

Station 02071530 Smith River at Smith River Church near Woolwine, VA.......................................46

Station 02074500 Sandy River near Danville, VA .........................................................................

Station 02075350 Powells Creek near Turbeville, VA …….............................................................50 


\section{Station 01658500}

\section{South Fork Quantico Creek near Independent Hill, VA}

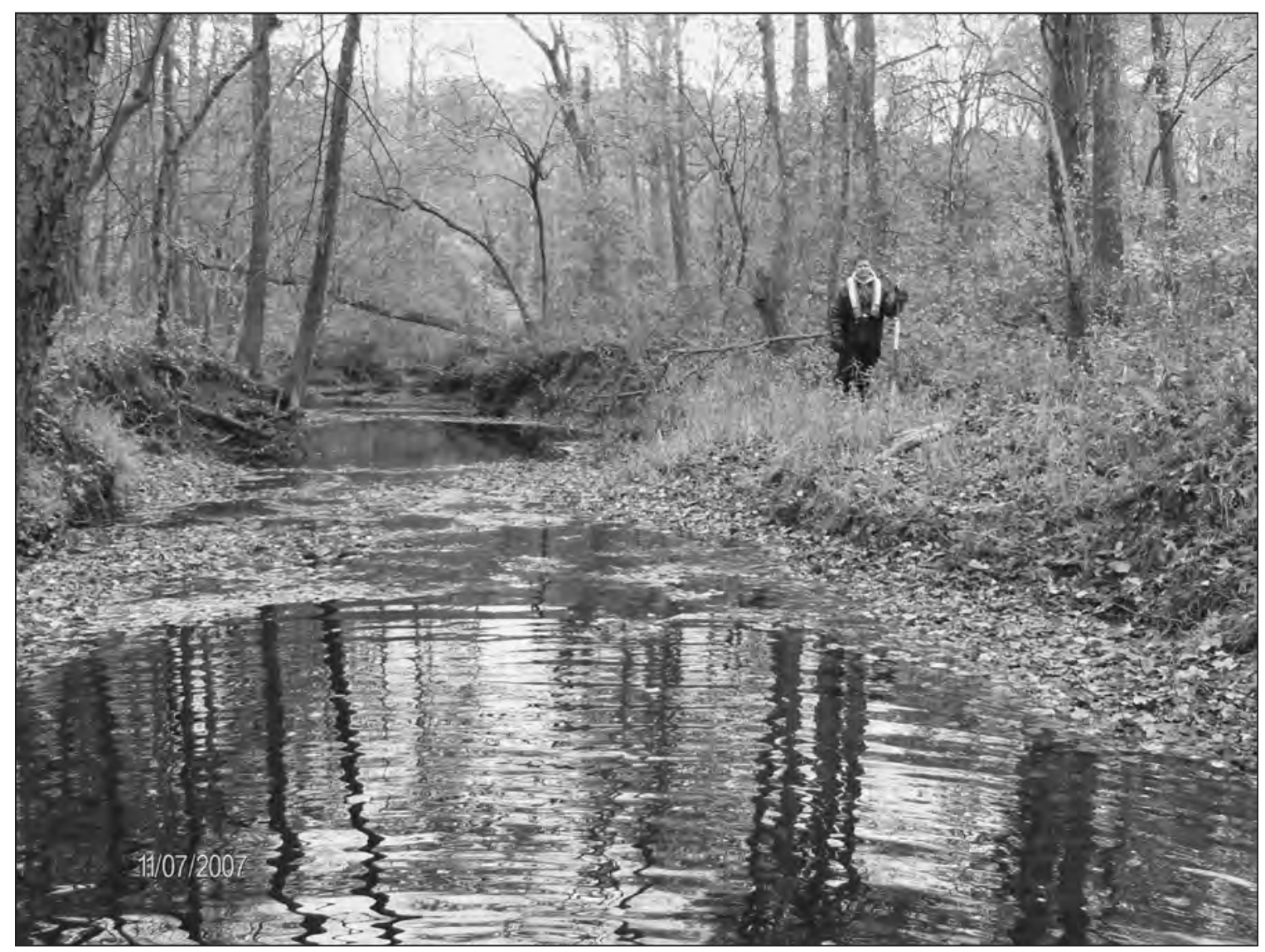

View looking downstream at reach for South Fork Quantico Creek near Independent Hill, VA.

LOCATION—Lat $38^{\circ} 35^{\prime} 14^{\prime \prime}$, long $77^{\circ} 25^{\prime} 44^{\prime \prime}$ referenced to North American Datum of 1927, Prince William County, VA, Hydrologic Unit 02070011, on right bank at upstream side of bridge on State Highway 619, 3.4 mi south of Independent Hill, 5.6 mi west of Dumfries, and 6.5 mi upstream from mouth.

DRAINAGE AREA-7.62 $\mathrm{mi}^{2}$.

REMARKS - The stream flows into Prince William Forest Park from Quantico Marine Corps Base. The watershed is 90.6 percent forested. The channel maintains a consistent geometry throughout the surveyed reach, consisting of moderately steep banks extending up to a nearly flat floodplain on both banks. The main bankfull features in the channel are depositional features. The bed is mostly sand and gravel with some small cobbles. 

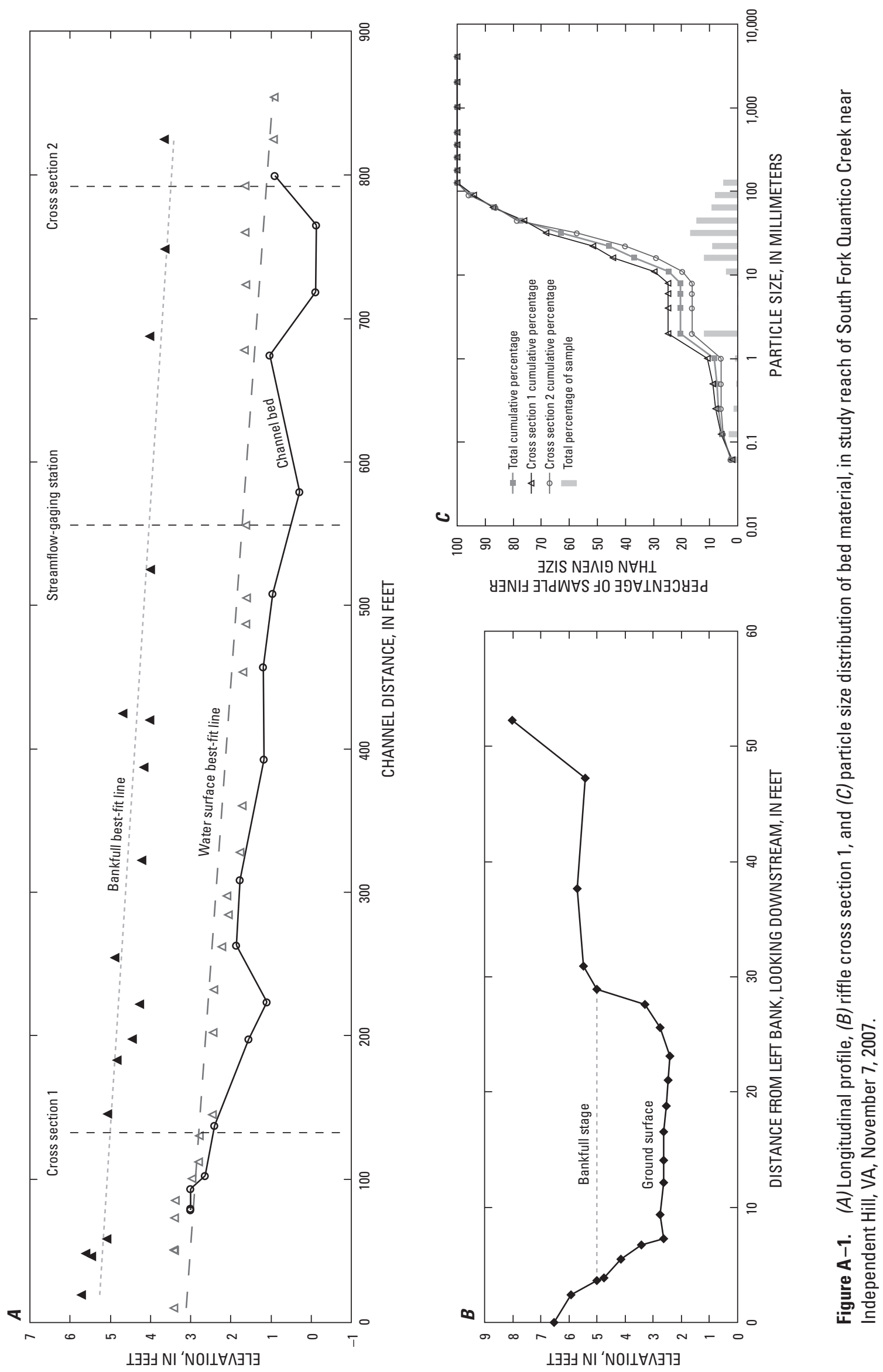


\section{Station 01660000}

\section{South Branch Chopawamsic Creek near Garrisonville, VA}

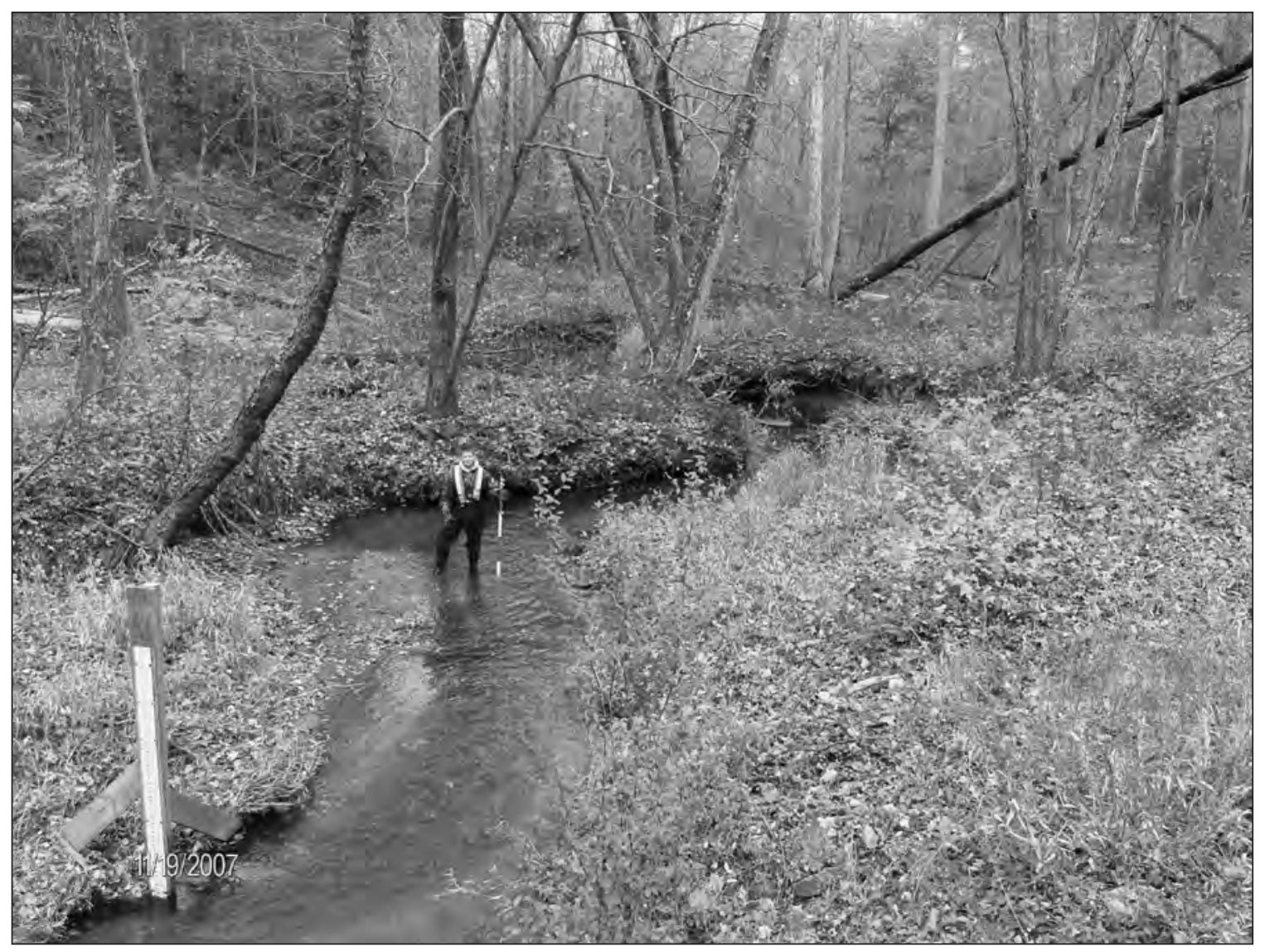

View looking downstream at reach for South Branch Chopawamsic Creek near Garrisonville, VA.

LOCATION - Lat $38^{\circ} 32^{\prime} 22^{\prime \prime}$, long $77^{\circ} 25^{\prime} 30^{\prime \prime}$ referenced to North American Datum of 1927, Stafford County, VA, Hydrologic Unit 02070011, on left bank, $10 \mathrm{ft}$ downstream of Highway MCB-1, 1.8 mi upstream from Chopawamsic Creek, and 4.3 mi north of Garrisonville.

DRAINAGE AREA-2.46 mi².

REMARKS - The watershed drains Quantico Marine Corps Base. The watershed is 79.8 percent forested. The channel maintains a consistent geometry throughout the surveyed reach, consisting of moderately steep banks extending up to a nearly flat floodplain on both banks. The main bankfull features in the channel are depositional features. The bed is mostly sand and gravel with some small cobbles. 

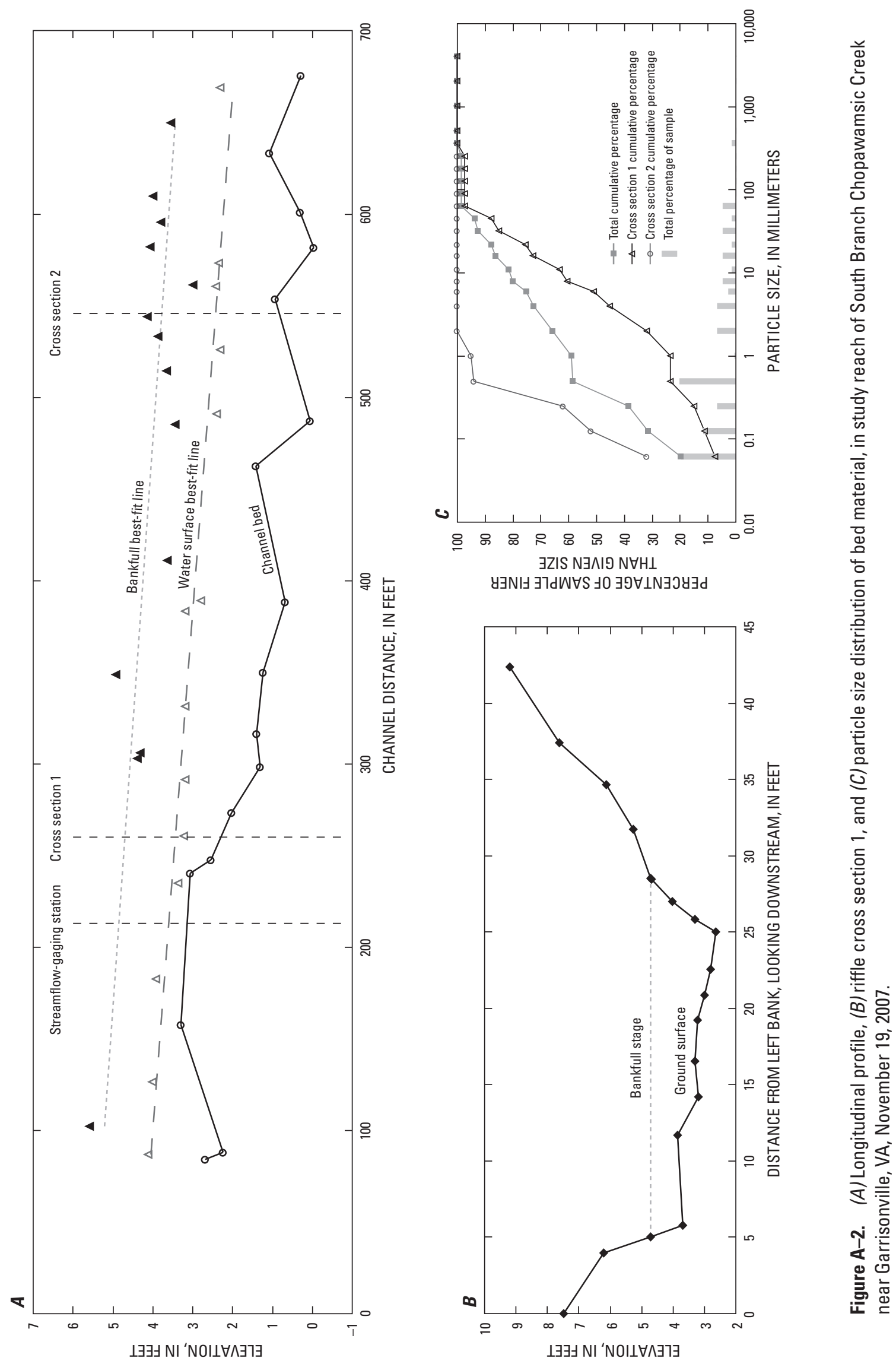


\section{Station 01660400}

\section{Aquia Creek near Garrisonville, VA}

No photo available

LOCATION—Lat $38^{\circ} 29^{\prime} 25^{\prime \prime}$, long $77^{\circ} 26^{\prime} 02^{\prime \prime}$ referenced to North American Datum of 1927, Stafford County, VA, Hydrologic Unit 02070011, on right bank at bridge on State Highway 641, 1.1 mi northwest of Garrisonville, and 3.0 mi upstream from Beaverdam Run.

DRAINAGE AREA-35.0 $\mathrm{mi}^{2}$.

REMARKS - The watershed drains a rapidly developing watershed that is 72.0 percent forested. The channel maintains a consistent geometry throughout the surveyed reach, consisting of moderately steep banks extending up to a nearly flat floodplain on both banks. The main bankfull features in the channel are breaks in bank slope. The bed is mostly coarse sand and gravel with some small cobbles. 

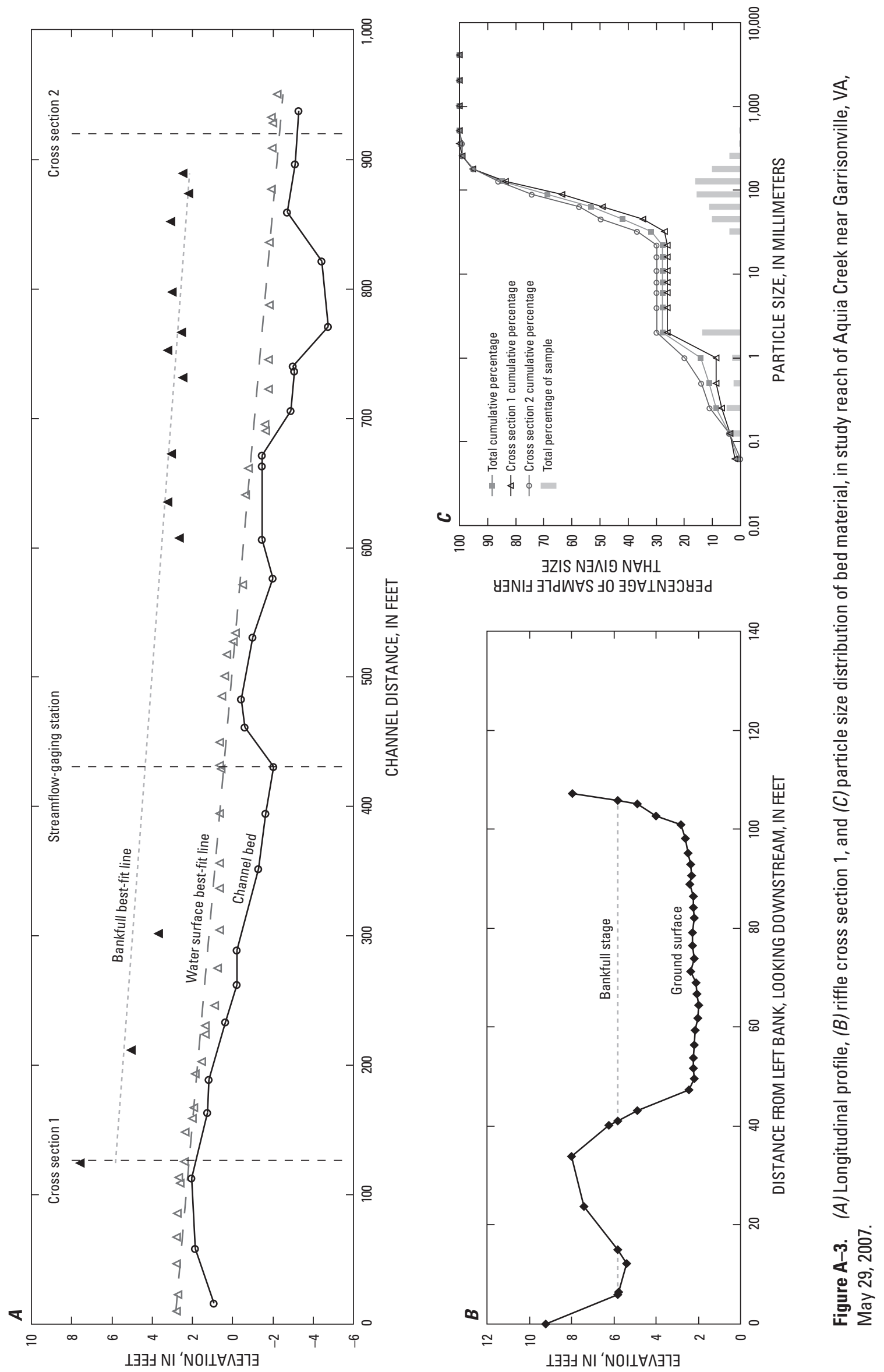


\section{Station 01670300}

\section{Contrary Creek near Mineral, VA}

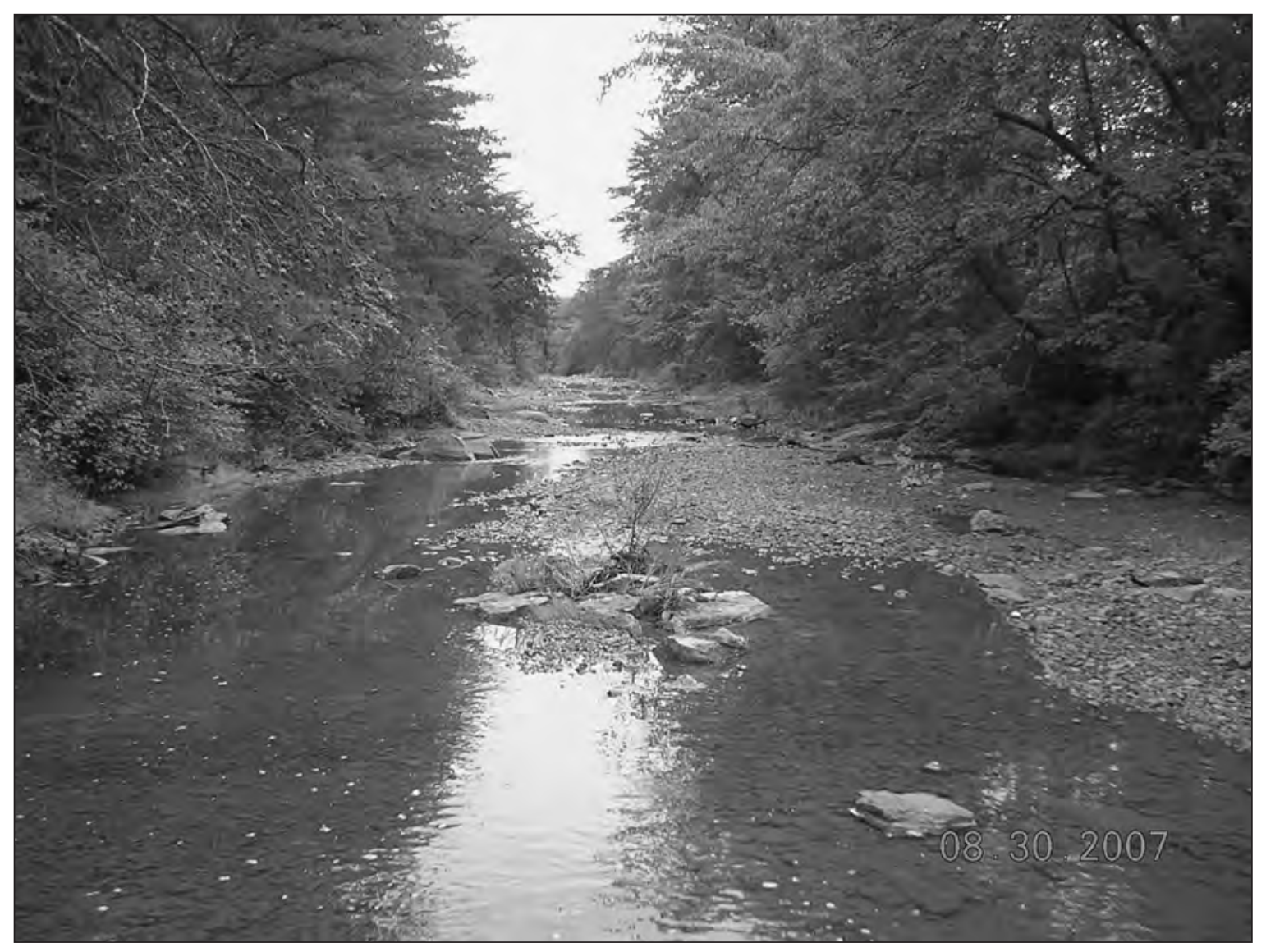

View looking downstream at reach for Contrary Creek near Mineral, VA.

LOCATION - Lat 38 $03^{\prime} 53^{\prime \prime}$, long $77^{\circ} 52^{\prime} 45^{\prime \prime}$ referenced to North American Datum of 1927, Louisa County, VA, Hydrologic Unit 02080106, on left bank $200 \mathrm{ft}$ downstream from bridge on U.S. Highway 522, 4.0 mi northeast of Mineral.

DRAINAGE AREA- $-5.58 \mathrm{mi}^{2}$.

REMARKS - The watershed is 65.6 percent forested. The channel maintains a consistent geometry throughout the surveyed reach, consisting of steep bedrock banks extending up to a nearly flat floodplain on both banks. The main bankfull features in the channel are breaks in bank slope. The bed is mostly sand and gravel with some exposed bedrock. 

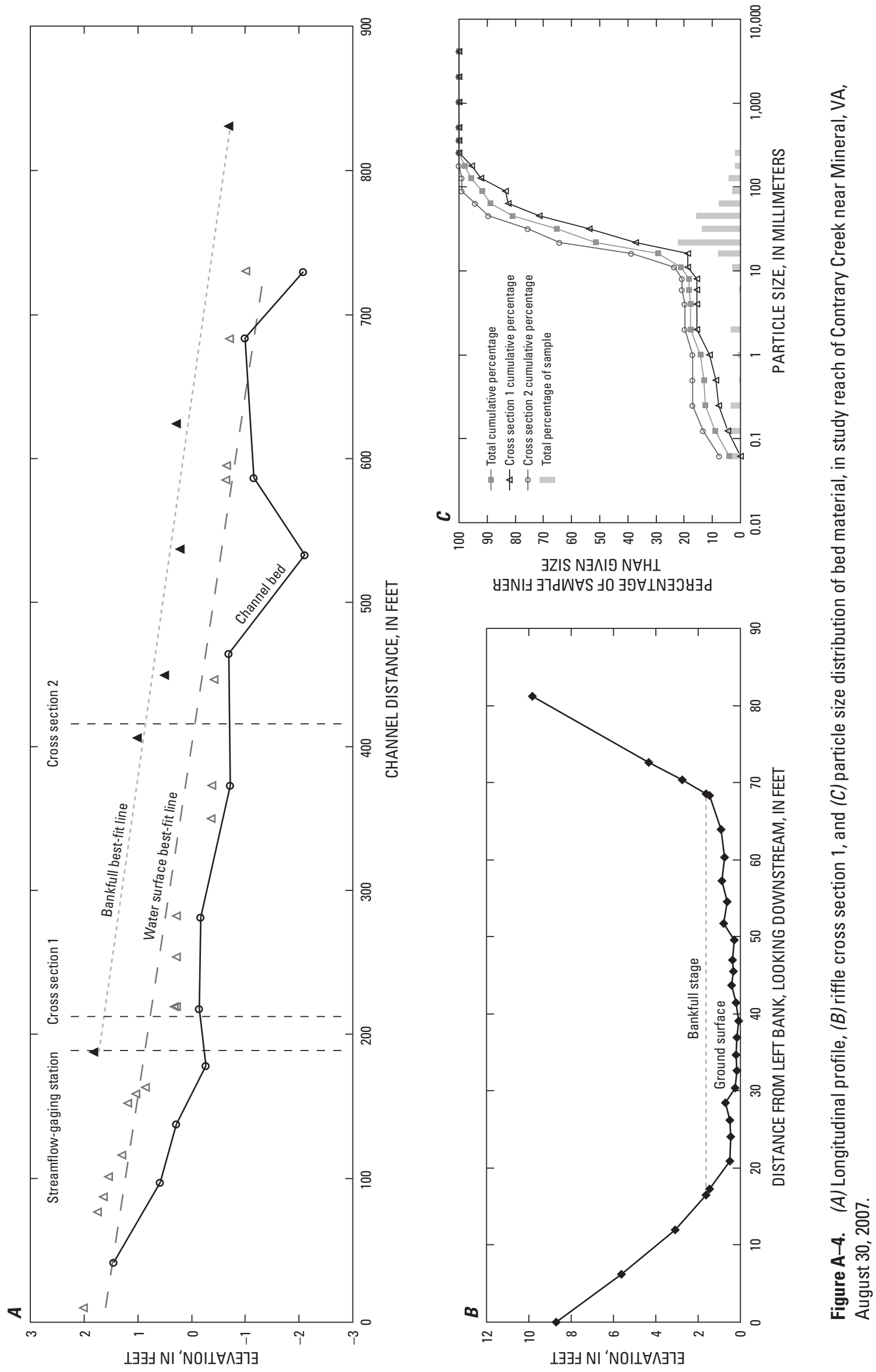


\section{Station 01672400}

\section{South Anna River tributary near Ashland, VA}

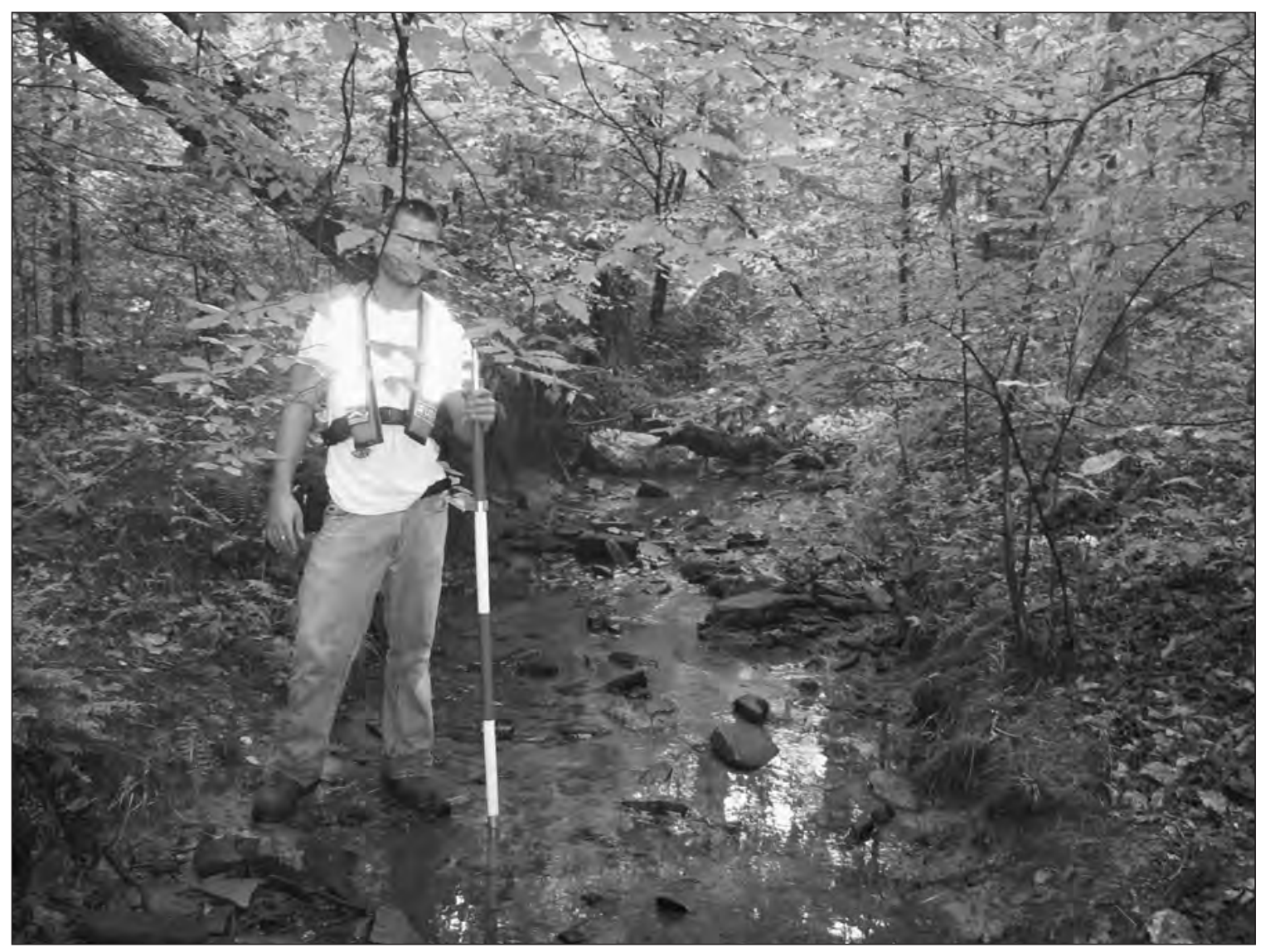

View looking upstream at reach for South Anna River tributary near Ashland, VA.

LOCATION—Lat 37 $48^{\prime} 40^{\prime \prime}$, long $77^{\circ} 34^{\prime} 20^{\prime \prime}$ referenced to North American Datum of 1927, Hanover County, VA, Hydrologic Unit 02080106, just upstream from culvert on State Highway 54, 0.5 mi upstream from mouth, and 5.5 mi northwest of Ashland.

DRAINAGE AREA $-0.33 \mathrm{mi}^{2}$.

REMARKS - The watershed is 58.6 percent forested. The channel maintains a consistent geometry throughout the surveyed reach, consisting of moderately steep banks extending up to a nearly flat, heavily vegetated floodplain on both banks. The main bankfull features in the channel are depositional features. The bed is mostly sand and gravel with larger cobbles in the riffles.

The crest-stage gage is discontinued and has been removed. No reference marks were located to relate the survey to gage datum, so an arbitrary datum was used which eliminated the possibility of determining rated bankfull discharge for this site. 

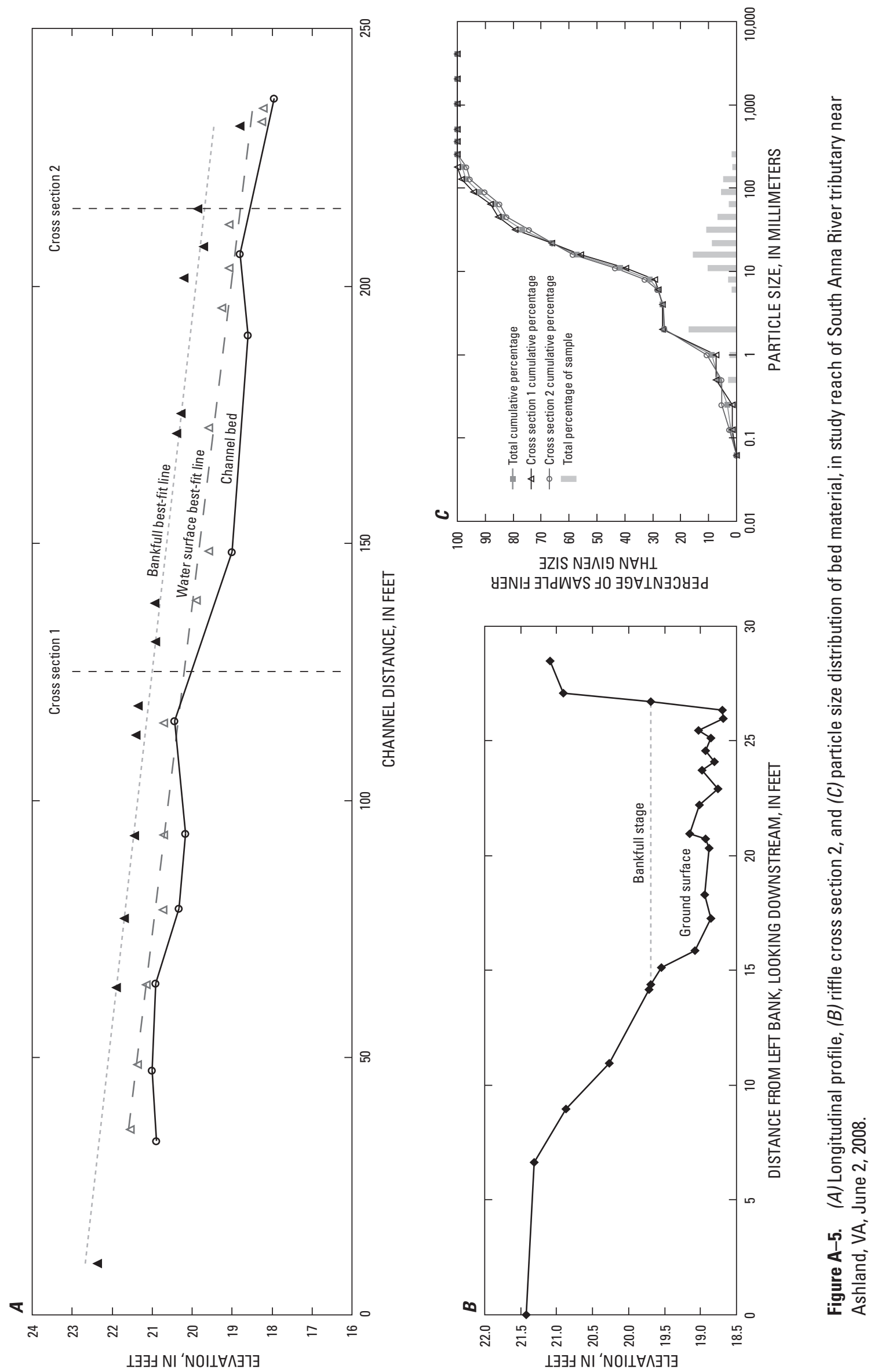


\section{Station 02027700}

\section{Buffalo River tributary near Amherst, VA}

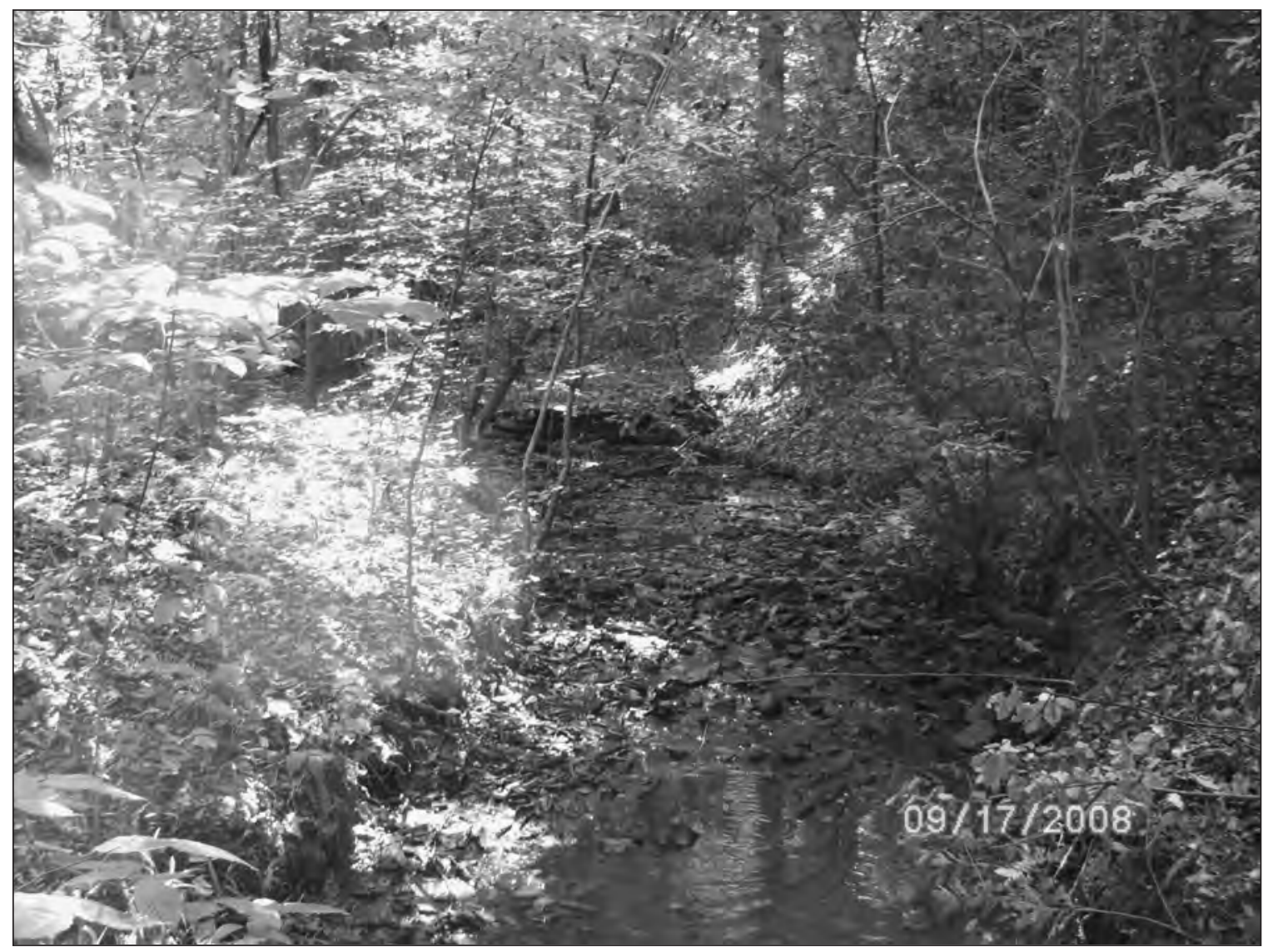

View looking upstream at reach for Buffalo River tributary near Amherst, VA.

LOCATION_Lat 37³3'45", long 7857'35" referenced to North American Datum of 1927, Amherst County, VA, Hydrologic Unit 02080203, on left bank just upstream from culvert on U.S. Highway 60, $0.8 \mathrm{mi}$ upstream from mouth, and $5.2 \mathrm{mi}$ southeast of Amherst.

DRAINAGE AREA- $-0.45 \mathrm{mi}^{2}$.

REMARKS - The watershed is 85.2 percent forested. The channel maintains a consistent geometry throughout the surveyed reach, consisting of moderately steep banks extending up to a nearly flat, lightly vegetated floodplain on both banks. The main bankfull features in the channel are depositional features. The bed is mostly sand and gravel with larger cobbles in the riffles. 

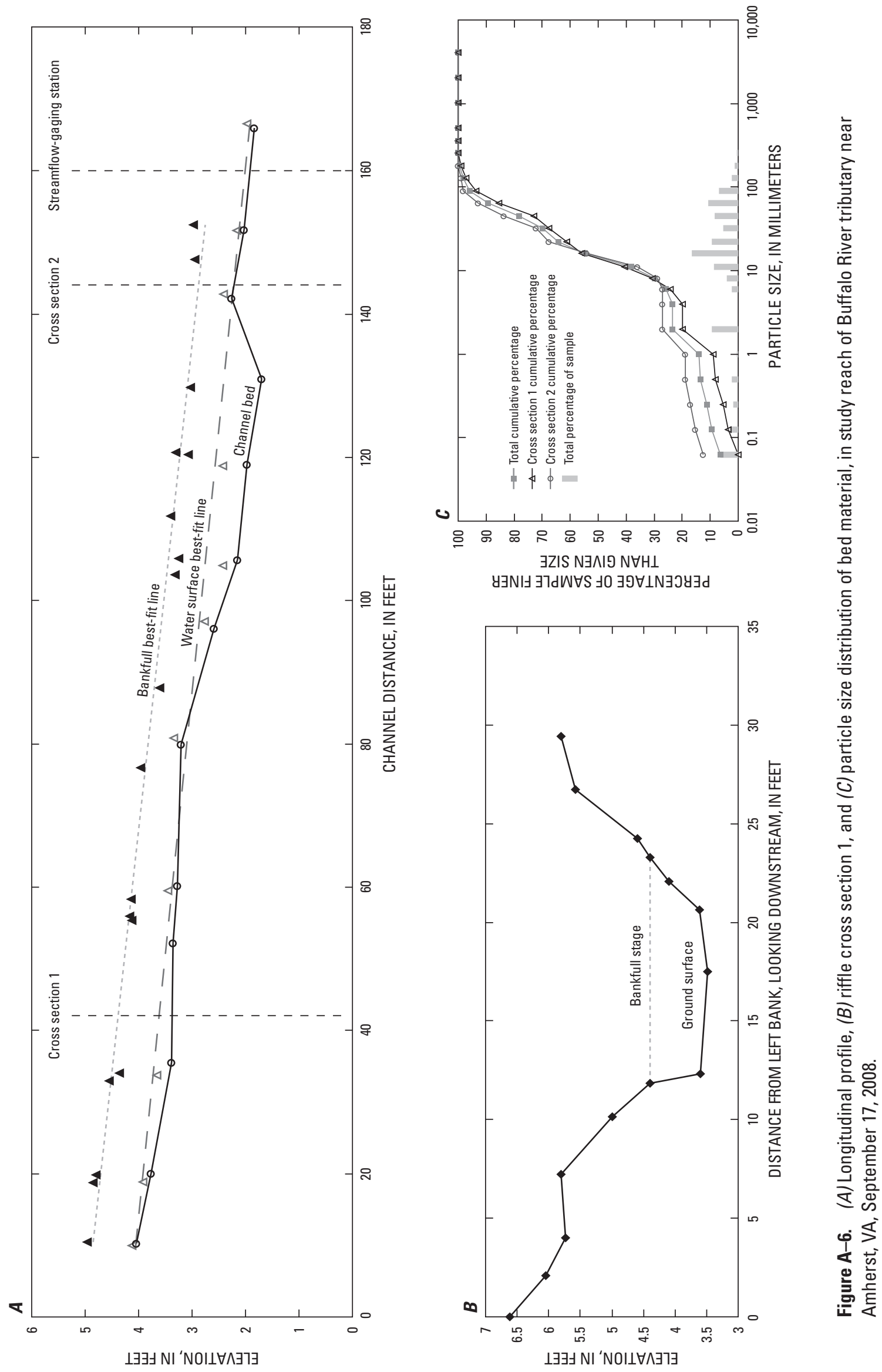


\section{Station 02031000}

\section{Mechums River near White Hall, VA}

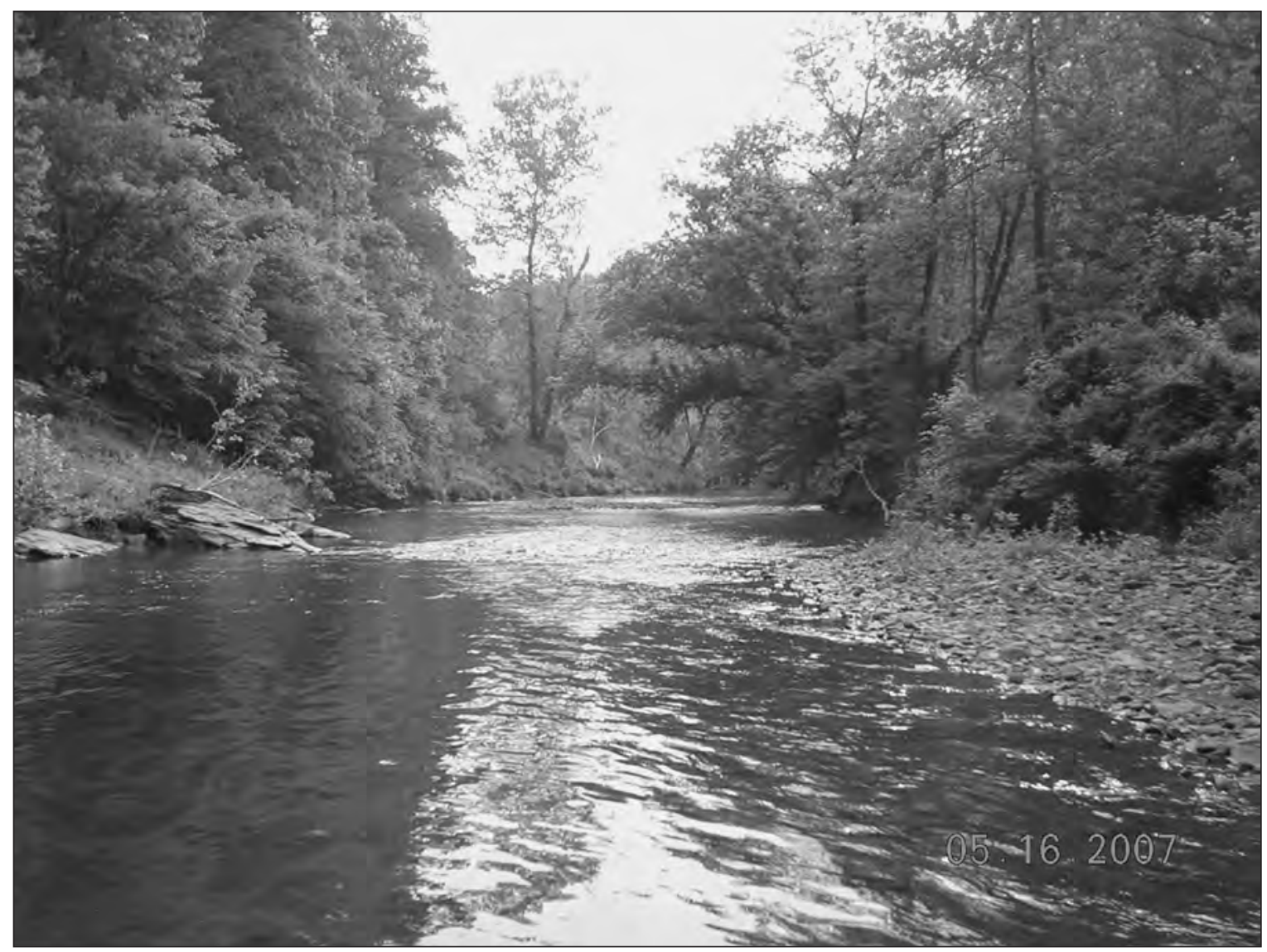

View looking downstream at reach for Mechums River near White Hall, VA.

LOCATION—Lat 38 $06^{\prime} 09^{\prime \prime}$, long $78^{\circ} 35^{\prime} 35^{\prime \prime}$ referenced to North American Datum of 1927, Albemarle County, VA, Hydrologic Unit 02080204, on right bank $20 \mathrm{ft}$ downstream from bridge on State Highway 614, 1.5 mi downstream from Rocky Run, 4.0 mi southeast of White Hall, and 4.9 mi upstream from confluence with Moormans River.

DRAINAGE AREA—95.3 $\mathrm{mi}^{2}$.

REMARKS - The watershed is 63.0 percent forested. The channel maintains a consistent geometry throughout the surveyed reach, consisting of moderately steep banks extending up to a nearly flat, lightly vegetated floodplain on both banks. The surveyed reach is bound upstream and downstream by large bedrock outcrops. The main bankfull features in the channel are depositional features. The bed is mostly sand and gravel with larger cobbles in the riffles. 

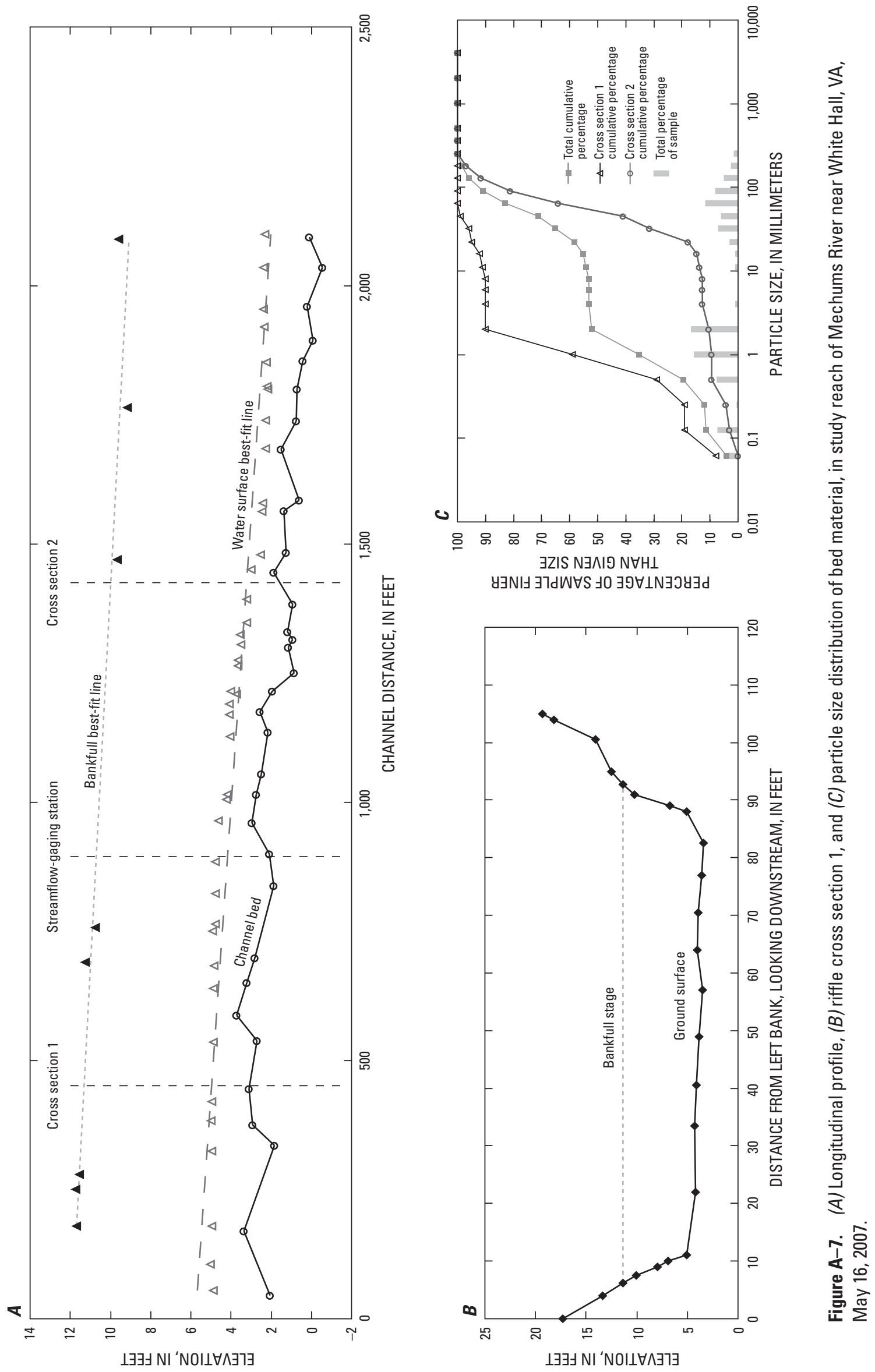


\section{Station 02032640}

\section{North Fork Rivanna River near Earlysville, VA}

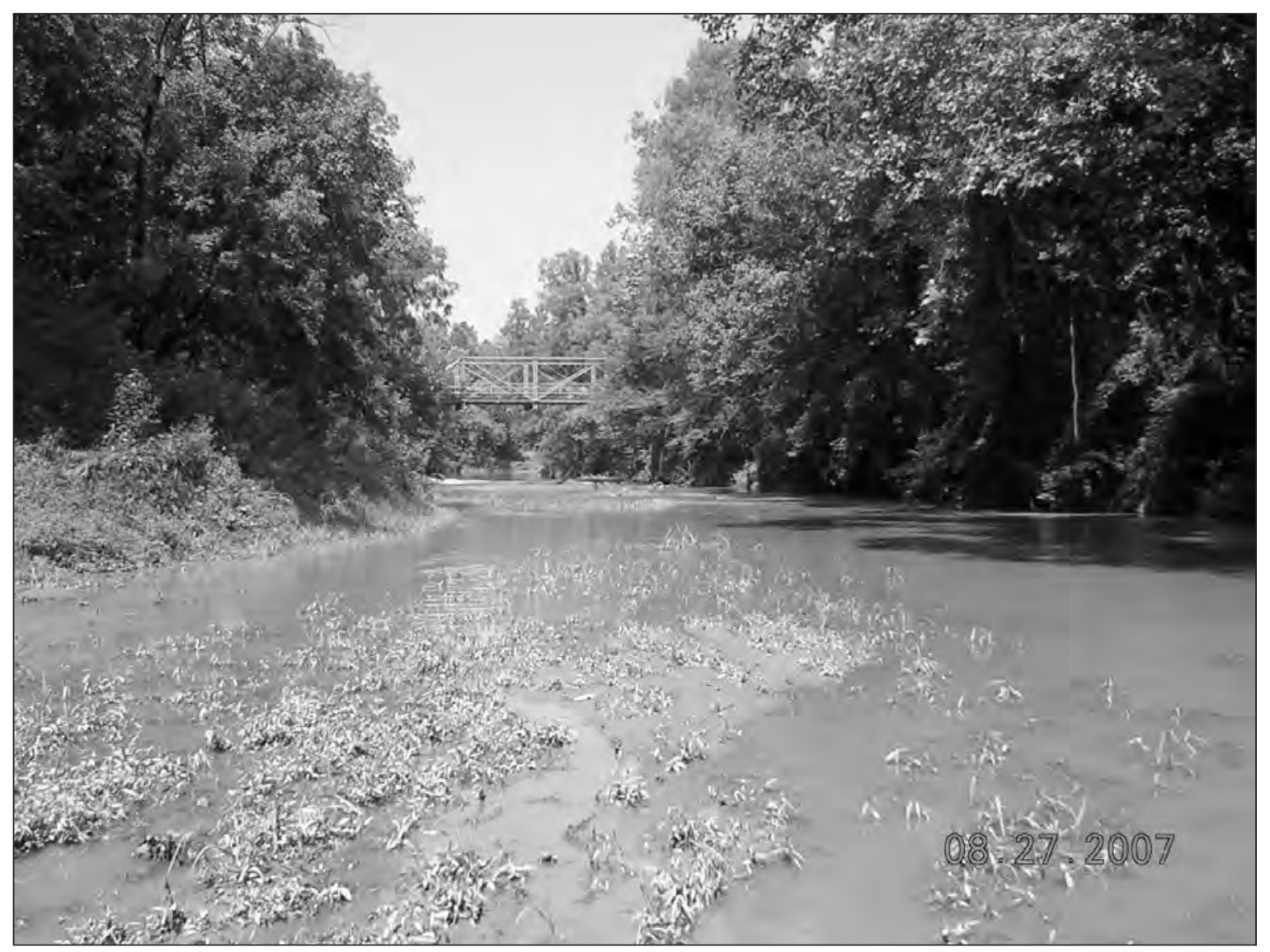

View looking upstream at reach for North Fork Rivanna River near Earlysville, VA.

LOCATION—Lat $38^{\circ} 09^{\prime} 48^{\prime \prime}$, long $78^{\circ} 25^{\prime} 30^{\prime \prime}$ referenced to North American Datum of 1927, Albemarle County, VA, Hydrologic Unit 02080204, on right bank at downstream side of bridge on State Highway 606, 0.4 mi upstream from mouth of Jacobs Run, 1.9 mi downstream from mouth of Marsh Run, and $2.1 \mathrm{mi}$ southeast of Advance Mills.

DRAINAGE AREA-108 $\mathrm{mi}^{2}$.

REMARKS - The watershed is 67.9 percent forested. The channel maintains a consistent geometry throughout the surveyed reach, consisting of moderately steep banks extending up to a nearly flat, moderately vegetated floodplain on both banks. The main bankfull feature in the channel is the top of the bank. The bed is mostly sand and gravel with some exposed bedrock near the bridge crossing. 

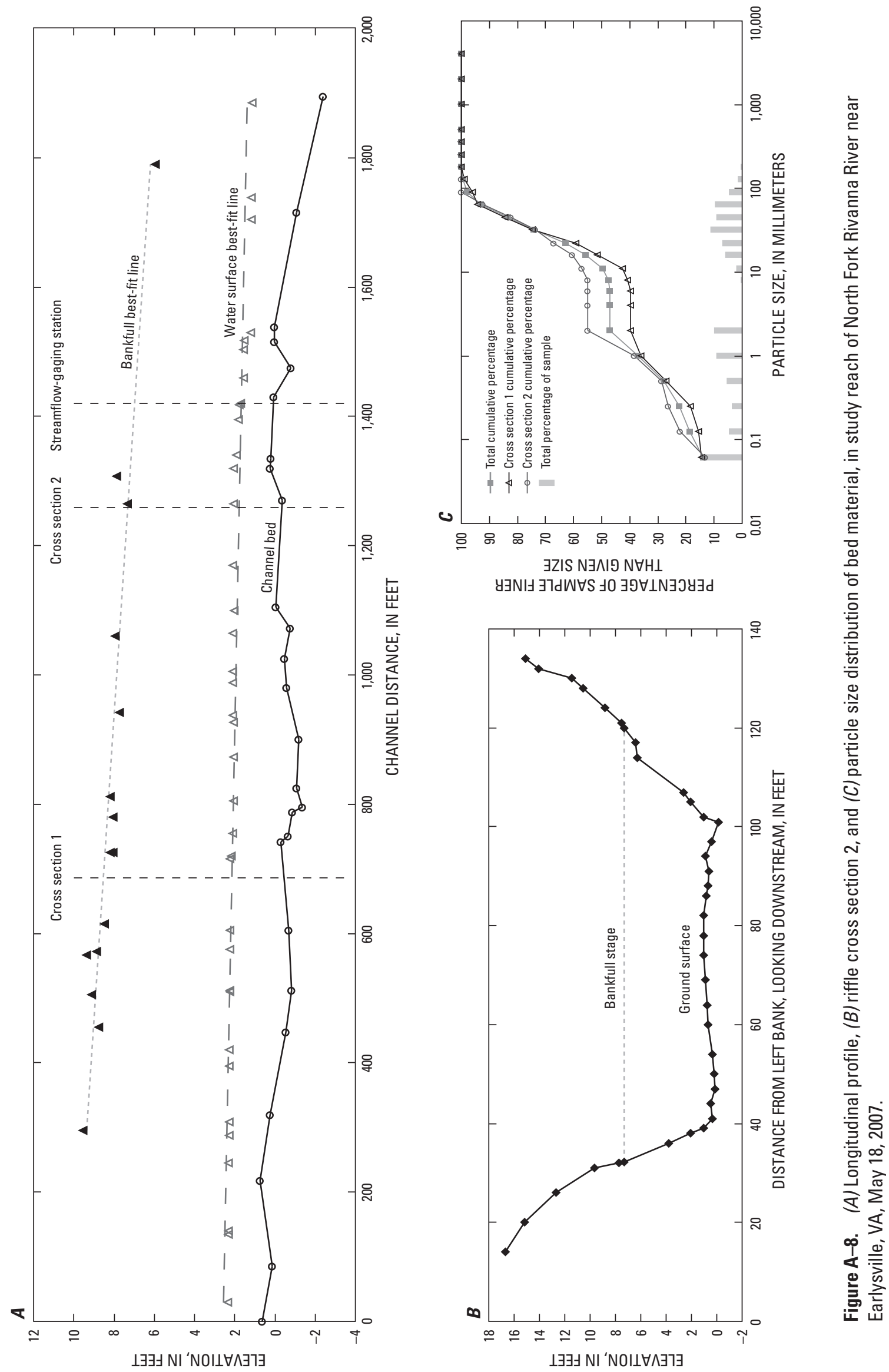


\section{Station 02035400}

\section{Big Lickinghole Creek tributary near Ferncliff, VA}

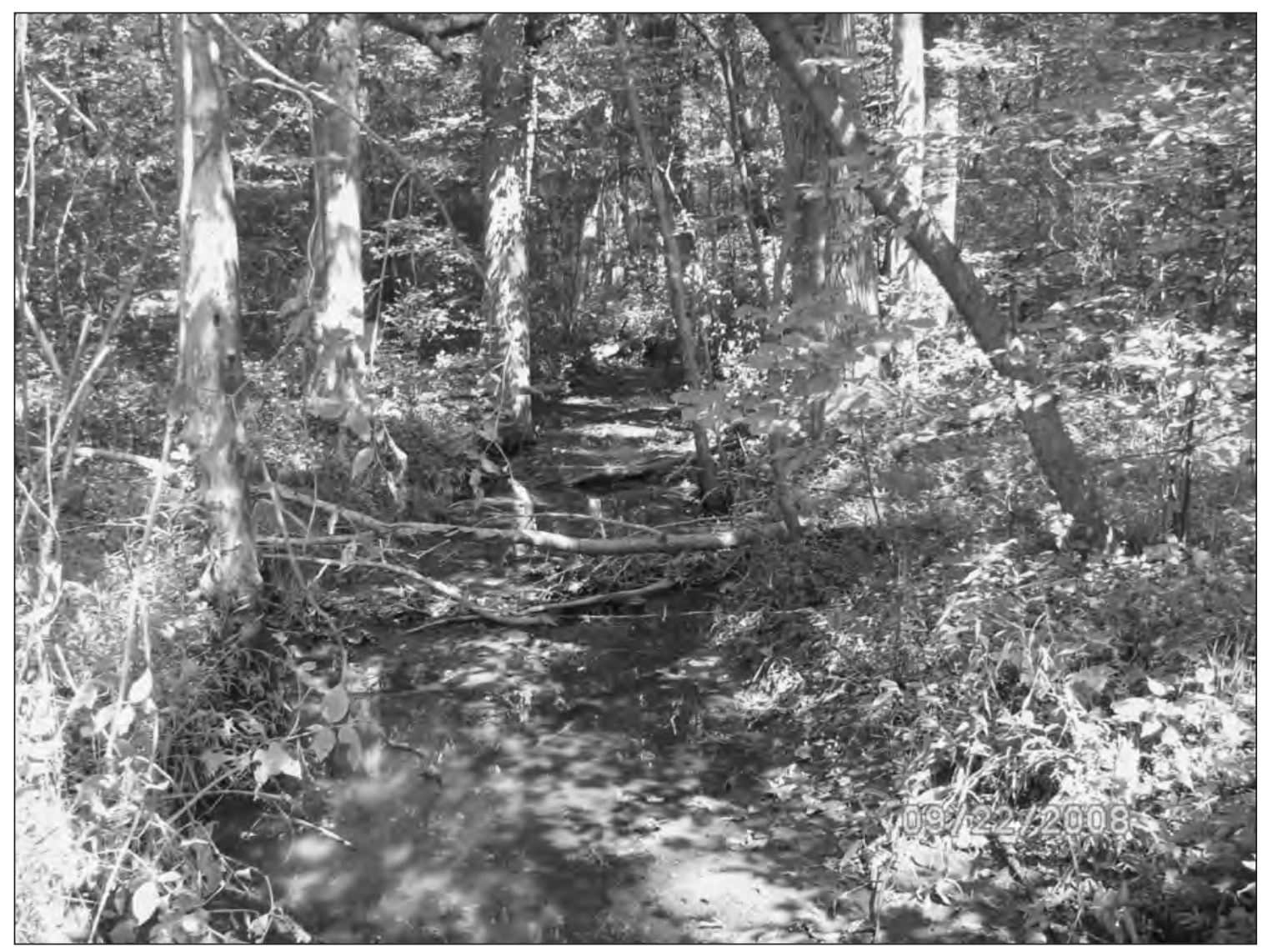

View looking upstream at reach for Big Lickinghole Creek tributary near Ferncliff, VA.

LOCATION_Lat 3749'34", long 7758'23" referenced to North American Datum of 1927, Goochland County, VA, Hydrologic Unit 02080205, at bridge on U.S. Highway 250, 1.5 mi southeast of junction with State Highway 629, and 10.5 mi southeast of Ferncliff.

DRAINAGE AREA-0.54 $\mathrm{mi}^{2}$.

REMARKS - The watershed is 70.2 percent forested. The channel maintains a consistent geometry throughout the surveyed reach, consisting of gently sloping banks extending up to a nearly flat, lightly vegetated floodplain on both banks. The main bankfull features in the channel are depositional features as well as the top of the bank. The bed is mostly sand.

The crest-stage gage is discontinued and has been removed. No reference marks were located to relate the survey to gage datum, so an arbitrary datum was used which eliminated the possibility of determining rated bankfull discharge for this site. 

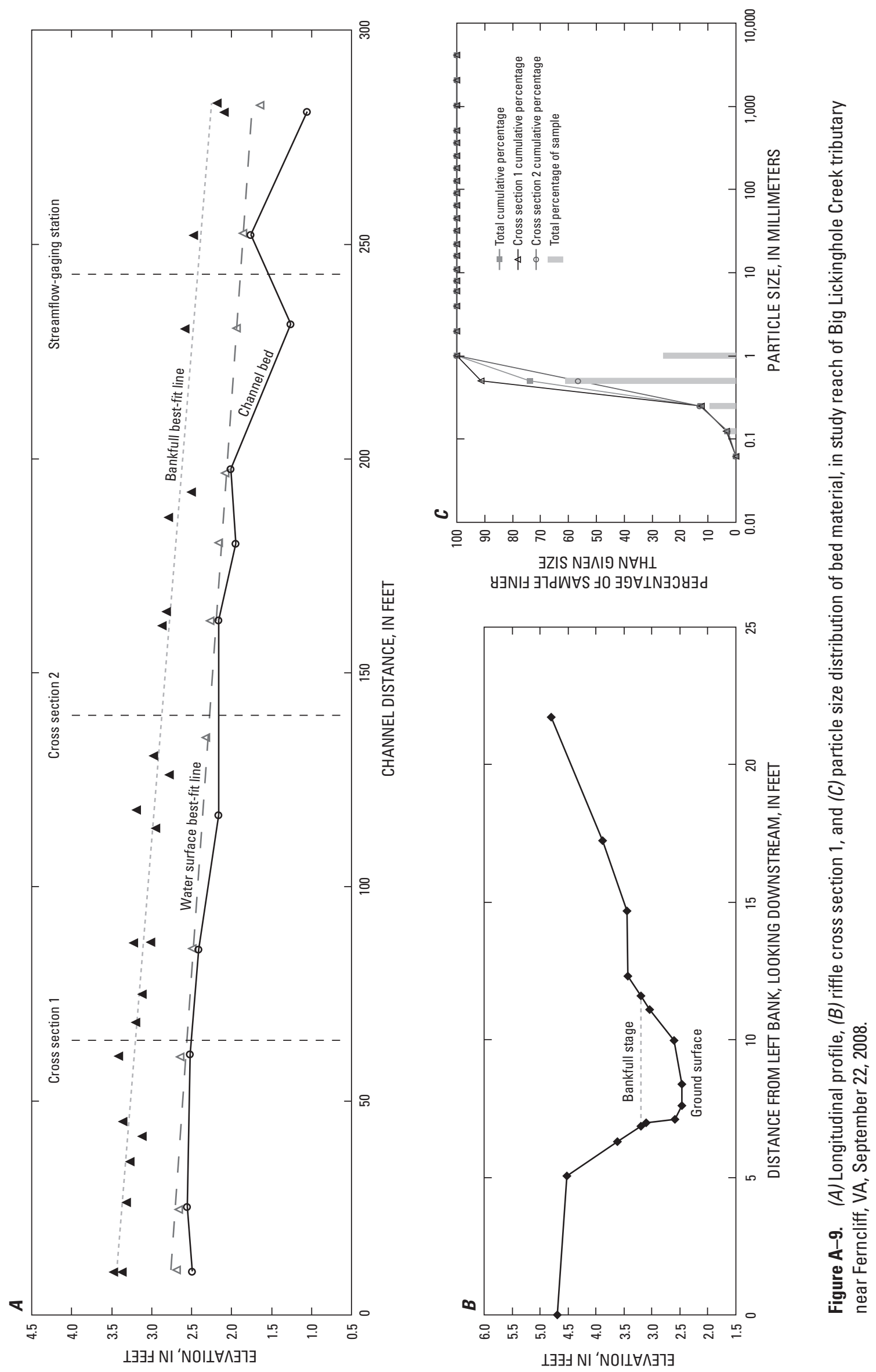


\section{Station 02036500}

Fine Creek at Fine Creek Mills, VA

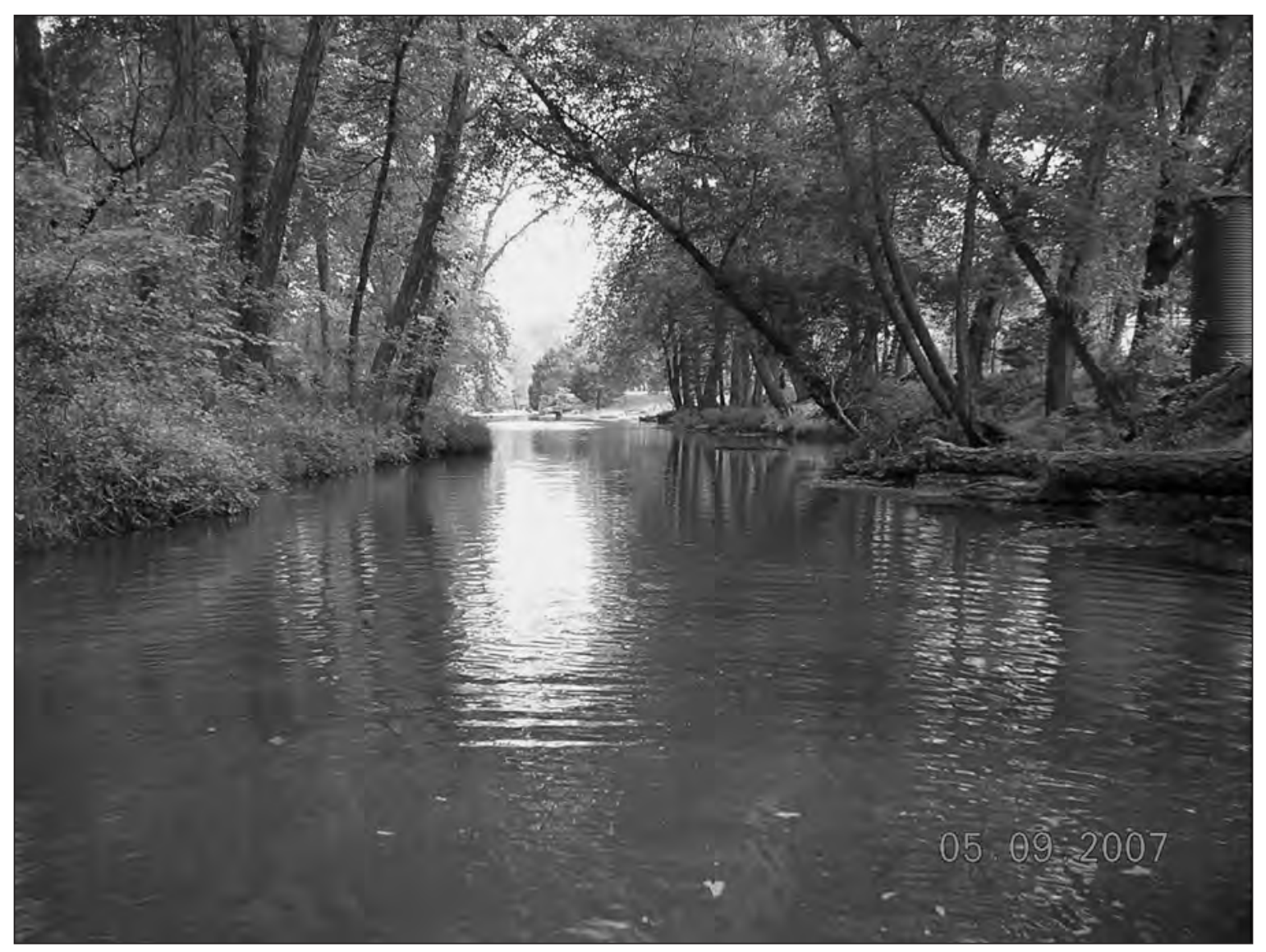

View looking downstream at reach for Fine Creek at Fine Creek Mills, VA.

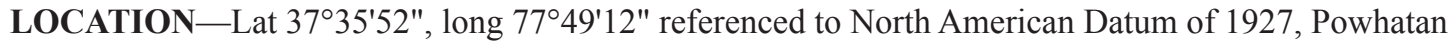
County, VA, Hydrologic Unit 02080205, on right bank 75 ft downstream from bridge on State Highway 711 at Fine Creek Mills, 0.8 mi upstream from mouth, and 6.7 mi northeast of Powhatan.

DRAINAGE AREA-22.4 mi².

REMARKS - The watershed is 70.2 percent forested. The channel maintains a consistent geometry throughout the surveyed reach, consisting of gently sloping banks extending up to a nearly flat, lightly vegetated floodplain on both banks. The main bankfull features in the channel are breaks in bank slope. The bed is mostly bedrock with some sand and gravel deposited between outcrops. 

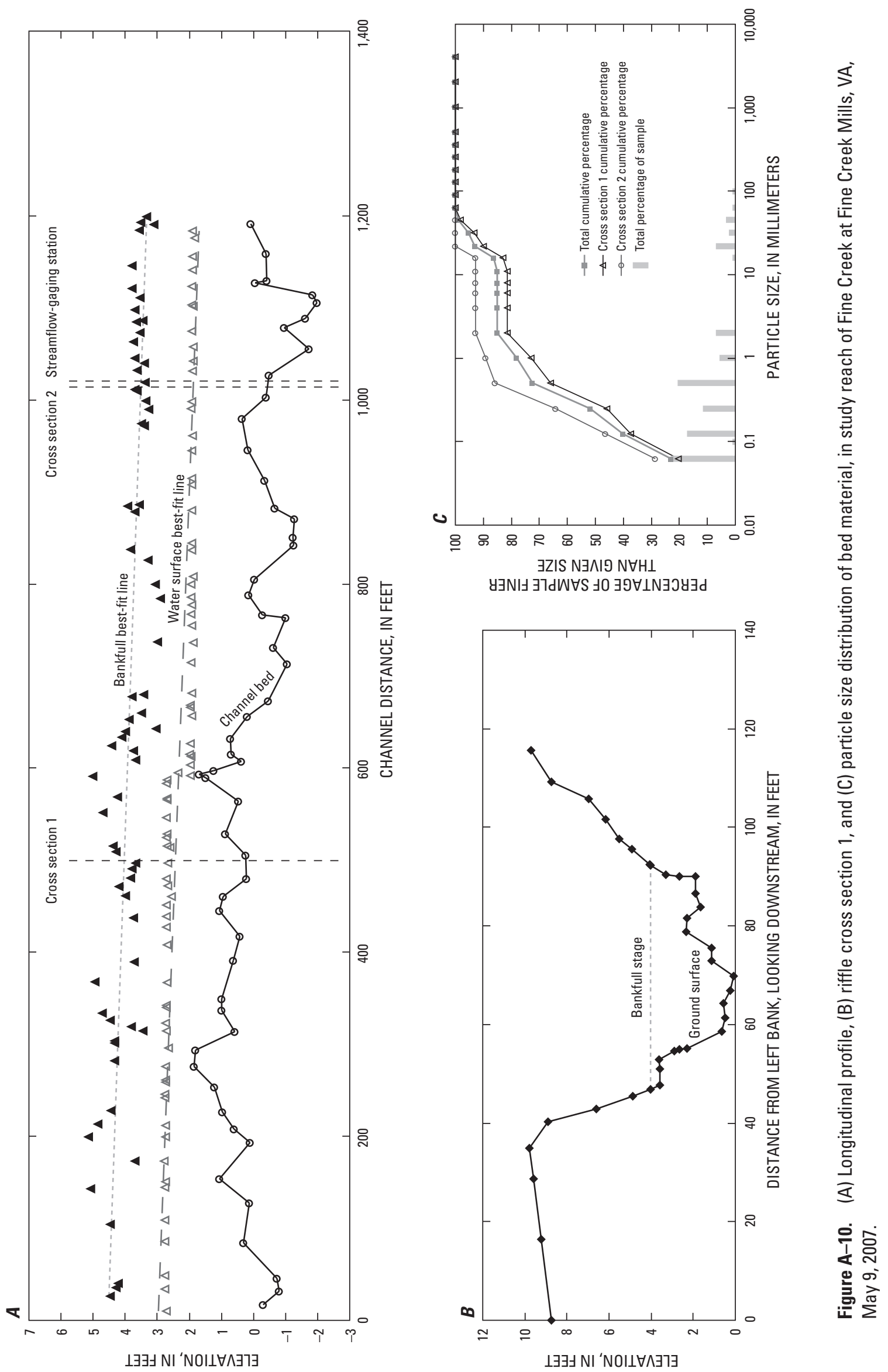


\section{Station 02038845}

\section{North Holiday Creek near Toga, VA}

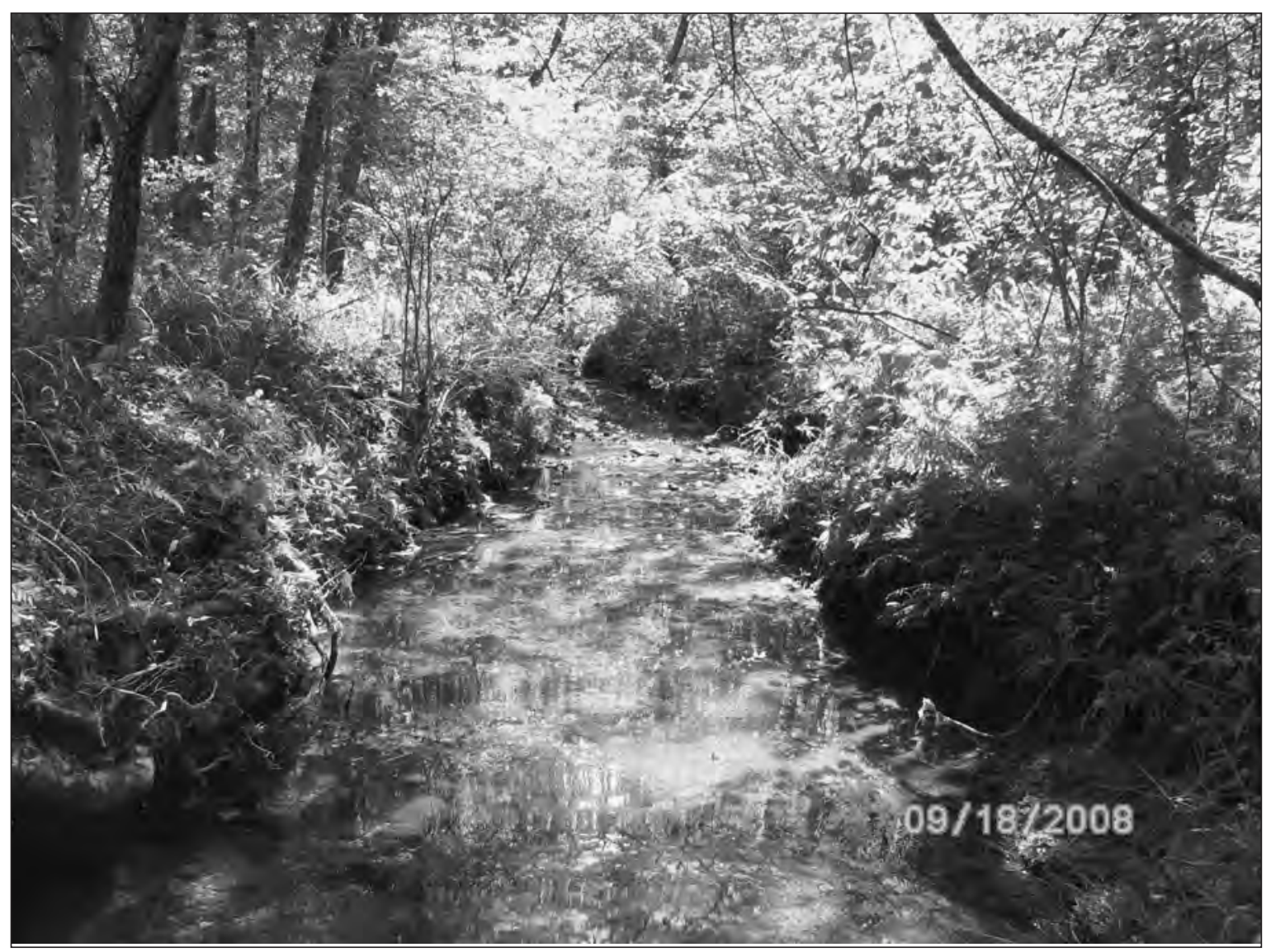

View looking downstream at reach for North Holiday Creek near Toga, VA.

LOCATION_Lat 37²6'09", long 7840'04" referenced to North American Datum of 1927, Buckingham County, VA, Hydrologic Unit 02080203, on left bank $18 \mathrm{ft}$ upstream from State forest road 2307, $1.0 \mathrm{mi}$ upstream from confluence with Holiday Creek, and 4.5 mi south-southwest of Toga.

DRAINAGE AREA-1.35 $\mathrm{mi}^{2}$.

REMARKS - The watershed is located in the Appomattox State Forest and is 78.0 percent forested. The channel maintains a consistent geometry throughout the surveyed reach, consisting of gently sloping banks extending up to a nearly flat, lightly vegetated floodplain on the left bank and more densely vegetated right bank floodplain. The main bankfull features in the channel are depositional features. The bed is mostly sand and gravel with some small cobbles. 

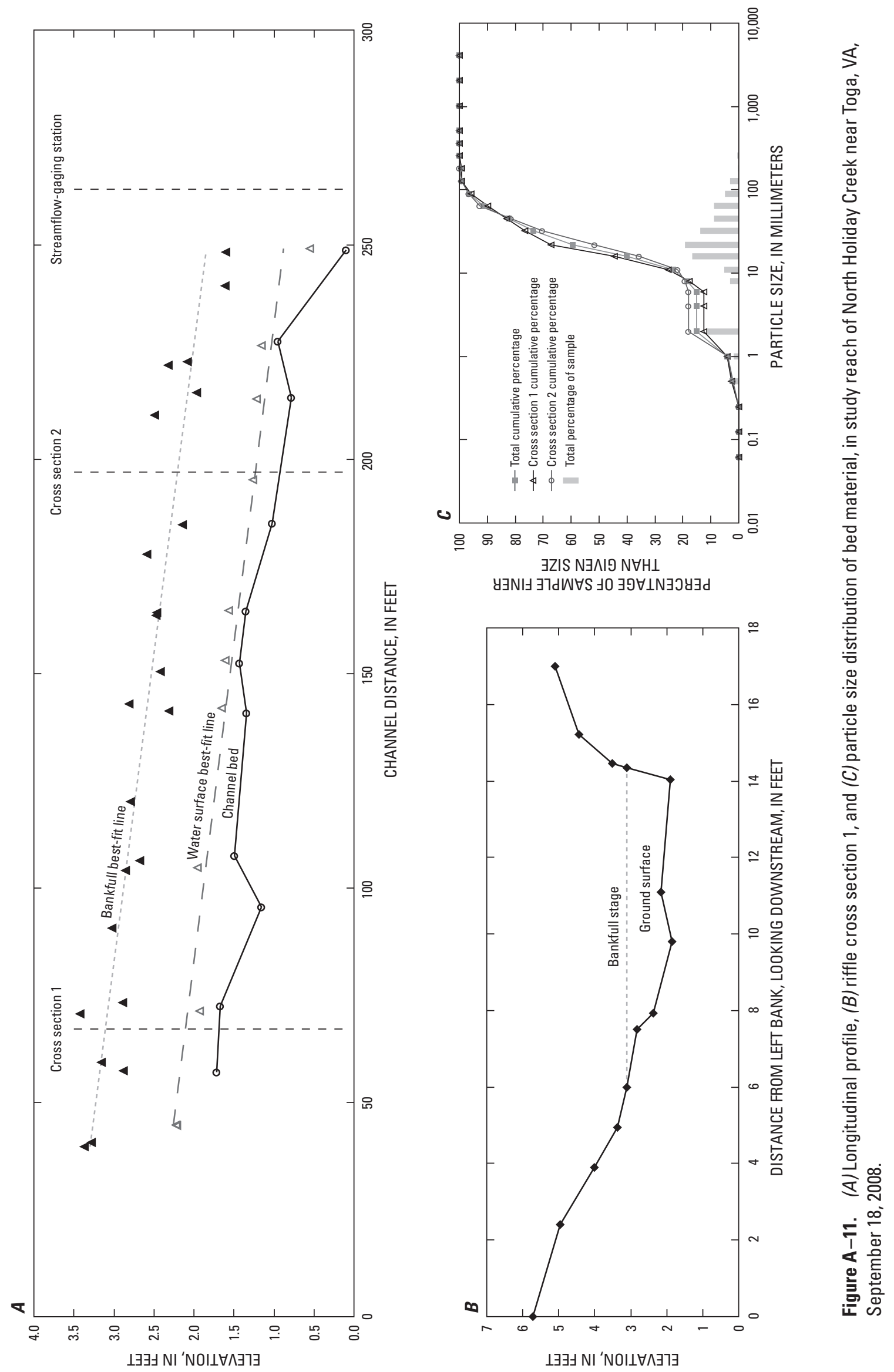


\section{Station 02039000}

\section{Buffalo Creek near Hampden Sydney, VA}

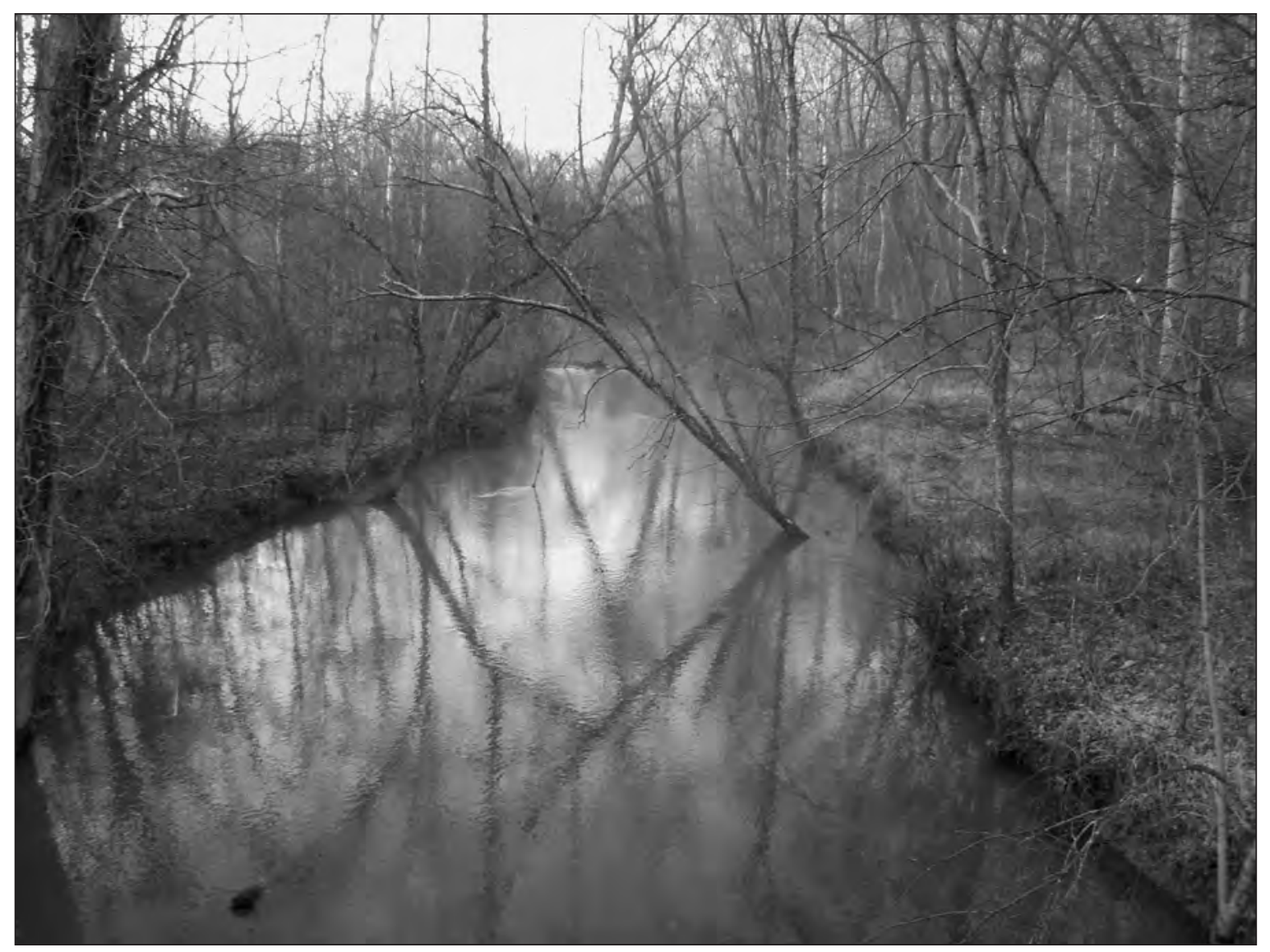

View looking upstream at reach for Buffalo Creek near Hampden Sydney, VA.

LOCATION — Lat $37^{\circ} 15^{\prime} 25^{\prime \prime}$, long $78^{\circ} 29^{\prime} 12^{\prime \prime}$ referenced to North American Datum of 1927, Prince Edward County, VA, Hydrologic Unit 02080207, on left bank $100 \mathrm{ft}$ upstream from bridge on State Highway 658, $0.8 \mathrm{mi}$ upstream from Locket Creek, 2.0 mi northwest of Hampden Sydney, and $6.0 \mathrm{mi}$ southwest of Farmville.

DRAINAGE AREA $-69.6 \mathrm{mi}^{2}$.

REMARKS-The watershed is 66.5 percent forested. The channel maintains a consistent U-shaped geometry throughout the surveyed reach, consisting of steep banks extending up to a nearly flat, lightly vegetated floodplain on both banks. The top of the bank is identified as the bankfull feature. The bed is mostly sand. 

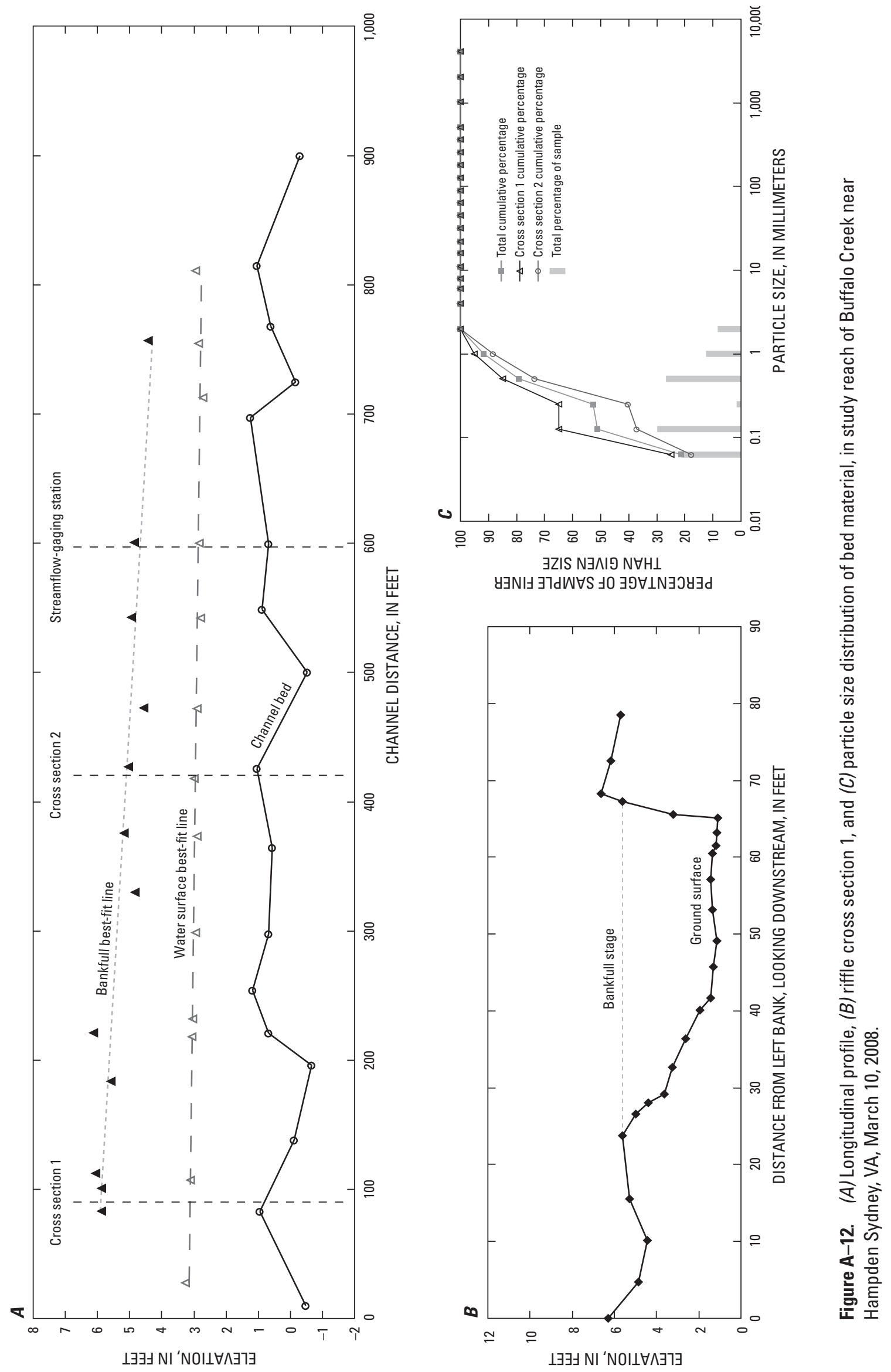


\section{Station 02044200}

Falls Creek tributary near Victoria, VA

No photo available

LOCATION—Lat $37^{\circ} 02^{\prime} 04^{\prime \prime}$, long $78^{\circ} 10^{\prime} 26^{\prime \prime}$ referenced to North American Datum of 1927, Lunenburg County, VA, Hydrologic Unit 03010201, at upstream end of culvert on State Highway 49, 3.6 mi northeast of Victoria.

DRAINAGE AREA-0.37 $\mathrm{mi}^{2}$.

REMARKS - The watershed is 48.4 percent forested. The channel maintains a consistent geometry throughout the surveyed reach, consisting of gently sloping banks extending up to a nearly flat, densely vegetated floodplain on both banks. The primary bankfull feature is a break in the bank slope. The bed is mostly sand and gravel with some small cobbles.

The survey continued through the location of the crest-stage gage but the water surface and bankfull elevations were not used in the vicinity of the gage due to the drop through the culvert. The bankfull stage at the gage was determined from this data, but the modeled discharge used the data collected below the road. 

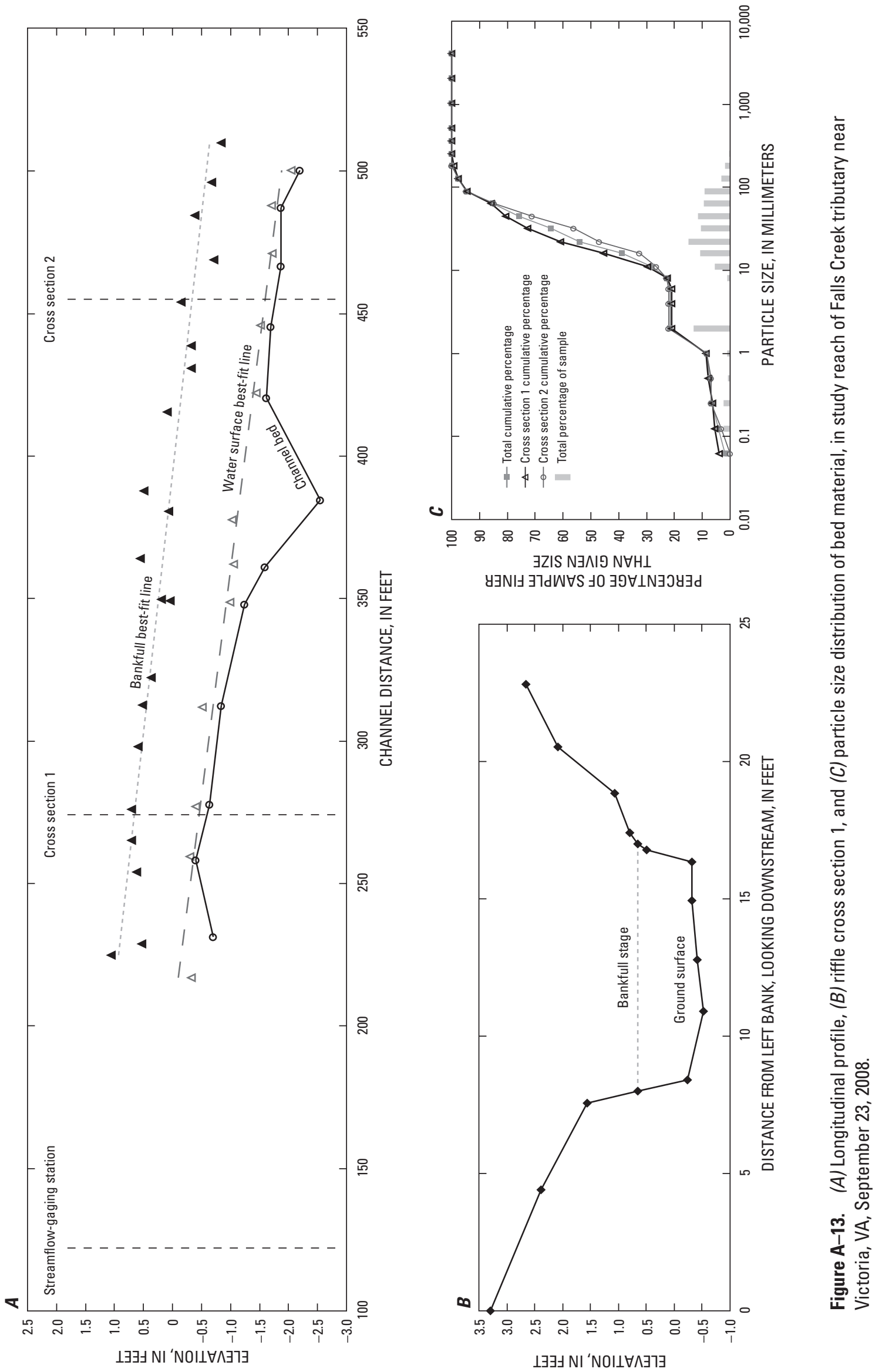


\section{Station 02050500}

\section{North Meherrin River near Keysville, VA}

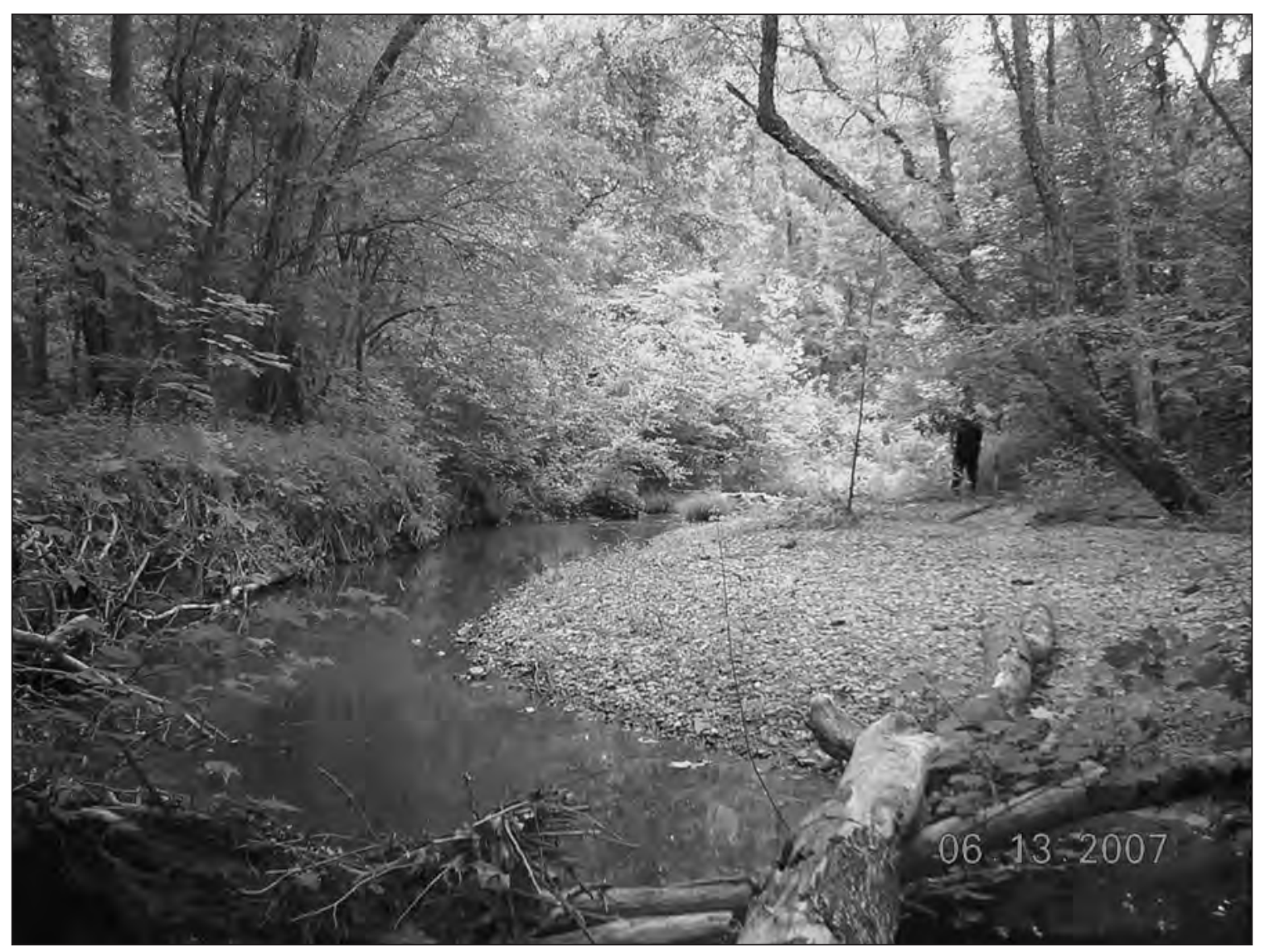

View looking upstream at reach for North Meherrin River near Keysville, VA.

LOCATION—Lat $37^{\circ} 03^{\prime} 05^{\prime \prime}$, long $78^{\circ} 25^{\prime} 20^{\prime \prime}$ referenced to North American Datum of 1927, Charlotte County, VA, Hydrologic Unit 03010204, on left upstream abutment on State Highway 687, 3.3 mi upstream from Owl Creek, and 3.5 mi northeast of Keysville.

DRAINAGE AREA-9.20 $\mathrm{mi}^{2}$.

REMARKS-The watershed is 60.2 percent forested. The channel maintains a consistent geometry throughout the surveyed reach, consisting of gently sloping banks extending up to a nearly flat, densely vegetated floodplain on both banks. The main bankfull features in the channel are depositional features. The bed is mostly sand and gravel with some small cobbles.

The crest-stage gage is discontinued and has been removed. No reference marks were located to relate the survey to gage datum, so an arbitrary datum was used which eliminated the possibility of determining rated bankfull discharge for this site. 

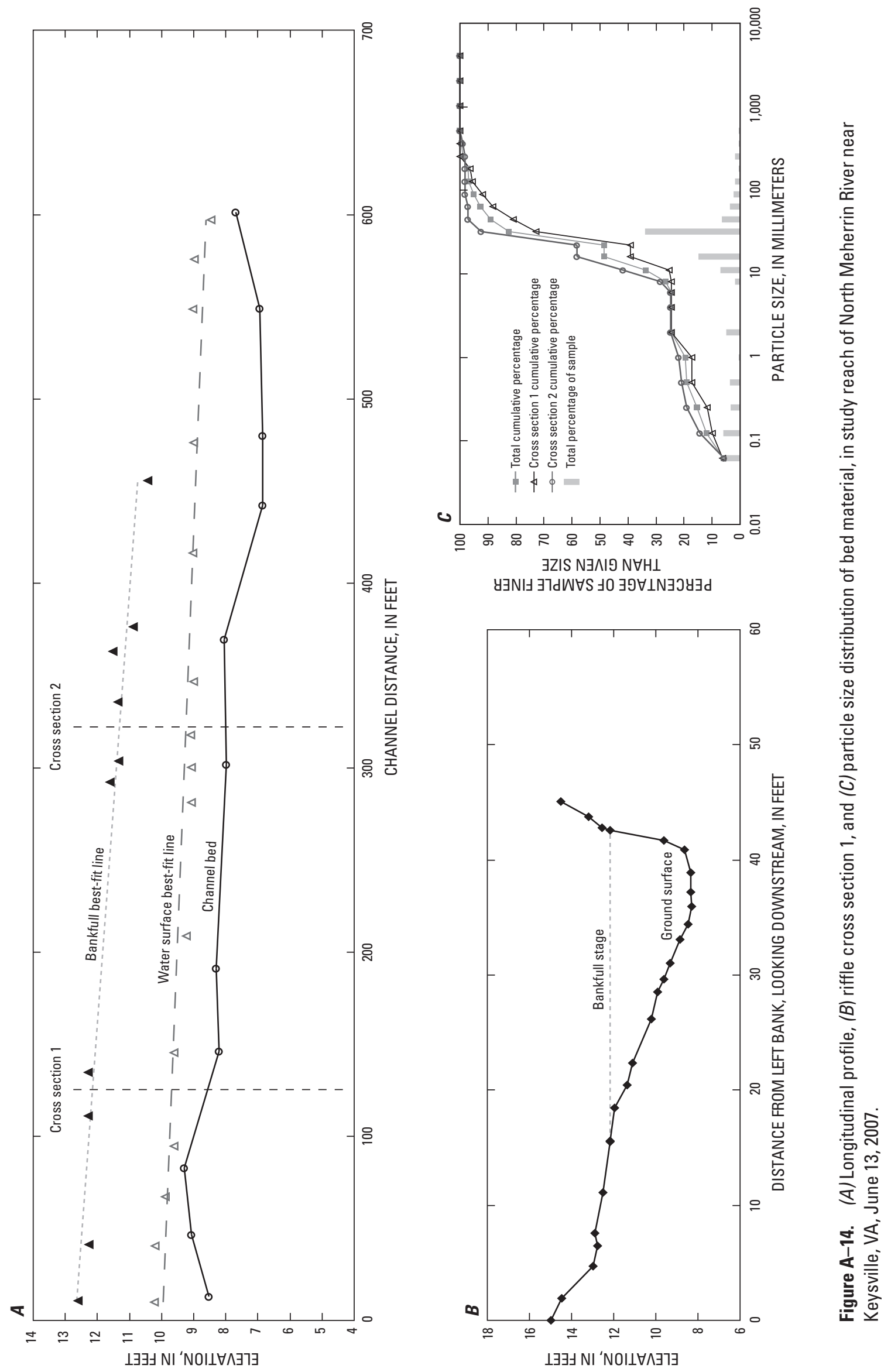


\section{Station 02071530}

\section{Smith River at Smith River Church near Woolwine, VA}

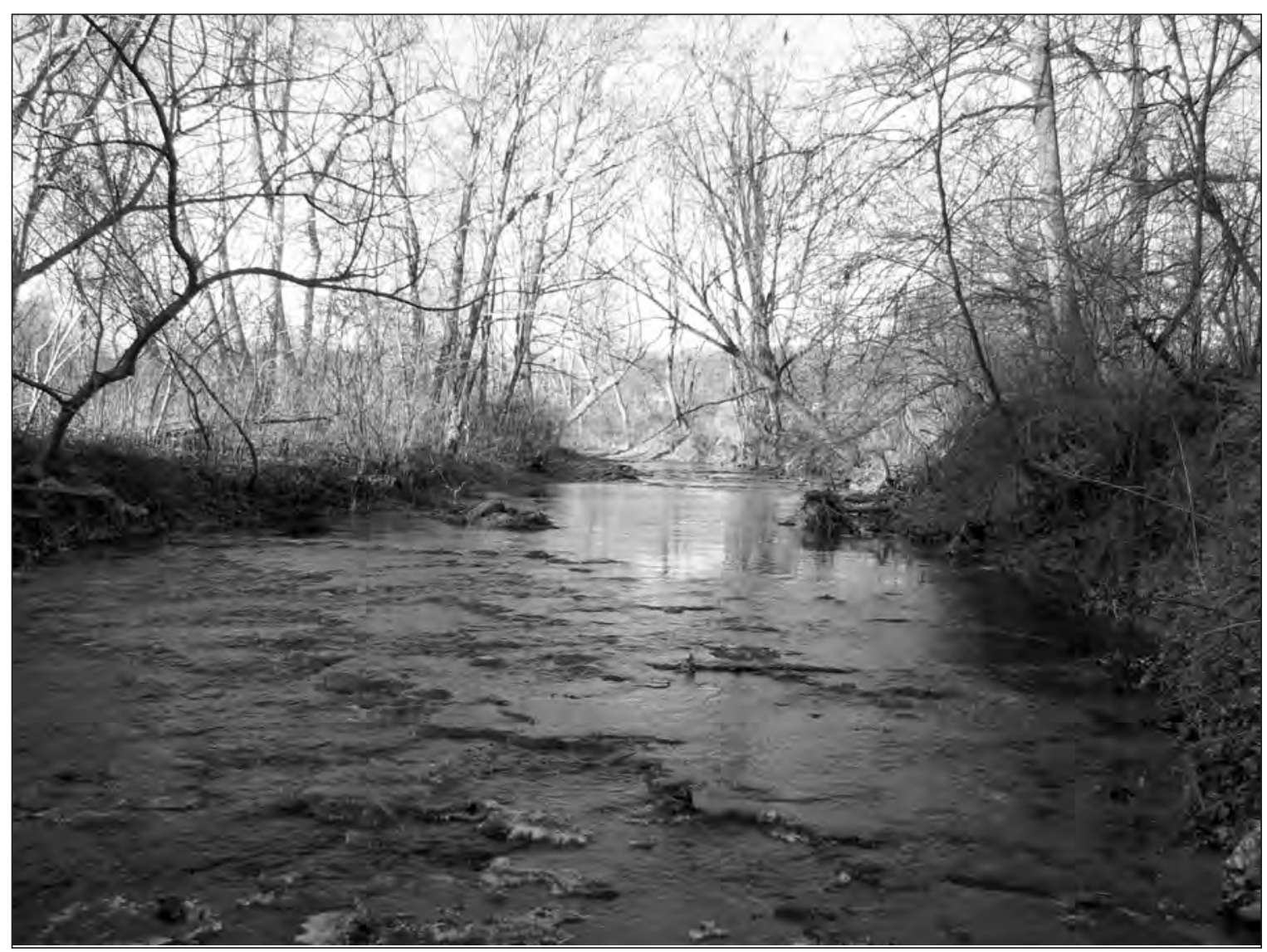

View looking upstream at reach for Smith River at Smith River Church near Woolwine, VA.

LOCATION_Lat 3646'42", long 80¹4'58" referenced to North American Datum of 1927, Patrick County, VA, Hydrologic Unit 03010103, on left bank $10 \mathrm{ft}$ downstream from bridge on State Highway 708, $1.9 \mathrm{mi}$ southeast of Woolwine, and 29 mi upstream from Philpott Dam.

DRAINAGE AREA-26.3 $\mathrm{mi}^{2}$.

REMARKS - The watershed is 78.8 percent forested. The channel maintains a consistent geometry throughout the surveyed reach, consisting of gently sloping banks extending up to a nearly flat, lightly vegetated floodplain on both banks. The primary bankfull features are depositional features on both banks. The bed is mostly sand, gravel, and cobbles. 

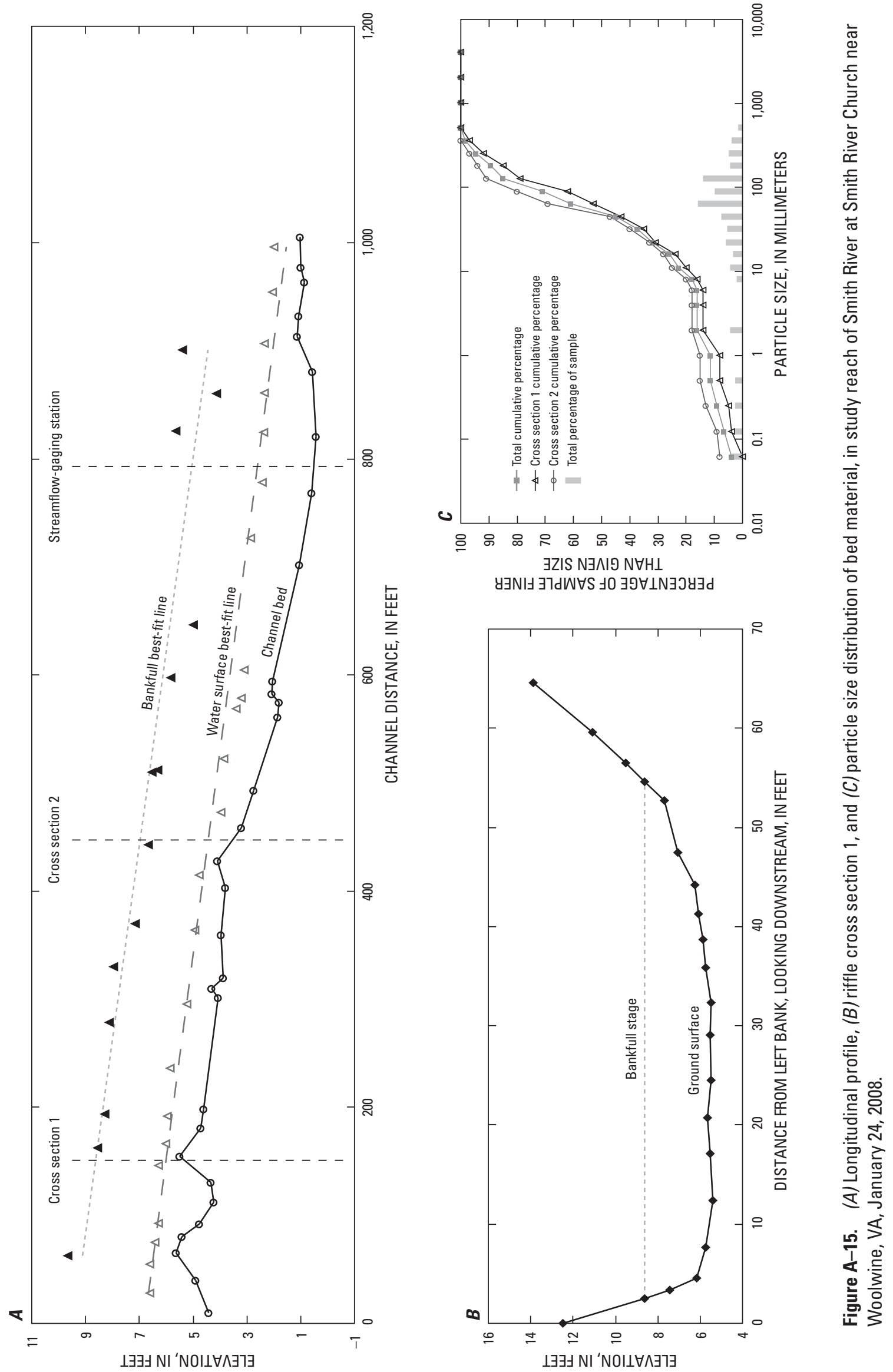


\section{Station 02074500}

\section{Sandy River near Danville, VA}

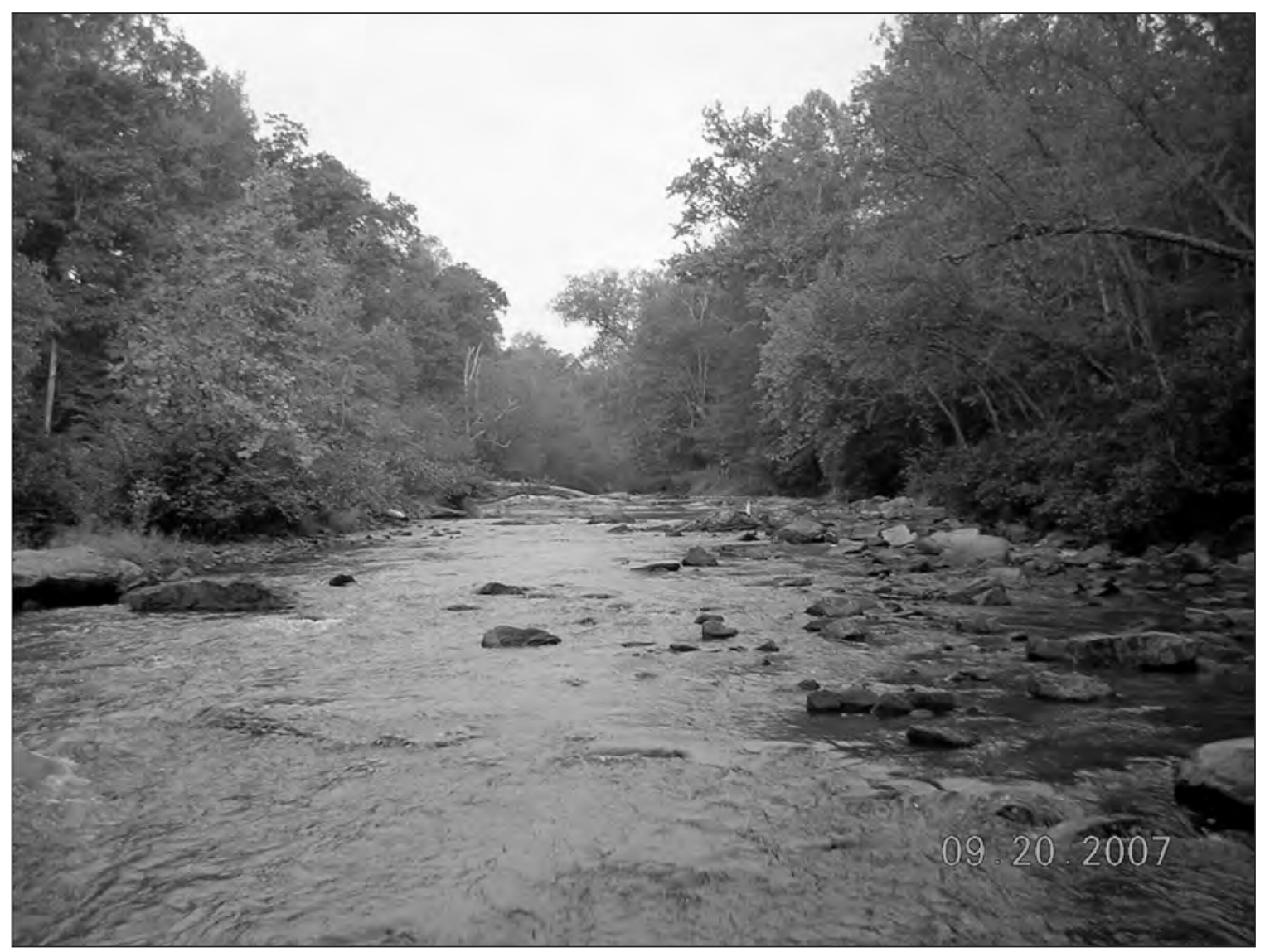

View looking upstream at reach for Sandy River near Danville, VA.

LOCATION—Lat $36^{\circ} 37^{\prime} 10^{\prime \prime}$, long 79³0'16" referenced to North American Datum of 1927, Pittsylvania County, VA, Hydrologic Unit 03010103, on right bank $200 \mathrm{ft}$ downstream from Hickory Forest Creek, $400 \mathrm{ft}$ upstream from bridge on State Highway 863 between Callahans Store and Mount Cross, 5.5 mi northwest of western city limits of Danville, and 5.8 mi upstream from mouth.

DRAINAGE AREA-111 $\mathrm{mi}^{2}$.

REMARKS - The watershed is 58.6 percent forested. The channel maintains a consistent geometry throughout the surveyed reach, consisting of gently sloping banks extending up to a nearly flat, densely vegetated floodplain on both banks. The primary bankfull feature is the top of the bank. The bed is mostly cobbles with some sand and gravel. 

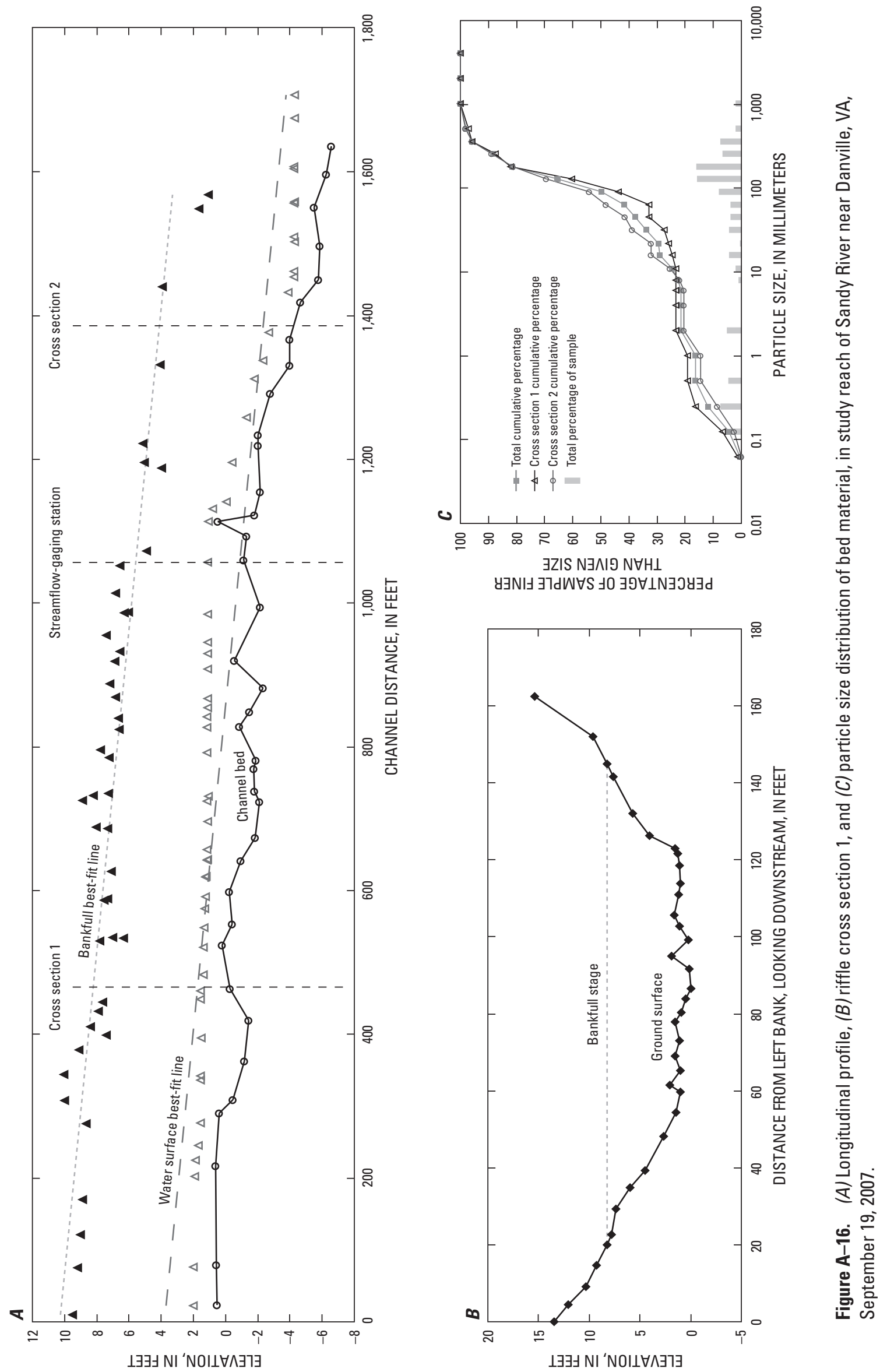


\section{Station 02075350}

Powells Creek near Turbeville, VA

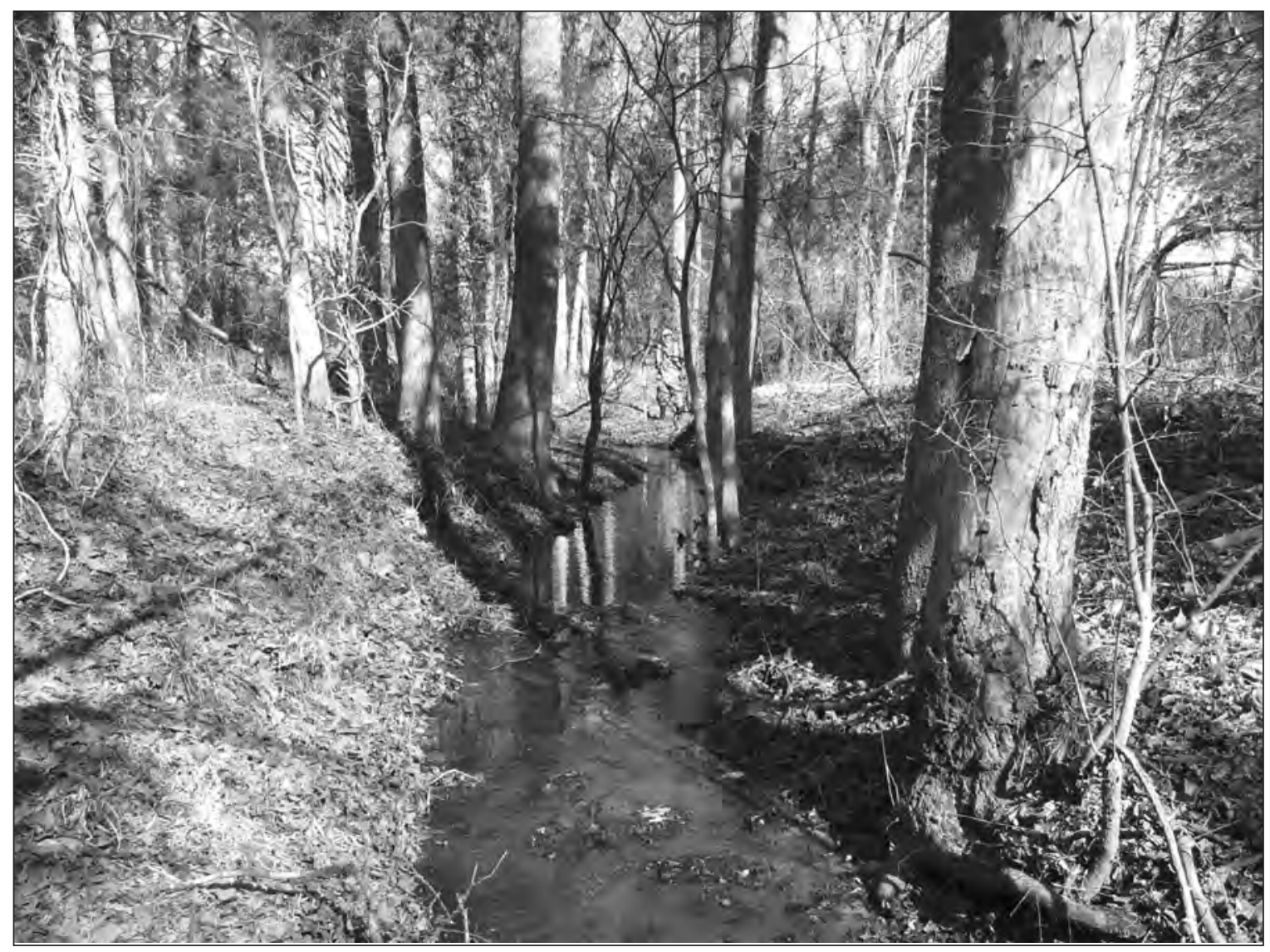

View looking upstream at reach for Powells Creek near Turbeville, VA.

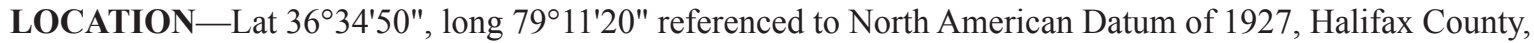
VA, Hydrologic Unit 03010104, at culvert on U.S. Highway 58, 0.8 mi upstream from mouth, 1.1 mi east of Halifax-Pittsylvania County line, and 8.8 mi southwest of Turbeville.

DRAINAGE AREA $-0.29 \mathrm{mi}^{2}$.

REMARKS - The watershed is 12.7 percent forested. The channel maintains a consistent geometry throughout the surveyed reach, consisting of gently sloping banks extending up to a nearly flat, densely vegetated floodplain on both banks. The primary bankfull features are depositional features on both banks. The bed is mostly sand and gravel. 

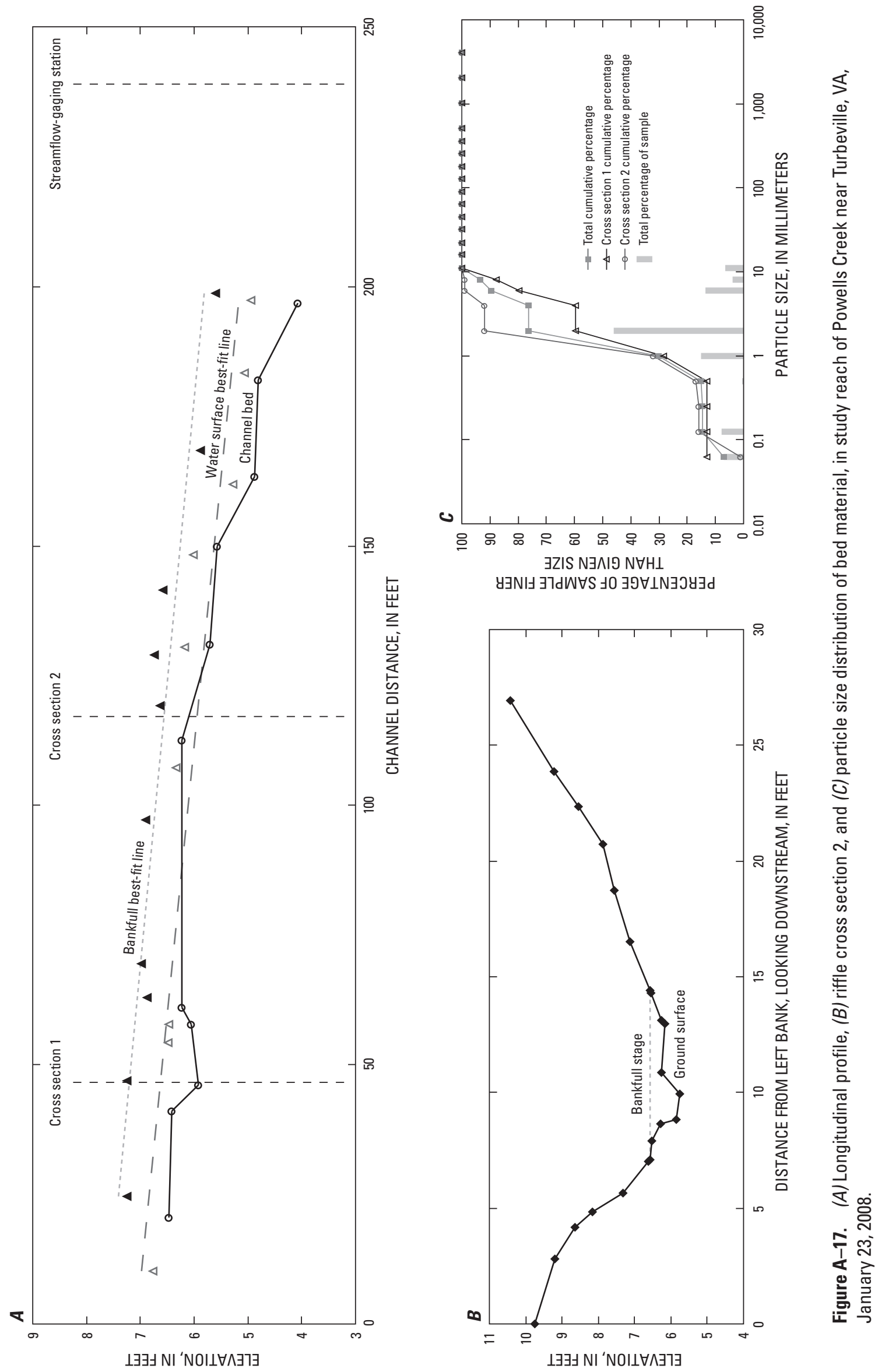
Manuscript approved for publication, September 18, 2009

Edited by Kay E. Hedrick

Layout by Caryl J. Wipperfurth

For more information concerning the research in this report, contact USGS Virginia Water Science Center

1730 East Parham Road

Richmond, VA 23228

Telephone: $804-261-2600$ or 1-800-684-1592

http://va.water.usgs.gov 
